\title{
Personality Traits as a Partial Explanation for Gender Wage Gaps and Glass Ceilings
}

\author{
Matthias Collischon ${ }^{a, b *}$ \\ ${ }^{a}$ Institut für Arbeitsmarkt- und Berufsforschung (IAB), Regensburger Strasse 100, 90478 Nuremberg, Germany \\ ${ }^{b}$ University of Erlangen-Nuremberg. Lange Gasse 20. 90403 Nuremberg. Germany
}

March 8, 2021

This paper is forthcoming in Research in Social Stratification and Mobility, doi: 10.1016/j.rssm.2021.100596.

\begin{abstract}
This paper investigates whether personality traits can explain glass ceilings (increasing gender wage gaps across the wage distribution). Using longitudinal survey data from Germany, I combine unconditional quantile regressions with wage gap decompositions to identify the effect of personality traits on gender gaps and investigate potential channels of the effect. The results suggest that the impact of personality traits on wage gaps increases across the wage distribution. Personality traits explain up to $14 \%$ of the overall gender wage gap at the top of the wage distribution and around 7-9\% at the mean. The effect is mostly driven by direct wage effects (potentially through productivity or bargaining behavior) of certain traits that differ between men and women, while access to jobs and discrimination of women based on personality traits play a minor role.
\end{abstract}

Keywords: non-cognitive skills, personality traits, unconditional quantile regression, gender wage gap, glass ceiling

JEL Codes: C21, J16, J31.

\footnotetext{
${ }^{*}$ Email address: matthias.collischon@fau.de (Matthias Collischon).
} 


\section{Introduction}

Increasing gender wage gaps across the wage distribution are present in many countries (see for example Christofides et al., 2013). However, the causes of gender wage gaps in general and variation of the gender wage differential across the wage distribution in particular - especially when they persist after accounting for (self-)selection into occupations and industries - are still puzzling. I investigate whether personality traits ${ }^{1}$ can explain variation in gender wage gaps across the wage distribution.

In this paper, I refer to increasing gender gaps across the wage distribution as glass ceilings. However, I would like to clarify, to avoid confusion, that in the literature, the term glass ceiling can refer to either gender differences in promotions between men and women (e.g. Maume, 1999) or to increasing gender wage gaps across the wage distribution (e.g. Cotter et al., 2001). Typically, the public discourse revolves around the former definition (e.g. The Guardian, 2011), whereas both definitions exist in the scientific literature. This paper relies on the latter definition.

Some existing studies (e.g. Mueller and Plug, 2006; Semykina and Linz, 2007; Fortin, 2008; Braakmann, 2009; Nyhus and Pons, 2012) examine the impact of personality traits on gender wage gaps. They find that these traits account for around $4 \%$ to $12 \%$ of mean gender wage gaps, conditional on covariates. Unfortunately, none of these studies investigates the impact of personality traits on glass ceilings.

However, a number of previous findings suggest that personality traits could be important pieces of the puzzle to explain glass ceilings in wages. Nandi and Nicoletti (2014) and Collischon (2020) show that the magnitude of the correlation of personality traits and wages increases across the wage distribution, arguing that e.g. individual wage bargaining and performance pay gain increasing importance for individual-level wage setting in high- compared to low-paid jobs.

Furthermore, the literature shows that women tend to do worse in competitive, mixed-sex

\footnotetext{
${ }^{1}$ For consistency, I solely use the term personality traits in this paper. The literature also often uses the term non-cognitive skills.
} 
situations (Azmat et al., 2016; Booth and Yamamura, 2018), shy away from competitive pay schemes that generally pay more (Heinz et al., 2016; McGee et al., 2015; Niederle and Vesterlund, 2007), fare worse in wage negotiations (Stuhlmacher and Walters, 1999) and obtain lower bonus payments (e.g. performance premia) than males (Card et al., 2016). Success in wage negotiations, risk aversion, and competitive behavior are likely manifestations of personality traits and, as discussed previously, potentially gain importance across the wage distribution. Taken together, these two strands of the literature thus strongly suggest that personality traits could play an important role in explaining glass ceilings.

This study contributes to the literature in three ways. First, I develop a theoretical framework to identify channels through which personality traits could matter for gender wage gaps in general and why they provide potential explanations for glass ceilings. Second, I use large scale-survey data from the German Socio-Economic Panel (SOEP) to test implications of the theoretical framework in the labor market. The SOEP contains measures of the five factor model of personality (also known as the big five), locus of control, positive and negative reciprocity and risk taking (Section 2.1 provides an overview on these concepts). I combine unconditional quantile regressions (UQRs, Firpo et al., 2009) with a decomposition method proposed by Fortin (2008) to estimate the impact of personality traits on gender wage gaps at different points of the wage distribution. Third, I discuss the degree to which not controlling for personality traits biases the results of classical gender wage gap studies that solely control for labor market characteristics.

Overall, I thus contribute to a more nuanced understanding of the connection between personality traits and gender wage gaps. However, I do not claim to identify causal effects of personality traits on wages because I cannot use truly exogenous variation in personality traits to estimate effects.

This paper is organized as follows: Section 2 provides theoretical considerations concerning gender differentials, personality traits, derives hypotheses towards the role of personality traits in explaining gender wage gap and discusses previous findings. Section 3 provides an overview 
on the data used in the analysis. Section 4 presents the econometric approach. Section 5 presents and discusses the results and various robustness tests. Section 6 concludes.

\section{Theoretical Background}

\subsection{Personality Constructs}

This section provides an overview on personality traits that are used throughout this paper. While personality traits in general encompasses a myriad of factors, the traits I investigate are well-established measures in the literature that were shown to correlate with labor market outcomes (e.g. Heineck and Anger, 2010) as well as to differ by gender (e.g. Nyhus and Pons, 2012). Thus, they provide potential explanations for gender wage gaps.

The big five personality traits are commonly used in the literature and are also part of this paper. The five factor model (McCrae and Costa, 2008) distinguishes five basic personality traits: extraversion, agreeableness, conscientiousness, neuroticism and openness to experience. Extraversion is related to social orientation. Agreeableness captures cooperative behavior. Conscientiousness measures planned (in contrast to spontaneous) behavior and neuroticism (sometimes referred to as emotional stability) relates to anxiety and being moody and openness to experience measures, for example, the degree of imagination and curiosity (Judge et al., 1999).

Another personality dimension commonly used is locus of control, which encompasses a spectrum from internal to external. External Locus of control refers to degree of perceived control over the events in one's life (Rotter, 1966). Individuals that score high on this scale are more likely to believe that they their lives are rather determined by chance than by their own actions, in contrast to individuals with an internal locus of control.

I also investigate the role of reciprocity, i.e. the degree to which individuals react cooperatively in response to friendly actions (positive reciprocity) and hostile in response to harmful actions (negative reciprocity) towards them (Fehr and Gächter, 2000). It is important to differentiate between the two facets, as individuals are more likely to punish harmful behavior than 
to reward friendly behavior (Charness and Rabin, 2002). Furthermore, I examine the role of the individual willingness to take risk (often referred to as risk taking in the remainder of this article) for gender wage gaps.

Lastly, I would like to stress that there are other aspects of personality, like for example individual preferences for work or for money that seem to matter for wages (e.g. Fortin, 2008). Unfortunately, due to data constraints in the empirical analysis, I cannot investigate further traits. However, the measures used in this paper should at least to some degree also capture unobserved differences if they correlate with the concepts presented.

\subsection{Personality Traits as Drivers of Productivity, Wage Bargaining and Job Choice}

This as well as the following section, against the backdrop of the personality traits presented previously in Section 2.1, derives hypotheses on channels through which these traits could potentially explain gender wage gaps. It relies on theoretical considerations on the connection on personality traits and wages as well as on previous literature on the correlation of personality traits and labor market outcomes.

Bowles et al. (2001) develop a framework in which personality traits influence how strongly individuals react to incentives. They argue that personality traits affect the costs of eliciting effort. Thus, ceteris paribus, individuals with specific personality traits which lower these (mental) costs are more productive than their counterparts with unfavorable personality traits and therefore receive higher wages.

Therefore, certain personality traits could affect productivity and, if these differ systematically between men and women, could thus affect gender wage gaps. The literature shows that men and women differ in conscientiousness (with women being on average more conscientious) and neuroticism (with men scoring lower on the neuroticism-scale, Heineck and Anger e.g. 2010), traits that both affect productivity ${ }^{2}$ (Cubel et al., 2016). Additionally, openness to expe-

\footnotetext{
${ }^{2}$ In the case of Cubel et al. (2016), productivity is measured as the performance of adding five digit arrays for twenty, which requires e.g. concentration and perseverance under time pressure, skills that are also required in the labor market.
} 
rience could affect productivity as it measures for example creativity, a characteristic that could be rewarded monetarily (Heineck, 2011) and that women typically score higher on (Rantanen et al., 2007). Reciprocity could also affect individual productivity, as Fehr and Gächter (2000) suggest that individuals that score high on reciprocity are more likely to elicit higher effort in response to incentives, thus tying reciprocity closely to the theoretical framework of Bowles et al. (2001). Furthermore, studies typically show women to be more reciprocal compared to men (for an overview see Croson and Gneezy, 2009). Overall, neuroticism, conscientiousness, openness to experience and reciprocity are traits that likely affect wages through productivity and that differ by gender. Thus, they could potentially contribute to the gender wage gap.

Furthermore, personality traits could also affect wage bargaining behavior, as for example suggested by Nandi and Nicoletti (2014) and Mueller and Plug (2006). In this case, the effects could be driven by personality traits such as agreeableness and external locus of control, traits that both correlate negatively with wages (Heineck and Anger, 2010) and that women typically score higher on (e.g. Heineck and Anger, 2010). Agreeable individuals or individuals with a more external locus of control could be more likely to give in to relatively low offer or be less demanding overall. Additionally, risk taking behavior could play into wage bargaining. For example, less risk aversion is associated with a higher probability of working in a variable pay scheme (Caroli and Garcia-Penalosa, 2002), which can also be an outcome of wage negotiations. This could explain findings from the literature: men and women differ in the outcomes of wage negotiations (e.g. Dittrich et al., 2014), with women being disadvantaged. Combining these findings suggests that personality traits could also affect the gender wage gap through wage bargaining.

In both cases, personality traits as drivers of productivity or wage bargaining behavior, gender wage differences due to personality traits should arise through mean differences in these traits, with males likely being advantaged, e.g. by, on average, being less agreeable. However, this line of reasoning predicts no differences in the monetary returns to the respective traits by gender, i.e. it predicts no difference in the correlation of the respective traits and wages by 
gender.

Furthermore, personality traits correlate with job choice (John and Thomsen, 2014). For example, manually working men are on average less extravert. Thus, differences in personality traits could be a cause for men to sort in higher-paying occupations compared to women. This could also be a cause for gender wage gaps and glass ceilings if personality traits lead women to choose or stay in low-paying occupations and/or men to sort into high-paying jobs. As John and Thomsen (2014) show, occupational choice can potentially be related to a variety of personality traits. Thus, for this channels, potentially all traits mentioned in Section 2.1 could matter. In this case, I expect the contribution of personality traits to gender wage gaps to decline when controlling for occupation and industry in the empirical model.

\subsection{Discrimination and Gendered Expectations}

Explanations for gender wage differentials often rely on discrimination theories (for an overview over various explanations see Blau and Kahn, 2017). Taste-based discrimination Becker (1971) is a classical explanation for gender wage differentials. Becker (1971) argues that employers discriminate against females through wages if male employees prefer working with males and thus demand a premium for working with females. Additionally, employers themselves could exhibit a taste for discrimination and thus discriminate against women in terms of wages or employment. The pollution theory of discrimination (Goldin, 2014) argues, comparably, that males want to prevent females from "polluting" the status of their occupation by introducing female values. Thus, males demand compensations for working with females. Comparable sociological theories (e.g. Ridgeway, 2001) argue that gender stereotypes incorporate status beliefs and that males are regarded as more competent. These beliefs justify gender wage differentials.

Against the backdrop of discrimination theories, personality traits could matter in two ways. First, discrimination could not only arise from employees wanting to work with colleagues that are of the same gender, but also conform to gender role expectations that are related to personality traits. Gender norms and roles shape expectations towards typical masculine and feminine 
behavior, with e.g. competitiveness being considered masculine and associated with certain personality traits like low agreeableness (Williams et al., 1999). Feminine behavior in contrast typically encompasses being nice and females could be penalized for not following this norm (Rudman and Glick, 2001), which could for example show in a low score in agreeableness or high scores in the willingness to take risks. Thus, it could be the case that males and females are rewarded differently in terms of wages for the same personality trait due to gendered expectations.

Second, discrimination based on personality traits could also affect gender wage gaps indirectly, through selection into jobs. For example, the entrance into certain occupations could be subject to discrimination due to personality traits. In this case, mean differences in certain traits between men and women could lead to occupational sorting patterns and, through this channel, contribute to gender wage gaps. Thus, if personality traits lead to gender wage gaps because gender differences in these traits lead to men and women choosing different occupations or if there is discrimination based on personality traits that correlate with gender (e.g., in the sense of the pollution theory Goldin 2014), I expect the share of the wage gap explained by personality traits to decline when controlling for occupations and industries. This hypothesis does not imply differences in the returns to personality traits between men and women.

All channels previously presented could vary across the wage distribution. Potentially, there is more room for productivity pay higher up the wage distribution, because wage-setting in these cases is less restricted by collective agreements or labor protection laws. Lower degrees of regulation, however, could also lead to more room for discrimination. Furthermore, personality traits leading to self-selection into certain high- or low-paying occupations and industries as well as discrimination in the access to certain jobs could also lead to glass ceilings arising from differences in personality traits.

Table 1 provides an overview on the channels identified in this section and how they could play out empirically in the analysis. The table shows that certain potential channels play out in the same manner and a specific identification (e.g. showing that agreeableness solely affects 
wage bargaining) is, unfortunately, hardly possible. However, it is still possible to disentangle whether personality traits (i) directly affect wage gaps (either through bargaining or productivity), (ii) affect wage gaps through access to jobs (which implies either self-selection or discrimination in the access to certain jobs through personality traits) or (iii) if there is discrimination in the returns to certain traits.

\subsection{Previous Findings}

Several studies investigate the connection between personality traits and gender wage gaps at the mean. Of the previously mentioned concepts, Mueller and Plug (2006), Braakmann (2009), Nyhus and Pons (2012) and Risse et al. (2018) investigate the impact of the big five on gender wage gaps. They generally find that gender differences in agreeableness and, in some cases, neuroticism, contribute to gender gaps in terms of differences in endowments, i.e. men scoring more favorable on the respective scales compared to females. However, differential returns to these traits hardly seem to matter.

Semykina and Linz (2007), Braakmann (2009) and Nyhus and Pons (2012) investigate the role of locus of control for gender wage gaps and, suprinsingly and in contrast to expectations derived in the previous section, find it to hardly matter for gender wage gaps both in terms of endowments as well as differential returns. Braakmann (2009) furthermore investigates the role of reciprocity and risk taking for gender gaps and finds that, net of socioeconomic control variables, reciprocity (neither positive nor negative) does not affect gender wage gaps, although positive reciprocity correlates significantly with wages. However, because positive reciprocity does not differ between men and women in terms of endowments, it does not affect gender wage gaps. With regards to risk taking, dependent on the reference wage structure used in the decomposition, gender differences in risk taking explain a small share of the overall gender wage gap.

Overall, the literature shows that personality traits account for around 5-10\% of the overall gender wage gap at the mean.The reduction in gender gaps is mostly driven by differences in 
endowments with men having more favorable characteristics with regards to wages (e.g lower degrees of agreeableness, Mueller and Plug, 2006). This is consistent with the notion that personalty traits affect either productivity at work or bargaining behavior.

In contrast, gender differences in returns hardly seem to matter: they can only explain around $0.5 \%$ of the overall gap (Nyhus and Pons, 2012). Thus, discrimination based on gendered expectations and deviations from gender-specific behavior seem to play a minor role.

Gender differences in occupational choice due to personality traits and the role of personality traits as criteria for discrimination in the entrance into specific occupations seem to be minor. Semykina and Linz (2007) and Mueller and Plug (2006) both show models with and without controlling for industry and job characteristics and find only modest changes in the impact of personality traits on gender wage gaps when introducing these controls.

The literature has several blind spots. First, most studies suffer from small sample sizes which is especially problematic in the case of personality traits where classical measurement error is likely to occur and thus lead to imprecise estimates (e.g Mueller and Plug, 2006).

Second, no study in the literature investigates the impact of personality traits on gender gaps across the wage distribution, even though personality traits seem to be of a higher importance for high-wage employees (Collischon, 2020) and gender gaps also increase across the wage distribution in many countries (Christofides et al., 2013). If for example the room for discrimination or wage bargaining increases across the wage distribution, personality traits could lead to glass ceilings. This article sheds light on these blind spots.

\section{Data \& Descriptives}

\subsection{Estimation Sample}

The analysis is based on data from the German Socio-Economic Panel (SOEP, Wagner and Frick, 2007) from 1991 to 2015. As I am interested in gender wage gaps across the wage distribution, the outcome of interest is the individual hourly wage, which is calculated from 
contractual weekly working hours ${ }^{3}$ and gross monthly earnings. In the main analysis, I focus on employees aged 19 to 65 .

Figure 1 plots the hourly wages by gender. As can be seen and as expected, males earn on average higher hourly wages compared to females. On average, males report hourly wages of EUR19.44, while females report hourly wages of EUR14.42, implying an average wage gap of $25.82 \%$. Furthermore, around $64 \%$ of the individuals in the bottom decile of the overall wage distribution are female, compared to around $24 \%$ at the highest decile. Thus, the data, unconditional on covariates, implies a substantial gender wage gap at the mean as well as a substantial under-representation of women in high-paying jobs. For the analysis, in line with the literature (e.g. Mueller and Plug, 2006) on wage gaps, I use the natural logarithm of hourly wages as the outcome.

The SOEP contains a large set of potential control variables. In the main analysis, I control for the respondent's age (and age squared), the CASMIN-classification for education (which allows to account for the specifics of the German educational system in detail, Brauns et al., 2003), marital status (as an indicator for being married), whether a child under the age of 16 lives in the household, indicator variables for establishment size of the employer, migration background (measured with two indicator variables; one for direct and one for indirect immigration background), full time employment experience, part time employment experience, unemployment experience, job tenure, whether the employee works for a public employer, an indicator for living in East Germany and survey year dummies. Table 2 shows sample descriptives by gender. ${ }^{4}$

Furthermore, to investigate whether selection into specific occupations or industries moderates the impact of personality traits on wages, I additionally control for occupations (as 2digit-ISCO codes) and industries (as NACE top groups) in a further step. ${ }^{5}$. Overall, the main

\footnotetext{
${ }^{3}$ The SOEP also contains information on actual working hours per week. However, using this information as an alternative measure for working time does not significantly affect the results.

${ }^{4}$ Additionally, Appendix Table A1 shows sample desciptives of covariates in Panel B at different points in the overall wage distribution.

${ }^{5}$ Appendix Tables A2 and A3 show the distribution of occupations and industries by gender.
} 
estimation sample consists of 152,777 observations for 20,008 individuals.

\subsection{Personality Traits in the Data}

The SOEP includes measures of personality traits that I presented in Section 2.1. The survey contains measures for the big five personality traits, derived from the five factor model (McCrae and Costa, 2008), distinguishing between extraversion, agreeableness, conscientiousness, neuroticism and openness to experience. The big five are survey with 15 items (with 3 question for each trait, Dehne and Schupp, 2007).

Furthermore, the SOEP contains information on external locus of control (Rotter, 1966), measured with 8 items, positive and negative reciprocity with 3 items each, and risk taking behavior on a self-rated 11-point-scale.

In line with previous studies (Collischon, 2020; Heineck and Anger, 2010), I construct additive indices for each trait. ${ }^{6}$ The scales of personality in the data are well-established and have been used in previous publications (e.g. Heineck and Anger, 2010; Heineck, 2011; Risse et al., 2018).

Because not every survey wave contains all items, I follow the imputation method suggested by Heineck and Anger (2010). Gaps due to missing questions in the survey are filled by imputing the previous or next (whichever is closer to the survey year) valid response. Additionally, I regress the respective personality items on age and age squared because personality traits are largely stable, but can change with age (Cobb-Clark and Schurer, 2012). I use the residuals from these regressions as measures of personality traits that are cleared of age effects and standardize all scales by dividing the respective traits by their sample specific standard deviation.

Personality traits would be "bad" explanatory variables if they are endogenous. For example, women could experience discrimination in the labor market which in turn leads to changes in their personality traits. However, previous studies show that personality traits are fairly sta-

\footnotetext{
${ }^{6}$ Appendix Table A4 shows a detailed overview on the questionnaire items for the personality traits in the data and their reliability ratios.
} 
ble (Elkins et al., 2017) and that changes in personality traits are hardly related to labor market events (Anger et al., 2017; Cobb-Clark and Schurer, 2013).

Figure 2 shows the means of standardized personality traits across the distribution of wages, measured in decile steps, with the big five traits in Panel (a) and locus of control, reciprocity and risk taking in Panel (b). Due to the standardization, the overall sample means are close to zero. Overall, the results show that especially individuals in the higher parts of the wage distribution report lower scores in agreeableness, neuroticism, external locus of control, as well as higher scores in risk taking and openness to experience, compared to the overall average. This is first descriptive evidence that personality traits differ systematically across the wage distribution.

Additionally, Table 3 shows the means of the personality measures by gender as well as by whether the respondent works in a managerial occupation ${ }^{7}$. With regards to gender differences (displayed in columns 1 to 3 ), the table reports statistically significant gender differences in all personality traits in the SOEP. Generally, men exhibit characteristics that could be positively related to wages (as for example suggested by Figure 2), like lower degrees of external locus of control, neuroticism, agreeableness, and a higher degree of risk taking. This indicates that personality traits could be a reason for gender wage gaps.

Furthermore, Table 3 also shows differences in personality traits conditional on whether the respondent works in a managerial occupation in columns 4 to 6 . As displayed, managers report on average lower scores on agreeableness, neuroticism, and external locus of control compared to other employees, as well as higher scores on openness to experience and risk taking. Furthermore, managers earn drastically higher wages than non-managers and only $26.9 \%$ of managers are female, in contrast to $49.2 \%$ of employees in other occupations. Taken together, these first descriptive results show that there are significant differences between men and women with regards to personality traits, as well as between managers and non-managers, with managers being less likely to be female and earn higher wages than other occupations. This supports the notion that personality traits could be an explanation for gender wage gaps and that selection

\footnotetext{
${ }^{7}$ Defined as being either a corporate manager or a manager in a small enterprise
} 
into highly-paid occupations due to personality could also contribute to gender wage gaps. ${ }^{8}$ Thus, in the next step, I investigate the exact role of personality traits in explaining glass ceilings with gender wage gap decompositions.

\section{Econometric Method}

\subsection{Unconditional Quantile Regression}

I use unconditional quantile regressions (UQR) to investigate gender wage gaps and the impact of personality traits on them across the wage distribution. The UQR essentially performs an OLS-regression on the recentered influence function (RIF) of a statistic of interest of a dependent variable $Y$ (Firpo et al., 2009). In the case of this paper, the dependent variable is the natural logarithm of the hourly wage. Influence functions are used to asses the marginal impact of particular observations on a statistic of interest. In this paper, I use the RIF-concept to investigate specific quantiles in this context. The influence function of a quantile $\tau$ can be written as:

$$
\operatorname{IF}\left(Y, Q_{\tau}\right)=\frac{\tau-\mathbb{I}\left\{Y \leq Q_{\tau}\right\}}{f_{y}\left(Q_{\tau}\right)}
$$

where $\mathbb{I}\left\{Y \leq Q_{\tau}\right\}$ is an indicator function to weight the quantile, $f_{y}$ is the density function of the marginal distribution at $Q_{\tau}$. The RIF-concept extends this approach by adding the quantile of choice $Q_{\tau}$ to the influence function:

$$
\operatorname{RIF}\left(Y, Q_{\tau}\right)=Q_{\tau}+\frac{\tau-\mathbb{I}\left\{Y \leq Q_{\tau}\right\}}{f_{y}\left(Q_{\tau}\right)}
$$

The RIF is then used as the dependent variable in an OLS-regression. UQR estimates marginal effects of regressors on a quantile $\tau$ of interest while OLS estimates marginal effects

\footnotetext{
${ }^{8}$ Further descriptive evidence in Appendix Table A1, Panel A supports this notion: individuals in the lowest decile of wages are more likely to be female and also more likely to exhibit an above-average (compared to the overall sample mean) score in external locus of control. In contrast, individuals at the highest decile of wages are less likely to be female and also report below-average scores in agreeableness and locus of control.
} 
of regressors at the mean.

The alternative to using UQR would be using the classical (conditional) quantile regression (CQR, Koenker and Bassett, 1978) which is based on conditional quantiles. CQR estimates marginal effects of regressors of interest on the conditional quantiles (conditional on the covariates included in the model) of interest. In contrast, UQR uses the unconditional distribution of $y$, independent of covariates included in the regression model. ${ }^{9}$

Concerning the research question this paper investigates, UQR is preferable to CQR, because the definitions of low- and high-wage employees in a CQR-framework depend on the covariates included in the estimation. However, I am interested in investigating glass ceilings for women in terms of overall low- and high-wage employees, independent of the covariates included in the model. Therefore, I rely on UQR in the empirical estimation.

\subsection{Decomposition of Wage Differentials}

I combine UQR with a Kitagawa-Oaxaca-Blinder (KOB; Kitagawa, 1955; Blinder, 1973; Oaxaca, 1973) style decomposition to assess the contribution of personality traits to gender wage gaps. In addition to a decomposition at the mean, I run decompositions on the unconditional quantiles of interest obtained from UQR. In the classical KOB-decomposition, the wage gaps depend on the choice of the reference group (which can drastically alter the results, e.g. Braakmann 2009), i.e. the KOB-decomposition assumes that the wage structure of either males or females is non-discriminatory and thus altering the reference wage structure affects the results. This problem is known as the index number problem (Oaxaca, 1973).

Neumark (1988) and Oaxaca and Ransom (1994) provide solutions to this issue by proposing a method that additionally uses a pooled regression without a gender dummy to obtain wage gaps that are independent of the reference wage structure. Their methods are widely used in the literature (e.g. Christofides et al., 2013; Semykina and Linz, 2007). However, this method is likely to underestimate unexplained wage gaps, because coefficients in the pooled estimation

\footnotetext{
${ }^{9}$ Killewald and Bearak (2014) provide a comprehensive comparison of both methods.
} 
could capture gender differences due to omission of a gender indicator in the estimation (Elder et al., 2010; Fortin, 2008).

To account for this problem, I use the pooled decomposition proposed by Fortin (2008) to decompose gender wage gaps at specific quantiles of interest (Fortin et al., 2011; henceforth called FFL-decomposition). This method obtains the unexplained wage gap from a pooled regression with a group indicator variable and uses the coefficient of this dummy variable as a measure for the unexplained wage gap and thus circumvents the problems of the Oaxaca and Ransom (1994) decomposition. ${ }^{10}$

The case of a wage decomposition at the mean (with the natural logarithm of wages (lnw) as the outcome of interest) with males as the omitted group in the pooled regression can be written as:

$$
\overline{\operatorname{lnw_{m}}}-\overline{\operatorname{lnw_{f}}}=\Delta X \hat{\beta}_{p}+\left[\bar{X}_{m}\left(\hat{\beta}_{m}-\hat{\beta}_{p}\right)+\left(\hat{\beta}_{0 m}-\hat{\beta}_{0 p}\right)\right]-\left[\bar{X}_{f}\left(\hat{\beta}_{f}-\hat{\beta}_{p}\right)+\left(\hat{\beta}_{0 f}-\hat{\beta}_{0 p}\right)\right]
$$

where $\hat{\beta}$ are the estimated coefficients and $\hat{\beta}_{0}$ are the constants from pooled $(p)$ and genderspecific ( $m$ and $f$ ) regressions. $X$ is a set of regressors. $\Delta X \hat{\beta}_{p}$ is the difference in explained characteristics. The terms in brackets are used to assign proportions of the unexplained gap to variables in $X$. The decomposition can easily be extended to any statistic of the dependent variable of interest by using the respective RIF as the outcome of interest.

In the analysis, I estimate decompositions at the mean, median, 10th and 90th percentile to see whether personality traits can explain gender wage gaps for low-, high- and average-paid employees. The choice of these points in the wage distribution is arbitrary, but using other points of the distribution (e.g. the 25 th or 75 th percentile) does not change the overall findings in terms of the importance of personality traits for gender wage gaps. I use cluster-robust standard errors in all estimations to account for the panel structure of the data.

The decomposition method allows for a detailed decomposition of wage differentials thus

\footnotetext{
${ }^{10}$ Fortin et al. (2011) provide a comprehensive overview over various decomposition methods for further reading.
} 
showing how certain variables contribute to the explained (due to differences in means) and unexplained (due to differences in the returns to certain characteristics) wage gaps. Thus, assessing the contribution of specific personality traits to gender wage differentials is possible, which allows to identify channels of the effects. ${ }^{11}$ However, the impact of personality traits on wage gaps derived from the detailed decomposition is not necessarily equal to the overall change in unexplained wage gaps because other control variables (e.g. occupation) may implicitly control for the effect of personality traits if they are correlated. Thus, to additionally assess how large the bias in gender wage gap estimations that do not account for personality traits is, I will also investigate the difference in the contribution of personality traits to gender wage gaps with and without controlling for personality traits.

\section{Results}

\subsection{Results without controlling for occupations \& industries}

In this section, I present and discuss the results of the decomposition analyses. In all estimations, I report the raw gap (the unconditional wage difference between males and females at a certain point in the wage distribution), the explained gap (the difference that can be explained by observable characteristics), the unexplained gap (the remaining share not accounted for by covariates) and detailed decompositions for both parts. The detailed decomposition of the explained part allows me to precisely show the impact of mean differences in certain traits on the gender gap, while the detailed decomposition of the unexplained gap allows to make statements about differences in returns to certain traits, i.e. to investigate whether females are penalized for certain traits compared to males. This provides the opportunity to investigate the channels proposed in Table 1.

I begin by investigating the impact of personality traits on wage gaps without controlling

\footnotetext{
${ }^{11}$ In the case of the contribution of certain variables to unexplained wage gaps, note that linear transformations of the respective variables can affect the contribution to the unexplained wage gap, because this can shift a part of the effect from the differences in the constant between the genders to the variables of interest (Jann, 2008; Jones and Kelley, 1984). However, re-scaling the measures for personality traits, e.g. by adding or subtracting 0.5 standard deviations to the variables of interest hardly changes the results.
} 
for occupation and industry. This way, the estimations capture the full effect of personality traits on gender gaps, because occupations and industries are closely related to wages and access to occupations and industries could as well be restricted due to discrimination based on personality traits or matter due to self-selection. Columns 1 to 4 of Table 4, Panel (A) show the results of the estimations without controlling for personality traits. In line with the literature (Collischon, 2019), the results show a glass ceiling, i.e. an increasing unexplained gender wage gap across the wage distribution. Table 4, Panel B adds personality traits to the estimations. ${ }^{12}$ Overall, unexplained gender wage gaps remain constant or decrease in all estimations when adding personality traits, as expected.

Personality traits explain around $7 \%^{13}$ of the mean gender wage gap. ${ }^{14}$ The findings in this specification are comparable to previous studies by Braakmann (2009), Mueller and Plug (2006) and Semykina and Linz (2007) who find that personality traits explain between 3\% to $13.6 \%$ of the overall gender wage gap at the mean.

The results suggest substantial variation of the explanatory contribution of personality traits across the wage distribution: the share of the overall wage gap explained by personality traits increases from $1.9 \%$ (at the 10th percentile) to $11.7 \%$ (at the 90 th percentile). Thus, the results suggest, in line with expectations, that (i) personality traits provide an explanation for gender wage gaps and (ii) that the importance of personality traits for gender wage gaps increases along the wage distribution.

Investigating whether personality traits contribute to gender wage gaps in terms of endowments or differential returns is insightful to investigate the mechanisms at play, as hypothesized in Section 2 and Table 1. The results (displayed in the lower part of Table 4) show significant gender differences in endowments. Conditional on covariates, especially agreeableness, neuroticism, locus of control, personality traits that are typically penalized in terms of wages,

\footnotetext{
${ }^{12}$ Additionally, Appendix Tables A5 to A8 show the regression results for this specification.

${ }^{13}$ I compute the share of personality traits on wages by summarizing the contribution of these traits to explained and unexplained gaps and dividing the result by the raw wage gap.

${ }^{14}$ For comparison, personality traits are - at the mean - half as important as job experience variables in the US which explain $14.1 \%$ to $15.9 \%$ of the gap in 2010 (Blau and Kahn, 2017).
} 
contribute to the gender wage gap due to more favorable endowments of men. Openness to experience, in contrast, works in favor of women but cannot offset the disadvantages generated through other traits. The findings are mostly in line with the literature, e.g. Braakmann (2009) and Nyhus and Pons (2012) and indicate that gender differences in productivity and bargaining behavior likely contribute to gender wage gaps. Unfortunately, it is not possible to further disentangle both mechanisms as personality traits like neuroticism and agreeableness could work through both channels. As expected, the effects vary across the wage distribution: the impact of agreeableness, neuroticism as well as risk taking increases across the wage distribution. Interestingly, gender differences in risk taking work in favor of men at the upper parts of the wage distribution, but work in favor of women at the 10th percentile. This suggests that higher paying jobs could reward more risky behavior, whereas this is not the case for low-paying jobs (that are e.g. likely to consist of relatively routine tasks where risk aversion could be preferable).

Differential returns seem to contribute to gender wage gaps in some cases (e.g. with regards to locus of control and agreeableness), but their overall contribution to gender wage gaps is minor compared to effect of differences in endowments, which is comparable to the findings of Nyhus and Pons (2012) who find that differences in returns account for only $0.5 \%$ of the mean raw earnings differential between men and women (0.7\% at the mean in my case). Nevertheless, different returns for men and women still seem to have increasing effects across the wage distribution. For example, differences in returns to personality traits contribute $1 \%$ to the overall wage gap at the 10th percentile of wages. This share increases to $1.6 \%$ at the 90th percentile. Figure 3 plots the decomposition results with the contribution of personality traits to explained and unexplained gaps and shows that personality traits hardly contribute especially to unexplained gaps in any case. Thus, concerning channels, discrimination due to behavior that does not conform gender norms hardly contributes to gender wage gaps compared to the other channels.

I also investigate the magnitude of the bias that arises from not accounting for personality traits and thus to see how biased previous studies are. The impact of personality traits on 
unexplained gender gaps is only significant at the 90th percentile. There is also a difference between the overall contribution of personality traits to the gender wage gap (which is e.g. 2 $\log$ points in Germany at the mean, or $7 \%$ of the overall gender wage gap) compared to the reduction in the unexplained gender wage gap (which is $1.4 \log$ points in this case, or $5 \%$ of the overall gender wage gap). This suggests that the role of personality traits as omitted variables in classical gender wage gap estimations is limited, most likely because their effects are captured by other covariates.

\subsection{Accounting for occupations \& industries}

Next, I account for sorting mechanisms and discrimination in the access to occupations and industries and solely investigate the direct impact of personality traits on wage differentials within industries and occupations. Columns 5 to 8 of Table 4 display the results of the FFLdecompositions controlling for occupation and industry. Panel A shows the results without accounting for personality traits. Interestingly, controlling for occupation and industry does not significantly reduce the gender wage gap at any point investigated. However, this finding is in line with previous studies for Germany (Hinz and Gartner, 2005).

Panel B of Table 4, columns 5 to 8 shows the results conditional on personality traits. Personality traits still explain a small share of the gender wage gap, as shown in the detailed decomposition. ${ }^{15}$ The overall reduction in gender wage gaps is smaller, but still comparable to the estimations without accounting for sorting mechanisms. However, the contribution of personality traits to wage gaps decreases to a maximum of $10 \%$ (at the 90 th percentile). This effect is mostly driven by smaller explanatory power of endowments with personality traits for gender wage gaps. For example, the effects of agreeableness, locus of control and neuroticism decrease slightly across the wage distribution when controlling for occupation and industry. This indicates that personality traits partly contribute to gender gaps through sorting into certain occupations and industries or discrimination in terms of access to certain jobs, but this channels

\footnotetext{
${ }^{15}$ Appendix Tables A9 to A12 show the corresponding regression results.
} 
still seems relatively minor compared to the more direct impact of personality traits on wages through bargaining or productivity.

Figure 3, Panel B shows the decomposition results across the wage distribution, including controls for industry and occupation. Overall, the graphs show that differences in returns to certain traits (the contributions to unexplained wage differentials) do hardly contribute to gender wage gaps in any case.

\subsection{Accounting for Sample Selection}

Personality traits could not only affect productivity and the probability to work in certain jobs, but also the decision to work at all. For example, females' overall higher degrees of neuroticism could lead to a higher proportion of females that drop out from the labor market compared to males. This could bias the results of the wage gap analysis if the norms concerning labor market participation differ by gender, leading e.g. to men that score high on neuroticism to work, because male labor market participation is the norm while females that score high on neuroticism drop out of the labor market due to less social pressure to work. In this case, analyses with data just for the working population might suffer from sample selection bias.

Potential solutions to this problem are using the Heckman (1979) approach to account for sample selection or setting the wages of non-working individuals to 0 instead of missing values. However, finding truly exogenous instruments for the Heckman approach is difficult and assuming that the potential wage rate of non-working individuals is 0 is hardly realistic. I propose using the means of the wages in the prior and subsequent years around the missing value as the potential wage rate if the individual worked. This way, I should at least considerably reduce biases through dropping out of the labor force due to relatively low wages.

I impute missing wage information with the mean wages from the previous and consecutive two years. If these are not fully observed for the respective individuals, I use just the previous and consecutive year. If these are also missing, I use the consecutive or previous year to impute the hourly wage rate. I then correct wages by the consumer price indices obtained from the 
World Bank ${ }^{16}$. I use the natural logarithm of the hourly wages obtained this way as dependent variables in the estimation. I solely control for education, age, age squared, marriage, children in the household and survey year dummies. Thus, with this minimal set of controls that is available for all individuals and the correction for sample selection, the estimations should yield an upper bound for the overall impact of personality on gender wage gaps.

Table 4 columns 9 to 12 and Figure 3, Panel C show the results. Overall the differences between the estimations with and without accounting for selection are modest, in line with previous studies (Olivetti and Petrongolo, 2008). ${ }^{17}$ When accounting for sample selection and just a minimal set of controls, personality traits explain no more than a maximum of $14.7 \%$ of the gender wage gap (in this case at the 90th percentile).

Overall, all three specifications show moderate, but nevertheless non-negligible effects of personality traits on gender wage gaps. Furthermore, the impact of personality traits on wage gaps increases across the wage distribution. Figure 4 shows the relative share of wage gaps explained by personality traits for the specifications discussed previously. In all cases, the impact of personality traits on wage gaps increases across the wage distribution.

\subsection{Robustness Tests}

I run various checks to test the robustness of the findings. The results are reported in Table 5. All estimations include the full set of control variables, as described in the text. In the robustness checks, I abstain from controlling for occupation and industry to estimate the upper bound of the impact of personality traits on the gender wage gap. However, like in the main results, including occupation and industry controls in these estimations does not meaningfully affect the results. For brevity, I solely report unexplained gender wage gaps with and without accounting for personality traits.

First, I investigate whether personality traits have a non-linear impact on the gender wage

\footnotetext{
${ }^{16}$ Obtained from: https: / / data.worldbank.org/indicator/FP. CPI . TOTL.

${ }^{17}$ Appendix Tables A13 to A16 show the regression results from the estimations used in the decompositions.
} 
gap. In line with Mueller and Plug (2006) and Heineck and Anger (2010), I construct indicator variables from the reported scores that measure whether a respondent is in the top or bottom quartile of the distribution of a certain personality trait. Table 5, Panel A shows the results. Compared to the baseline, the results hardly change.

Second, because personality traits can change with age (Costa and McCrae, 1994), I restricted the estimation samples to individuals aged 30 to 55 (Table 5, Panel B) to decrease the potential remaining problem of reverse causality. Interestingly, in this specification, the unexplained gender wage gap at the 10th percentile increases drastically compared to the baseline results. This finding suggests that especially younger or older employees can explain the wage gap that even works in favor of women in the baseline specification. This could suggest that especially female workers in these age categories are positively selected and earn, net of controls, higher wages compared to their male counterparts. However, the results regarding the impact of personality traits hardly change compared to the baseline findings.

Third, personality traits could have more pronounced connections to wages for full time employees (Table 5, Panel C). Potentially, employers are better informed about the personality traits of their employees if they work full time and are thus able to reward or penalize certain traits. The findings for full time employees in Germany exhibit a relatively constant wage differential across the wage distribution. However, the contribution of personality traits in terms of a reduction of the previously unexplained gap remains largely the same as in the baseline results.

Fourth, to account for the sampling characteristics of the survey, I repeat the main analysis using the survey weights provided in the SOEP.$^{18}$ Overall, the results do not change compared to the baseline results which is hardly surprising, because a large share of the bias potentially induced by the sampling should be captured by the control variables included in the models (Solon et al., 2015).

\footnotetext{
${ }^{18}$ I use longitudinal weights in this case to account for potentially selective panel attrition. However, using cross-sectional weights leads to the same results.
} 
Fifth, I use the Heckman (1979) approach as an alternative way to tackle sample selection (Table 5, Panel E). I use parental education (as a dummy variable indicating if mother and/or father have obtained a college degree) as the instrument for selection into the labor market, in line with the literature (Heineck and Anger, 2010). I additionally control for gender, survey year, marital status, migration background, the presence of a child in the household, age and age squared in the selection term. While the estimation results show changes in the gender wage gaps, the contribution of personality traits is very similar to the baseline results. However, it is questionable whether parental education is truly an exogenous instrument for labor market participation.

As an additional check for the generalizability and sensitivity of the conclusions of the analysis with the SOEP, I repeat the estimations with data for the UK (using the UKHLS which survey the big five in the same manner as the SOEP) and Australia (with the HILDA which contains measures for the big five, with a more detailed scale than the SOEP, as well as a measure for locus of control). The results of these analyses are available in Online Appendix B. Overall, the results largely mirror the results from the SOEP. Personality traits explain around $7-9 \%$ at the mean in both countries. The estimations also show that the impact of personality traits on the gender wage gap increases across the wage distribution, to $12 \%(13.7 \%)$ at the 90 th percentile in Australia (in the UK). Like in the SOEP, differential returns by gender do hardly contribute to gender wage gaps. Furthermore, controlling for occupations and industries hardly affects the results. Thus, overall, the findings are not specific to the German sample or to the specific items used to survey personality traits.

\section{Conclusion}

This article investigates the connection between the glass ceiling in wages and personality traits using data from the SOEP. Overall, the impact of personality traits on wage gaps is modest, but non-negligible. My findings indicate that personality traits explain around $7 \%$ of the overall gender wage gap at the mean in Germany. Furthermore, there is substantial variation in the 
impact of personality traits on gender gaps across the distribution of wages: while personality traits explain $1.9 \%$ of the gender wage gap at the 10th percentile of wages, this share increases to $11.7 \%$ at the 90 th percentile. The impact of personality traits on gender wage gaps is especially driven by differences in endowments between men and women in certain personality traits, especially agreeableness, locus of control and risk taking. Gender differences in these traits are likely to affect productivity and/or wage bargaining behavior with women being disadvantaged.

My findings also indicate that selection into occupations and industries or discrimination in the access to these based on personality traits can hardly explain gender wage gaps. This also holds true for discrimination of women for certain personality traits which could have differential returns compared to males if they conflict with gendered expectations. The findings provide some evidence for both channels, but the effects are dwarfed by the contribution differences in endowments with personality traits.

From a policy perspective, it could be in the interest of the educational system to focus on bolstering personality traits in addition to classical curricula, as suggested by, for example, Heckman (2000). This could especially beneficial for females, as their labor market outcomes are more reactive to changes in non-cognitive skills compared to males (Heckman et al., 2006). Thus, programs that aim at improving non-cognitive skills could also narrow the gender wage gap.

However, the literature (e.g. Fortin, 2005) also shows large country differences in terms of preferences and attitudes. These differences and the resulting societal context could, through e.g. gender stereotypes also affect personality traits, probably to a much larger degree then individual schooling reforms. It would be interesting to also explore country differences with regards to personality traits and gender.

Relatedly, it could be the case that several differences in personality traits between men and women are the outcomes from intra-couple bargaining and reflect differences in bargaining power between partners. This could for example leading to female being more agreeable or scoring higher on the external locus of control-scale, which also potentially cancels out the 
effects of educational programs, as discussed in the previous paragraph. Thus, it is a potential avenue for future research to investigate the interplay between bargaining power and personality traits.

While these findings are important, it should also be noted that the reduction of unexplained gender wage gaps that arises from controlling for personality traits is small and statistically insignificant in most cases. This indicates that, while personality traits in itself seem to be important for wage gaps, their effects are partly captured by other control variables. Thus, the role of personality traits as omitted variables in classical gender wage gap estimations seems to relatively small when one is solely interested in estimating gender wage gaps.

This study has several limitations that could be addressed in future research. First, possibly, the personality traits analyzed in this study do not capture all relevant differences in personality traits between men and women. For example, preferences regarding labor market attitudes could be relevant for wages and are not necessarily captured by the scales used in the analysis. Second, because the wage measures are solely based on self-reported information, there could be systematic differences due to measurement error, e.g. if males and individuals with low scores on the agreeableness-scale tend to overestimate their pay and if being male correlates with agreeableness.

Even after controlling for personality traits and a large set of observable characteristics, the results still show significant mean wage gaps and glass ceilings for women. What drives these remaining gaps remains open for discussion. Discrimination along the job ladder (Lazear and Rosen, 1990) could be an explanation, but should largely be ruled out by controlling for occupation and industry. In the same manner, discrimination in the sense of the pollution theory (Goldin, 2014) should partly be ruled out by control variables like industry and occupation. Taste-based discrimination (Becker, 1971) and sociological theories of gender stereotypes (Ridgeway, 2001) remain plausible explanations for gender wage differentials. 


\section{Acknowledgements}

The author would like to thank Silke Anger, Andreas Eberl, Sabrina Genz, Erik Plug, Malte Reichelt, Regina T. Riphahn, Salwan Saif, the participants of the 23th BGPE Workshop in Würzburg, the participants of the 7IKSWD conference in Berlin, the participants of the 29th EALE conference in St. Gallen, the participations of the 2nd Conference of the Academy for Sociology in Constance and the participants of the IZA World of Labor Conference 2018 in Berlin for their helpful comments. . 


\section{References}

Anger, S., G. Camehl, and F. Peter (2017). Involuntary job loss and changes in personality traits. Journal of Economic Psychology 60, 71-91.

Azmat, G., C. Calsamiglia, and N. Iriberri (2016). Gender Differences in Response to Big Stakes. Journal of the European Economic Association 14(6), 1372-1400.

Becker, G. S. (1971). The Economics of Discrimination (2. ed., 6 ed.). Economics research studies of the Economics Research Center of the University of Chicago. Chicago: Univ. of Chicago Press.

Blau, F. D. and L. M. Kahn (2017). The gender wage gap: Extent, trends, and explanations. Journal of Economic Literature 55(3), 789-865.

Blinder, A. S. (1973). Wage discrimination: reduced form and structural estimates. Journal of Human Resources 8(4), 436-455.

Booth, A. and E. Yamamura (2018). Performance in Mixed-Sex and Single-Sex Competitions: What We Can Learn from Speedboat Races in Japan. The Review of Economics and Statistics 100(4), 581-593.

Bowles, S., H. Gintis, and M. Osborne (2001). Incentive-enhancing preferences: Personality, behavior, and earnings. The American Economic Review 91(2), 155-158.

Braakmann, N. (2009). The Role of Psychological Traits for the Gender Gap in Full-Time Employment and Wages: Evidence from Germany. SOEP Discussion Paper 162. (162).

Brauns, H., S. Scherer, and S. Steinmann (2003). The CASMIN Educational Classification in International Comparative Research. In J. H. P. Hoffmeyer-Zlotnik and C. Wolf (Eds.), Advances in Cross-National Comparison, Volume 16, pp. 221-244. Boston, MA: Springer US. 
Card, D., A. R. Cardoso, and P. Kline (2016). Bargaining, Sorting, and the Gender Wage Gap: Quantifying the Impact of Firms on the Relative Pay of Women. The Quarterly Journal of Economics 131(2), 633-686.

Caroli, E. and C. Garcia-Penalosa (2002). Risk aversion and rising wage inequality. Economics Letters 77(1), 21-26.

Charness, G. and M. Rabin (2002). Understanding Social Preferences with Simple Tests. The Quarterly Journal of Economics 117(3), 817-869.

Christofides, L. N., A. Polycarpou, and K. Vrachimis (2013). Gender wage gaps, 'sticky floors' and 'glass ceilings' in Europe. Labour Economics 21, 86-102.

Cobb-Clark, D. A. and S. Schurer (2012). The stability of big-five personality traits. Economics Letters 115(1), 11-15.

Cobb-Clark, D. A. and S. Schurer (2013). Two Economists' Musings on the Stability of Locus of Control. The Economic Journal 123(570), 358-400.

Collischon, M. (2019). Is There a Glass Ceiling over Germany? German Economic Review 20(4), e329-e359.

Collischon, M. (2020). The Returns to Personality Traits Across the Wage Distribution. LABOUR 34(1), 48-79.

Costa, P. T. and R. R. McCrae (1994). Set like plaster? Evidence for the stability of adult personality. In T. F. Heatherton and J. L. Weinberger (Eds.), Can personality change?, pp. 21-40. Washington: American Psychological Association.

Cotter, D. A., J. M. Hermsen, S. Ovadia, and R. Vanneman (2001). The Glass Ceiling Effect. Social Forces 80(2), 655-681.

Croson, R. and U. Gneezy (2009). Gender Differences in Preferences. Journal of Economic Literature 47(2), 448-474. 
Cubel, M., A. Nuevo-Chiquero, S. Sanchez-Pages, and M. Vidal-Fernandez (2016). Do Personality Traits Affect Productivity? Evidence from the Laboratory. The Economic Journal 126(592), 654-681.

Dehne, M. and J. Schupp (2007). Persönlichkeitsmerkmale im Sozio-oekonomischen Panel (SOEP) - Konzept, Umsetzung und empirische Eigenschaften. DIW Research Note 26.

Dittrich, M., A. Knabe, and K. Leipold (2014). Gender Differences in Experimental Wage Negotiations. Economic Inquiry 52(2), 862-873.

Elder, T. E., J. H. Goddeeris, and S. J. Haider (2010). Unexplained gaps and Oaxaca-Blinder decompositions. Labour Economics 17(1), 284-290.

Elkins, R. K., S. C. Kassenboehmer, and S. Schurer (2017). The stability of personality traits in adolescence and young adulthood. Journal of Economic Psychology.

Fehr, E. and S. Gächter (2000). Cooperation and Punishment in Public Goods Experiments. The American Economic Review 90(4), 980-994.

Firpo, S., N. M. Fortin, and T. Lemieux (2009). Unconditional Quantile Regressions. Econometrica 77(3), 953-973.

Fortin, N., T. Lemieux, and S. Firpo (2011). Decomposition Methods in Economics. In O. Ashenfelter and D. Card (Eds.), Handbook of Labor Economics, Volume 4A, pp. 1-102. Amsterdam: North Holland.

Fortin, N. M. (2005). Gender Role Attitudes and the Labour-market Outcomes of Women across OECD Countries. Oxford Review of Economic Policy 21(3), 416-438.

Fortin, N. M. (2008). The Gender Wage Gap among Young Adults in the United States: The Importance of Money versus People. The Journal of Human Resources 43(4), 884-918. 
Goldin, C. (2014). A Pollution Theory of Discrimination: Male and Female Differences in Occupations and Earnings. In Leah Platt Boustan, Carola Frydman, and Robert A. Margo (Eds.), Human Capital in History: The American Record, pp. 313-348. University of Chicago Press.

Heckman, J. J. (1979). Sample Selection Bias as a Specification Error. Econometrica 47(1), $153-161$

Heckman, J. J. (2000). Policies to foster human capital. Research in Economics 54(1), 3-56.

Heckman, J. J., J. Stixrud, and S. Urzua (2006). The Effects of Cognitive and Noncognitive Abilities on Labor Market Outcomes and Social Behavior. Journal of Labor Economics 24(3), 411-482.

Heineck, G. (2011). Does it pay to be nice? Personality and Earnings in the United Kingdom. Industrial and Labor Relations Review 64(5), 1020-1038.

Heineck, G. and S. Anger (2010). The returns to cognitive abilities and personality traits in Germany. Labour Economics 17(3), 535-546.

Heinz, M., H.-T. Normann, and H. A. Rau (2016). How competitiveness may cause a gender wage gap: Experimental evidence. European Economic Review 90, 336-349.

Hinz, T. and H. Gartner (2005). Geschlechtsspezifische Lohnunterschiede in Branchen, Berufen und Betrieben. Zeitschrift für Soziologie, 22-39.

Jann, B. (2008). The Blinder-Oaxaca Decomposition for Linear Regression Models. The Stata Journal: Promoting communications on statistics and Stata 8(4), 453-479.

John, K. and S. L. Thomsen (2014). Heterogeneous returns to personality: The role of occupational choice. Empirical Economics 47(2), 553-592.

Jones, F. L. and J. Kelley (1984). Decomposing Differences between Groups. Sociological Methods \& Research 12(3), 323-343. 
Judge, T. A., C. A. Higgins, C. J. Thoresen, and M. R. Barrick (1999). The Big Five Personality Traits, general mental ability, and Career Success across the Life Span. Personnel Psychology 52(3), 621-652.

Kee, H. J. (2006). Glass Ceiling or Sticky Floor? Exploring the Australian Gender Pay Gap. Economic Record 82(259), 408-427.

Killewald, A. and J. Bearak (2014). Is the Motherhood Penalty Larger for Low-Wage Women? A Comment on Quantile Regression. American Sociological Review 79(2), 350-357.

Kitagawa, E. M. (1955). Components of a Difference Between Two Rates*. Journal of the American Statistical Association 50(272), 1168-1194.

Koenker, R. and G. Bassett (1978). Regression Quantiles. Econometrica 46(1), 33-50.

Lazear, E. P. and S. Rosen (1990). Male-Female Wage Differentials in Job Ladders. Journal of Labor Economics 8(1), S106-S123.

Losoncz, I. (2009). Personality traits in HILDA. Australian Social Policy 8, 169-198.

Maume, D. J. (1999). Glass Ceilings and Glass Escalators. Work and Occupations 26(4), 483-509.

McCrae, R. R. and P. T. Costa (2008). The five-factor theory of personality. In O. P. John, R. W. Robins, and L. A. Pervin (Eds.), Handbook of personality. New York: Guilford Press.

McGee, A., P. McGee, and J. Pan (2015). Performance pay, competitiveness, and the gender wage gap: Evidence from the United States. Economics Letters 128, 35-38.

Mueller, G. and E. Plug (2006). Estimating the Effect of Personality on Male and Female Earnings. Industrial and Labor Relations Review 60(1), 3-22.

Nandi, A. and C. Nicoletti (2014). Explaining personality pay gaps in the UK. Applied Economics 46(26), 3131-3150. 
Neumark, D. (1988). Employers' discriminatory behavior and the estimation of wage discrimination. The Journal of Human Resources 23(3), 279-295.

Niederle, M. and L. Vesterlund (2007). Do Women Shy Away From Competition? Do Men Compete Too Much? The Quarterly Journal of Economics 122(3), 1067-1101.

Nyhus, E. K. and E. Pons (2012). Personality and the gender wage gap. Applied Economics 44(1), 105-118.

Oaxaca, R. (1973). Male-female wage differentials in urban labor markets. International Economic Review 14(3), 693-709.

Oaxaca, R. L. and M. R. Ransom (1994). On discrimination and the decomposition of wage differentials. Journal of Econometrics 61(1), 5-21.

Olivetti, C. and B. Petrongolo (2008). Unequal Pay or Unequal Employment? A Cross-Country Analysis of Gender Gaps. Journal of Labor Economics 26(4), 621-654.

Rantanen, J., R.-L. Metsäpelto, T. Feldt, L. Pulkkinen, and K. Kokko (2007). Long-term stability in the Big Five personality traits in adulthood. Scandinavian journal of psychology 48(6), $511-518$.

Ridgeway, C. L. (2001). Gender, status, and leadership. Journal of Social Issues 57(4), 637655.

Risse, L., L. Farrell, and T. R. L. Fry (2018). Personality and pay: Do gender gaps in confidence explain gender gaps in wages? Oxford Economic Papers 37, 535.

Rotter, J. B. (1966). Generalized expectancies for internal versus external control of reinforcement. Psychological Monographs: General and Applied 80(1), 1-28.

Rudman, L. A. and P. Glick (2001). Prescriptive Gender Stereotypes and Backlash Toward Agentic Women. Journal of Social Issues 57(4), 743-762. 
Semykina, A. and S. J. Linz (2007). Gender differences in personality and earnings: Evidence from Russia. Journal of Economic Psychology 28(3), 387-410.

Socio-Economic Panel (SOEP) (2016). Data from 1984-2015, version 32.

Solon, G., S. J. Haider, and J. M. Wooldridge (2015). What Are We Weighting For? Journal of Human Resources 50(2), 301-316.

Stuhlmacher, A. F. and A. E. Walters (1999). Gender Differences in Negotiation Outcome: A meta-analysis. Personnel Psychology 52(3), 653-677.

The Guardian (2011). Women still face a glass ceiling.

University of Essex. Institute for Social and Economic Research NatCen Social Research Kantar Public (2016). Understanding Society: Waves 1-6, 2009-2015.

Wagner, G. and J. R. Frick (2007). The German Socio-Economic Panel Study (SOEP) - Scope, Evolution and Enhancements. Schmollers Jahrbuch 127(1), 139-169.

Williams, J. E., R. C. Satterwhite, and D. L. Best (1999). Pancultural Gender Stereotypes Revisited: The Five Factor Model. Sex Roles 40(7/8), 513-525.

Wooden, M. and N. Watson (2007). The HILDA Survey and its Contribution to Economic and Social Research (So Far). Economic Record 83(261), 208-231. 
Table 1: Hypotheses concerning the impact of personality traits on wage gaps.

\begin{tabular}{lccccc}
\hline Channel & \multicolumn{2}{c}{$\begin{array}{c}\text { Difference in... } \\
\text { Endowments }\end{array}$} & $\begin{array}{c}\text { Through job } \\
\text { Returns }\end{array}$ & $\begin{array}{c}\text { Potential variation across } \\
\text { characteristics }\end{array}$ & Traits \\
\hline thoductivity & $\checkmark$ & - & - & $\checkmark$ & Neuroticism, conscientiousness, openness, reciprocity \\
Bargaining & $\checkmark$ & - & - & External locus of control, agreeableness, risk taking \\
Self-selection into jobs & $\checkmark$ & - & $\checkmark$ & Multiple \\
Discrimination: deviant behavior & - & $\checkmark$ & - & Agreeableness, risk taking \\
Discrimination: job entry & $\checkmark$ & - & $\checkmark$ & Multiple \\
\hline
\end{tabular}

Notes: This table summarizes through which channels personality traits could affect gender wage gaps. Differences in endowments refers to mean differences between men and women in certain personality traits that could explain gender gaps. Difference in returns means that I expect the coefficients for certain personality traits to differ between men and women. Through job characteristics means that if this channel is relevant, controlling for occupation and industry should reduce the impact of personality traits on gender wage gaps. 
Table 2: Samples descriptives by gender.

\begin{tabular}{lrrrr}
\hline & \multicolumn{2}{c}{ Male (N=80,596) } & \multicolumn{2}{c}{ Female (N=72,181) } \\
& \multicolumn{1}{c}{ Mean } & \multicolumn{1}{c}{ SD } & \multicolumn{1}{c}{ Mean } & \multicolumn{1}{c}{ SD } \\
\hline Hourly wages (EUR2010) & 19.444 & 14.494 & 14.428 & 9.695 \\
Age & 42.708 & 11.200 & 42.255 & 11.119 \\
East Germany (0/1) & 0.218 & 0.413 & 0.241 & 0.427 \\
Married (0/1) & 0.655 & 0.475 & 0.609 & 0.488 \\
Child under 16 (0/1) & 0.403 & 0.491 & 0.373 & 0.484 \\
Direct migration background (0/1) & 0.113 & 0.316 & 0.105 & 0.306 \\
Indirect migration background (0/1) & 0.037 & 0.190 & 0.035 & 0.185 \\
Experience full time (years) & 19.777 & 11.569 & 12.557 & 10.335 \\
Experience part time (years) & 0.561 & 1.840 & 5.323 & 6.945 \\
Experience unemployment (years) & 0.446 & 1.287 & 0.576 & 1.528 \\
Tenure (years) & 12.288 & 10.621 & 10.097 & 9.442 \\
Full time employment (0/1) & 0.924 & 0.265 & 0.526 & 0.499 \\
Public employer (0/1) & 0.227 & 0.419 & 0.335 & 0.472 \\
CASMIN Inadequately completed (1a) & 0.014 & 0.117 & 0.012 & 0.110 \\
CASMIN General elementary (1b) & 0.052 & 0.223 & 0.061 & 0.240 \\
CASMIN Basic vocational (1c) & 0.273 & 0.445 & 0.182 & 0.386 \\
CASMIN Intermediate general (2b) & 0.029 & 0.169 & 0.041 & 0.199 \\
CASMIN Intermediate vocational (2a) & 0.274 & 0.446 & 0.343 & 0.475 \\
CASMIN General maturity (2c_gen) & 0.027 & 0.162 & 0.027 & 0.163 \\
CASMIN Vocational maturity (2c_voc) & 0.072 & 0.259 & 0.090 & 0.286 \\
CASMIN Lower tertiarty (3a) & 0.081 & 0.273 & 0.066 & 0.248 \\
CASMIN Higher tertiary (3b) & 0.178 & 0.382 & 0.177 & 0.381 \\
Firm size <10 & 0.117 & 0.321 & 0.173 & 0.378 \\
Firm size 10-99 & 0.281 & 0.449 & 0.310 & 0.462 \\
Firm size 100-199 & 0.074 & 0.262 & 0.077 & 0.267 \\
Firm size 200-1999 & 0.245 & 0.430 & 0.221 & 0.415 \\
Firm size 2000+ & 0.284 & 0.451 & 0.218 & 0.413 \\
\hline & & & & \\
& & 0.45 &
\end{tabular}

Notes: Sample descriptives by gender; omitted: ISCO 2-digit groups and NACE groups, available in Appendix Tables A2 and A3. Source: SOEP v32 1991-2015, own calculations. 
Table 3: Descriptive statistics of personality traits by gender and managerial status.

\begin{tabular}{lrccrrrr}
\hline & \multicolumn{3}{c}{ By gender } & \multicolumn{3}{c}{ By managerial statis } \\
\cline { 2 - 6 } & $\begin{array}{c}\text { Male } \\
\text { (1) }\end{array}$ & $\begin{array}{c}\text { Female } \\
\text { (2) }\end{array}$ & $\begin{array}{c}\text { Difference (1)-(2) } \\
(3)\end{array}$ & $\begin{array}{c}\text { Non-managers } \\
(4)\end{array}$ & $\begin{array}{c}\text { Managers } \\
(5)\end{array}$ & $\begin{array}{c}\text { Difference (4)-(5) } \\
(6)\end{array}$ \\
\hline Extraversion & -0.109 & 0.141 & $-0.249^{* * *}$ & 0.011 & -0.005 & $0.015^{+}$ \\
Agreeableness & -0.170 & 0.147 & $-0.318^{* * *}$ & -0.009 & -0.133 & $0.124^{* * *}$ \\
Conscientiousness & -0.033 & 0.117 & $-0.150^{* * *}$ & 0.048 & -0.063 & $0.110^{* * *}$ \\
Neuroticism & -0.268 & 0.112 & $-0.380^{* * *}$ & -0.072 & -0.257 & $0.185^{* * *}$ \\
Openness & -0.074 & 0.089 & $-0.162^{* * *}$ & -0.006 & 0.102 & $-0.108^{* * *}$ \\
External locus of control & -0.135 & -0.019 & $-0.116^{* * *}$ & -0.062 & -0.269 & $0.207^{* * *}$ \\
Positive reciprocity & 0.050 & 0.027 & $0.023^{* * *}$ & 0.039 & 0.041 & -0.002 \\
Negative reciprocity & 0.146 & -0.131 & $0.276^{* * *}$ & 0.015 & 0.011 & 0.005 \\
Risk taking & 0.218 & -0.139 & $0.357^{* * *}$ & 0.033 & 0.220 & $-0.187^{* * *}$ \\
Hourly wages (EUR2010) & 19.444 & 14.428 & $5.017^{* * *}$ & 16.440 & 23.628 & $-7.189^{* * *}$ \\
Female & & & & 0.492 & 0.269 & $0.223^{* * *}$ \\
\hline
\end{tabular}

Notes: Mean values of personality traits by gender and managerial status and comparisons of these via t-tests. Significance levels: * $p<0.05,{ }^{* *} p<0.01,{ }^{* * *} p<0.001$. Sources: SOEP v32 1991-2015. 
Table 4: Results of the FFL-decompositions.

\begin{tabular}{|c|c|c|c|c|c|c|c|c|c|c|c|c|}
\hline & \multicolumn{4}{|c|}{ w/o Occupation and Industry (N=152,777) } & \multicolumn{4}{|c|}{ w/ Occupation and Industry (N=152,777) } & \multicolumn{4}{|c|}{ Accounting for selection $(\mathrm{N}=208,763)$} \\
\hline & $\begin{array}{l}\text { Mean } \\
\text { (1) }\end{array}$ & $\begin{array}{l}10^{t h} \\
\text { Percentile } \\
\text { (2) }\end{array}$ & $\begin{array}{c}50^{t h} \\
\text { Percentile } \\
\text { (3) }\end{array}$ & $\begin{array}{c}90^{t h} \\
\text { Percentile } \\
\text { (4) }\end{array}$ & $\begin{array}{l}\text { Mean } \\
\text { (5) }\end{array}$ & $\begin{array}{c}10^{t h} \\
\text { Percentile } \\
\text { (6) }\end{array}$ & $\begin{array}{c}50^{t h} \\
\text { Percentile } \\
\text { (7) }\end{array}$ & $\begin{array}{c}90^{t h} \\
\text { Percentile } \\
\text { (8) }\end{array}$ & $\begin{array}{c}\text { Mean } \\
\text { Percentile } \\
\text { (9) }\end{array}$ & $\begin{array}{c}10^{t h} \\
\text { Percentile } \\
\text { (10) }\end{array}$ & $\begin{array}{c}50^{t h} \\
\text { Percentile } \\
\text { (11) }\end{array}$ & $\begin{array}{c}90^{t h} \\
\text { Percentile } \\
\text { (12) }\end{array}$ \\
\hline Raw gap & $\begin{array}{l}0.273^{* * *} \\
(0.008)\end{array}$ & $\begin{array}{l}0.287^{* * *} \\
(0.014)\end{array}$ & $\begin{array}{l}0.256^{* * *} \\
(0.008)\end{array}$ & $\begin{array}{l}0.300^{* * *} \\
(0.013)\end{array}$ & $\begin{array}{l}0.273^{* * *} \\
(0.008)\end{array}$ & $\begin{array}{l}0.287^{* * *} \\
(0.014)\end{array}$ & $\begin{array}{l}0.256^{* * *} \\
(0.008)\end{array}$ & $\begin{array}{l}0.300^{* * *} \\
(0.013)\end{array}$ & $\begin{array}{l}0.276^{* * *} \\
(0.008)\end{array}$ & $\begin{array}{l}0.248^{* * *} \\
(0.014)\end{array}$ & $\begin{array}{l}0.267^{* * *} \\
(0.008)\end{array}$ & $\begin{array}{l}0.311^{* * *} \\
(0.013)\end{array}$ \\
\hline \multicolumn{13}{|c|}{ (A) without personality traits } \\
\hline Explained & $\begin{array}{l}0.154^{* * *} \\
(0.007)\end{array}$ & $\begin{array}{l}0.288^{* * *} \\
(0.012)\end{array}$ & $\begin{array}{l}0.109^{* * *} \\
(0.007)\end{array}$ & $\begin{array}{l}0.108^{* * *} \\
(0.010)\end{array}$ & $\begin{array}{l}0.152^{* * *} \\
(0.008)\end{array}$ & $\begin{array}{l}0.275^{* * *} \\
(0.013)\end{array}$ & $\begin{array}{l}0.118^{* * *} \\
(0.007)\end{array}$ & $\begin{array}{l}0.101^{* * *} \\
(0.011)\end{array}$ & $\begin{array}{c}0.007 \\
(0.005)\end{array}$ & $\begin{array}{c}0.014^{*} \\
(0.007)\end{array}$ & $\begin{array}{c}0.004 \\
(0.004)\end{array}$ & $\begin{array}{c}0.002 \\
(0.006)\end{array}$ \\
\hline Unexplained & $\begin{array}{l}0.120^{* * *} \\
(0.006)\end{array}$ & $\begin{array}{c}-0.002 \\
(0.014)\end{array}$ & $\begin{array}{l}0.147^{* * *} \\
(0.007)\end{array}$ & $\begin{array}{l}0.193^{* * *} \\
(0.013)\end{array}$ & $\begin{array}{l}0.121^{* * *} \\
(0.006)\end{array}$ & $\begin{array}{c}0.012 \\
(0.014)\end{array}$ & $\begin{array}{l}0.138^{* * *} \\
(0.007)\end{array}$ & $\begin{array}{l}0.199^{* * *} \\
(0.014)\end{array}$ & $\begin{array}{l}0.269^{* * *} \\
(0.006)\end{array}$ & $\begin{array}{l}0.234^{* * *} \\
(0.013)\end{array}$ & $\begin{array}{l}0.263^{* * *} \\
(0.007)\end{array}$ & $\begin{array}{l}0.310^{* * *} \\
(0.011)\end{array}$ \\
\hline \multicolumn{13}{|c|}{ (B) with personality traits } \\
\hline Explained & $\begin{array}{l}0.168^{* * *} \\
(0.007)\end{array}$ & $\begin{array}{l}0.290^{* * *} \\
(0.013)\end{array}$ & $\begin{array}{l}0.124^{* * *} \\
(0.007)\end{array}$ & $\begin{array}{l}0.134^{* * *} \\
(0.010)\end{array}$ & $\begin{array}{l}0.164^{* * *} \\
(0.008)\end{array}$ & $\begin{array}{l}0.277^{* * *} \\
(0.014)\end{array}$ & $\begin{array}{l}0.129^{* * *} \\
(0.008)\end{array}$ & $\begin{array}{l}0.122^{* * *} \\
(0.012)\end{array}$ & $\begin{array}{l}0.033^{* * *} \\
(0.006)\end{array}$ & $\begin{array}{l}0.029^{* * *} \\
(0.008)\end{array}$ & $\begin{array}{l}0.025^{* * *} \\
(0.005)\end{array}$ & $\begin{array}{l}0.044^{* * *} \\
(0.008)\end{array}$ \\
\hline Unexplained & $\begin{array}{l}0.106^{* * *} \\
(0.007)\end{array}$ & $\begin{array}{c}-0.003 \\
(0.014)\end{array}$ & $\begin{array}{l}0.132^{* * *} \\
(0.007)\end{array}$ & $\begin{array}{l}0.167^{* * *} \\
(0.013)\end{array}$ & $\begin{array}{l}0.109^{* * *} \\
(0.007)\end{array}$ & $\begin{array}{c}0.009 \\
(0.015)\end{array}$ & $\begin{array}{l}0.126^{* * *} \\
(0.007)\end{array}$ & $\begin{array}{l}0.178^{* * *} \\
(0.014)\end{array}$ & $\begin{array}{l}0.243^{* * *} \\
(0.007)\end{array}$ & $\begin{array}{l}0.220^{* * *} \\
(0.014)\end{array}$ & $\begin{array}{l}0.242^{* * *} \\
(0.007)\end{array}$ & $\begin{array}{l}0.267^{* * *} \\
(0.012)\end{array}$ \\
\hline \multicolumn{13}{|l|}{ Detailed decomposition } \\
\hline \multicolumn{13}{|l|}{ Explained } \\
\hline Extraversion & 0.001 & 0.002 & $0.001^{+}$ & 0.001 & 0.001 & 0.001 & 0.001 & 0.001 & $0.002^{*}$ & 0.002 & $0.001^{+}$ & 0.002 \\
\hline Agreeableness & $0.006^{* * *}$ & 0.002 & $0.006^{* * *}$ & $0.010^{* * *}$ & $0.005^{* * *}$ & 0.001 & $0.005^{* * *}$ & $0.009^{* * *}$ & $0.011^{* * *}$ & $0.009^{* * *}$ & $0.010^{* * *}$ & $0.014^{* * *}$ \\
\hline Conscientiousness & $0.001^{*}$ & 0.000 & $0.002^{* * *}$ & 0.000 & 0.000 & 0.000 & 0.000 & -0.001 & 0.000 & $-0.003^{* *}$ & $0.002^{* *}$ & 0.000 \\
\hline Neuroticism & $0.003^{* *}$ & 0.002 & $0.003^{*}$ & $0.006^{* *}$ & $0.003^{* *}$ & 0.001 & $0.002^{*}$ & $0.005^{* *}$ & $0.008^{* * *}$ & $0.009^{* * *}$ & $0.006^{* * *}$ & $0.007^{* * *}$ \\
\hline Openness & $-0.002^{* * *}$ & 0.000 & $-0.002^{* * *}$ & $-0.002^{+}$ & 0.000 & 0.001 & 0.000 & 0.000 & -0.001 & $0.002^{+}$ & $-0.001^{+}$ & -0.001 \\
\hline External locus of & $0.005^{* * *}$ & $0.005^{* * *}$ & $0.003^{* * *}$ & $0.007^{* * *}$ & $0.004^{* * *}$ & $0.005^{* * *}$ & $0.002^{* * *}$ & $0.005^{* * *}$ & $0.006^{* * *}$ & $0.006^{* * *}$ & $0.005^{* * *}$ & $0.008^{* * *}$ \\
\hline Positive reciprocity & 0.000 & 0.000 & 0.000 & 0.000 & 0.000 & 0.000 & 0.000 & 0.000 & 0.000 & 0.001 & 0.000 & 0.000 \\
\hline Negative reciprocity & $-0.002^{*}$ & -0.002 & $-0.002^{*}$ & -0.001 & 0.000 & -0.001 & 0.000 & 0.000 & -0.001 & -0.001 & $-0.002^{*}$ & 0.001 \\
\hline Risk taking & $0.003^{* * *}$ & $-0.006^{* *}$ & $0.004^{* * *}$ & $0.008^{* * *}$ & $0.003^{* * *}$ & $-0.004^{*}$ & $0.004^{* * *}$ & $0.007^{* * *}$ & 0.000 & $-0.010^{* * *}$ & -0.001 & $0.010^{* * *}$ \\
\hline \multicolumn{13}{|l|}{ Unexplained } \\
\hline Extraversion & 0.000 & 0.001 & 0.000 & $-0.001^{* *}$ & 0.000 & 0.001 & 0.000 & $-0.001^{*}$ & 0.000 & 0.001 & 0.000 & $-0.001^{* *}$ \\
\hline Agreeableness & 0.000 & $-0.001^{+}$ & $0.000^{+}$ & $0.001^{* *}$ & 0.000 & 0.000 & 0.000 & $0.001^{* *}$ & $0.000^{* *}$ & $-0.002^{* * *}$ & $0.000^{*}$ & 0.001 \\
\hline Conscientiousness & 0.000 & $0.001^{+}$ & 0.000 & 0.000 & 0.000 & 0.001 & 0.000 & 0.000 & 0.000 & $0.002^{*}$ & 0.000 & 0.000 \\
\hline Neuroticism & $0.001^{* *}$ & $0.002^{*}$ & 0.001 & 0.002 & $0.001^{* *}$ & $0.002^{*}$ & $0.001^{+}$ & $0.001^{+}$ & $0.001^{* *}$ & $0.001^{+}$ & $0.001^{*}$ & $0.002^{* *}$ \\
\hline Openness & 0.000 & 0.000 & 0.000 & 0.000 & 0.000 & 0.000 & $0.000^{+}$ & 0.000 & 0.000 & 0.000 & 0.000 & 0.000 \\
\hline External locus of control & $0.001^{*}$ & $-0.002^{+}$ & $0.001^{+}$ & $0.003^{* * *}$ & $0.001^{*}$ & $-0.002^{+}$ & 0.001 & $0.002^{* *}$ & 0.000 & $-0.001^{+}$ & 0.000 & $0.002^{* *}$ \\
\hline Positive reciprocity & 0.000 & $0.001^{+}$ & 0.000 & 0.001 & $0.000^{+}$ & $0.001^{+}$ & 0.000 & 0.001 & 0.000 & 0.000 & 0.000 & 0.000 \\
\hline Negative reciprocity & 0.000 & 0.000 & 0.000 & 0.000 & 0.000 & 0.000 & 0.000 & 0.000 & 0.000 & 0.000 & 0.000 & 0.000 \\
\hline Risk taking & 0.000 & $0.001^{*}$ & 0.000 & 0.000 & 0.000 & 0.001 & 0.000 & 0.000 & 0.000 & $0.001^{+}$ & 0.000 & 0.000 \\
\hline
\end{tabular}

Notes: Cluster-robust standard errors in parentheses. The dependent variable is the natural logarithm of the hourly wage. Every estimation accounts for the full set of control variables. Significance levels: ${ }^{*} p<0.05,{ }^{* *} p<0.01,{ }^{* * *} p<0.001$. Sources: SOEP v32 1991-2015, own calculations. 
Table 5: Robustness checks: unexplained wage gaps derived from decompositions with and without personality traits using different specifications.

\begin{tabular}{|c|c|c|c|c|}
\hline & Mean & $\begin{array}{c}10^{t h} \\
\text { Percentile }\end{array}$ & $\begin{array}{c}50^{t h} \\
\text { Percentile }\end{array}$ & $\begin{array}{c}90^{t h} \\
\text { Percentile }\end{array}$ \\
\hline \multicolumn{5}{|c|}{ (A) Non-linearities ${ }^{1}$} \\
\hline W/o personality traits & $\begin{array}{l}0.120^{* * *} \\
(0.006)\end{array}$ & $\begin{array}{c}-0.002 \\
(0.013)\end{array}$ & $\begin{array}{l}0.147^{* * *} \\
(0.007)\end{array}$ & $\begin{array}{l}0.193^{* * *} \\
(0.012)\end{array}$ \\
\hline $\mathrm{W} /$ personality traits & $\begin{array}{l}0.106^{* * *} \\
(0.007)\end{array}$ & $\begin{array}{c}-0.004 \\
(0.014)\end{array}$ & $\begin{array}{l}0.135^{* * *} \\
(0.007)\end{array}$ & $\begin{array}{l}0.165^{* * *} \\
(0.013)\end{array}$ \\
\hline \multicolumn{5}{|c|}{ (B) Age 30-55 } \\
\hline W/o personality traits & $\begin{array}{l}0.138^{* * *} \\
(0.008)\end{array}$ & $\begin{array}{l}0.121^{* * *} \\
(0.014)\end{array}$ & $\begin{array}{l}0.134^{* * *} \\
(0.008)\end{array}$ & $\begin{array}{l}0.167^{* * *} \\
(0.014)\end{array}$ \\
\hline $\mathrm{W} /$ personality traits & $\begin{array}{l}0.124^{* * *} \\
(0.008)\end{array}$ & $\begin{array}{l}0.114^{* * *} \\
(0.014)\end{array}$ & $\begin{array}{l}0.123^{* * *} \\
(0.008)\end{array}$ & $\begin{array}{l}0.149^{* * *} \\
(0.014)\end{array}$ \\
\hline \multicolumn{5}{|c|}{ (C) Full time employees } \\
\hline W/o personality traits & $\begin{array}{l}0.144^{* * *} \\
(0.007)\end{array}$ & $\begin{array}{l}0.152^{* * *} \\
(0.013)\end{array}$ & $\begin{array}{l}0.130^{* * *} \\
(0.007)\end{array}$ & $\begin{array}{l}0.132^{* * *} \\
(0.012)\end{array}$ \\
\hline $\mathrm{W} /$ personality traits & $\begin{array}{l}0.125^{* * *} \\
(0.007)\end{array}$ & $\begin{array}{l}0.140^{* * *} \\
(0.013)\end{array}$ & $\begin{array}{l}0.113^{* * *} \\
(0.008)\end{array}$ & $\begin{array}{l}0.107^{* * *} \\
(0.013)\end{array}$ \\
\hline \multicolumn{5}{|c|}{ (D) Using survey weights } \\
\hline W/o personality traits & $\begin{array}{l}0.117^{* * *} \\
(0.007)\end{array}$ & $\begin{array}{c}-0.003 \\
(0.014)\end{array}$ & $\begin{array}{l}0.145^{* * *} \\
(0.007)\end{array}$ & $\begin{array}{l}0.188^{* * *} \\
(0.013)\end{array}$ \\
\hline $\mathrm{W} /$ personality traits & $\begin{array}{l}0.104^{* * *} \\
(0.007)\end{array}$ & $\begin{array}{c}-0.004 \\
(0.014)\end{array}$ & $\begin{array}{l}0.131^{* * *} \\
(0.007)\end{array}$ & $\begin{array}{l}0.163^{* * *} \\
(0.013)\end{array}$ \\
\hline \multicolumn{5}{|c|}{ (E) Heckman (1979) correction ${ }^{2}$} \\
\hline W/o personality traits & $\begin{array}{l}0.103^{* * *} \\
(0.017)\end{array}$ & $\begin{array}{l}-0.279^{* * *} \\
(0.024)\end{array}$ & $\begin{array}{l}0.233^{* * *} \\
(0.014)\end{array}$ & $\begin{array}{l}0.248^{* * *} \\
(0.026)\end{array}$ \\
\hline $\mathrm{W} /$ personality traits & $\begin{array}{l}0.087^{* * *} \\
(0.013)\end{array}$ & $\begin{array}{l}-0.283^{* * *} \\
(0.024)\end{array}$ & $\begin{array}{l}0.217^{* * *} \\
(0.013)\end{array}$ & $\begin{array}{l}0.221^{* * *} \\
(0.026)\end{array}$ \\
\hline
\end{tabular}

Notes: Cluster-robust standard errors in parentheses. The dependent variable is the natural logarithm of the hourly wage. Every estimation accounts for the full set of control variables without occupation and industry. Significance levels: + $p<0.1,{ }^{*} p<0.05,{ }^{* *} p<0.01,{ }^{* * *} p<0.001$.

${ }^{1}$ Instead of continous measures for personality traits, this estimation includes dummies for being in the top or bottom $25 \%$ of the distribution of a given trait in the population. ${ }^{2}$ Standard errors in the sample-selection estimations are obtained from cluster bootstrapping.

Source: SOEP v32 1991-2015, own calculations. 


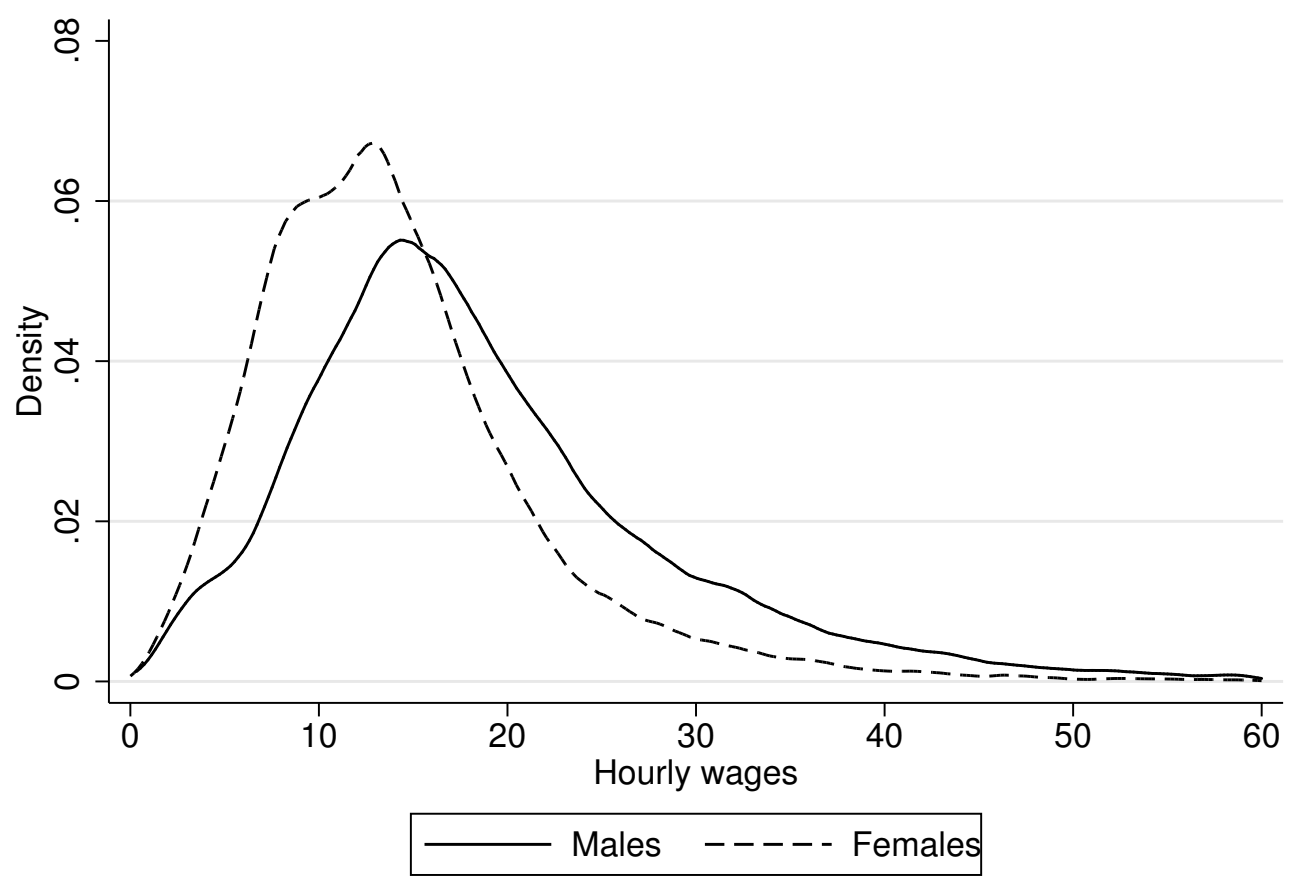

Sources: SOEP v32 1991-2015; own calculations.

Figure 1: Distribution of hourly wages below the 99th percentile in EUR2010 by gender. 
(a) Big Five
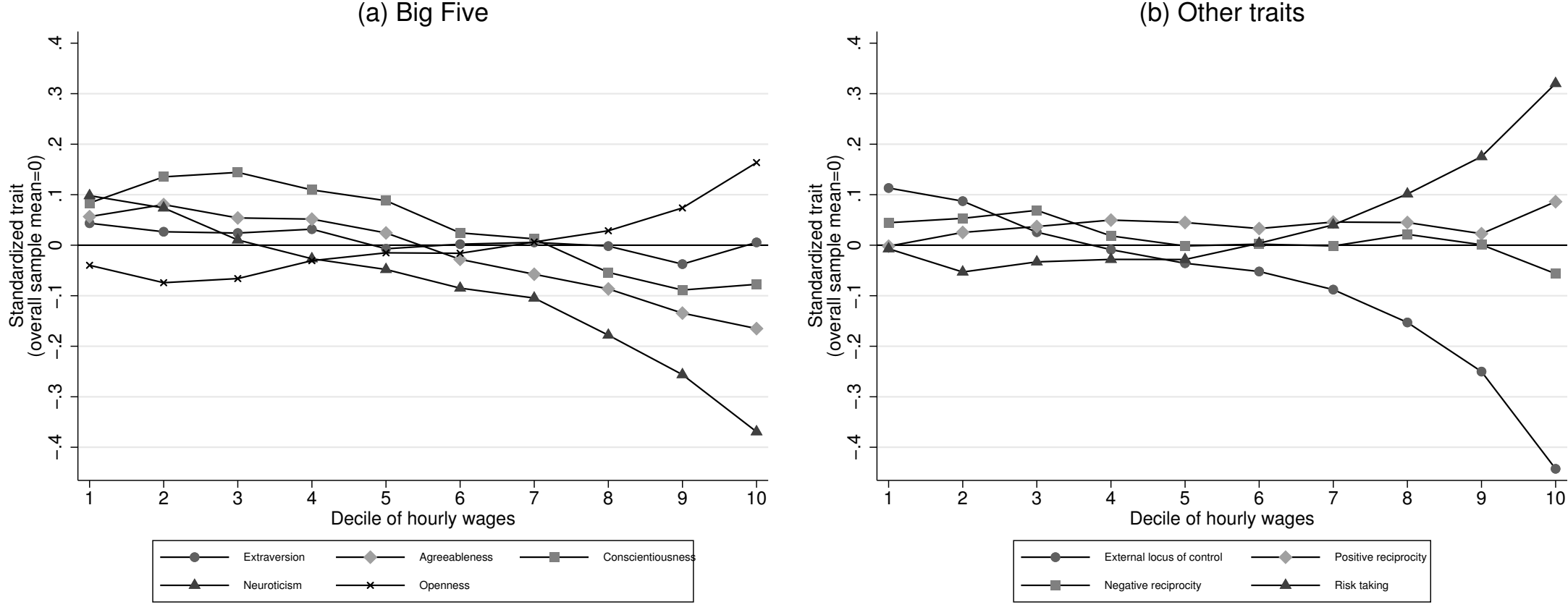

Sources: SOEP v32 1991-2015; own calculations.

Figure 2: Distribution of personality traits across the distribution of wages, measured in deciles. 
(a) w/o occupation + industry

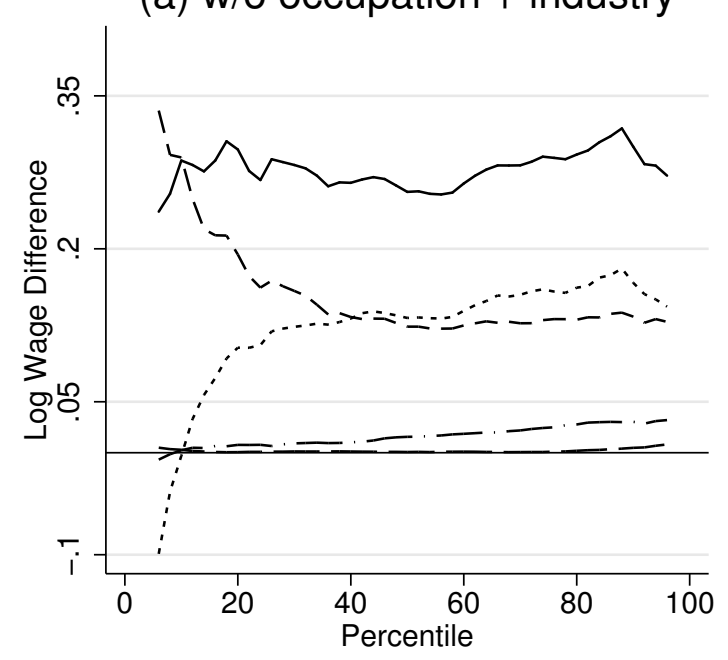

(b) w/ occupation + industry

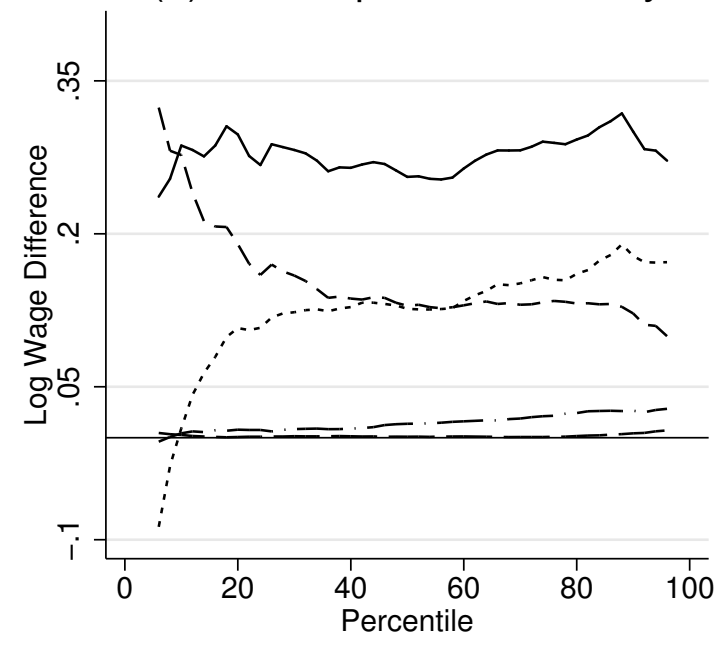

(c) imputed wages

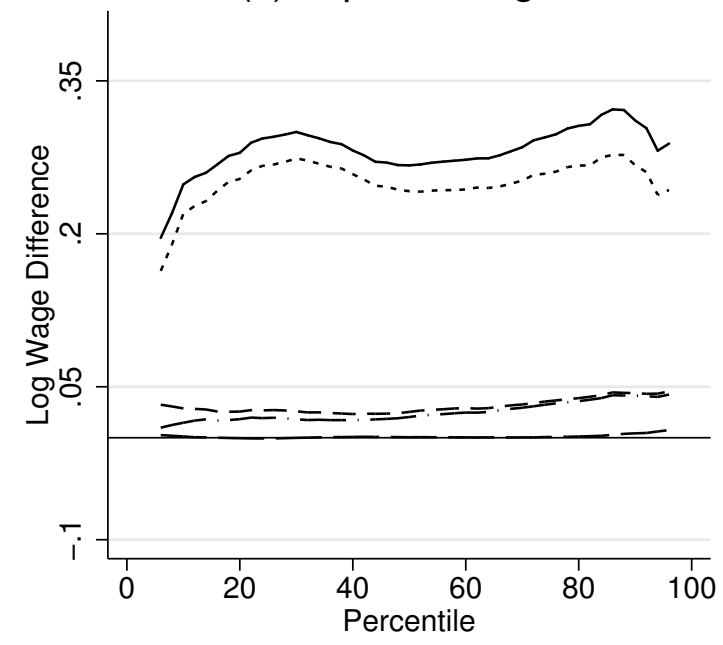

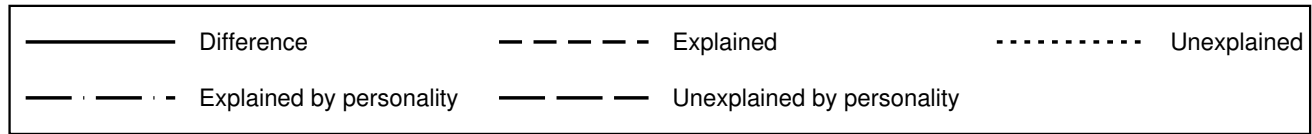

Sources: SOEP v32 1991-2015; own calculations.

Figure 3: Decomposition results for the main analysis. The graphs correspond to the results in Table 4. 


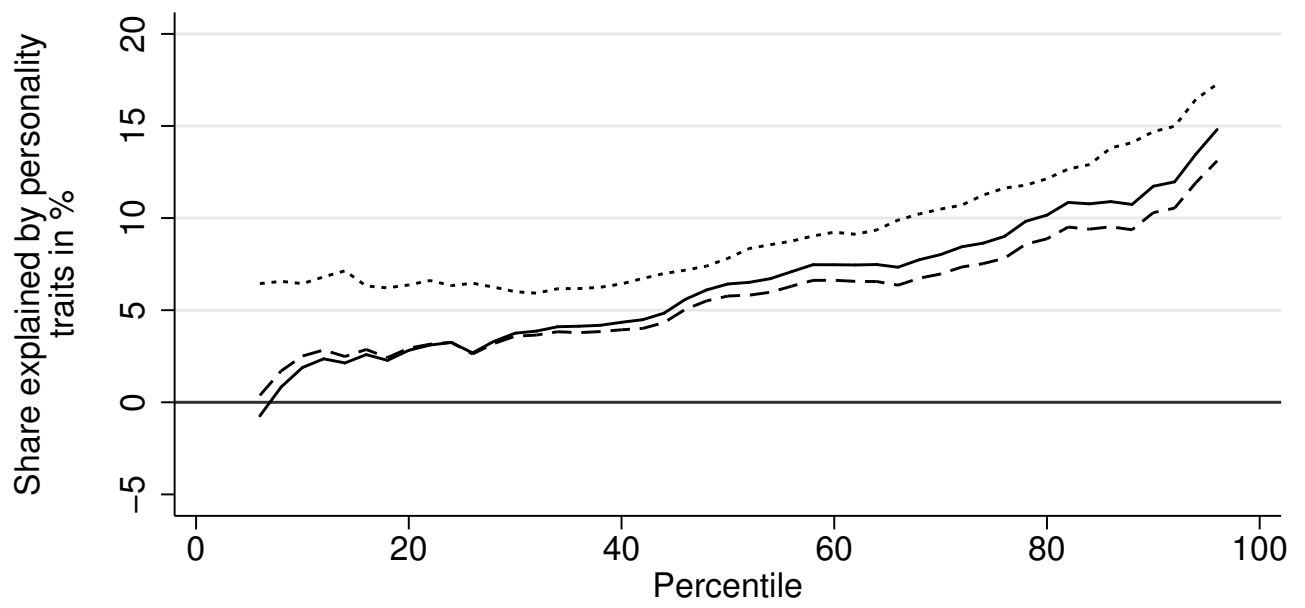

Figure 4: Share of the gender wage gap explained by personality traits across the wage distribution. The graphs correspond to the results in Table 4. 
Appendix A: Additional Tables and Figures 
Table A1: Sample descriptives across the wage distribution.

\begin{tabular}{|c|c|c|c|c|c|c|}
\hline & \multicolumn{2}{|c|}{$\leq 10^{\text {th }}$ percentile } & \multicolumn{2}{|c|}{$\left[45^{t h} ; 55^{\text {th }}\right]$ percentile } & \multicolumn{2}{|c|}{$\geq 90^{\text {th }}$ percentile } \\
\hline & Male $(\mathrm{N}=5571)$ & Female $(\mathrm{N}=9708)$ & Male $(\mathrm{N}=7832)$ & Female $(\mathrm{N}=7456)$ & Male (N=11652) & Female $(\mathrm{N}=3627)$ \\
\hline \multicolumn{7}{|c|}{ (A) Personality traits } \\
\hline Extraversion & -0.089 & 0.120 & -0.118 & 0.116 & -0.067 & 0.239 \\
\hline Agreeableness & -0.125 & 0.161 & -0.164 & 0.171 & -0.213 & -0.012 \\
\hline Conscientiousness & -0.047 & 0.159 & 0.021 & 0.102 & -0.106 & 0.014 \\
\hline Neuroticism & -0.168 & 0.251 & -0.223 & 0.093 & -0.446 & -0.122 \\
\hline Openness & -0.142 & 0.019 & -0.137 & 0.104 & 0.134 & 0.257 \\
\hline External locus of control & 0.061 & 0.143 & -0.060 & -0.053 & -0.460 & -0.387 \\
\hline Positive reciprocity & -0.019 & 0.008 & 0.055 & 0.008 & 0.085 & 0.092 \\
\hline Negative reciprocity & 0.211 & -0.051 & 0.150 & -0.183 & 0.008 & -0.263 \\
\hline Risk taking & 0.220 & -0.138 & 0.139 & -0.177 & 0.406 & 0.044 \\
\hline \multicolumn{7}{|c|}{ (B) Other variables } \\
\hline Hourly wages (EUR2010) & 4.538 & 4.890 & 14.885 & 14.868 & 41.639 & 40.209 \\
\hline Age & 32.942 & 37.633 & 41.698 & 42.814 & 48.612 & 48.316 \\
\hline East Germany $(0 / 1)$ & 0.420 & 0.362 & 0.180 & 0.207 & 0.078 & 0.153 \\
\hline Married (0/1) & 0.304 & 0.528 & 0.646 & 0.627 & 0.810 & 0.674 \\
\hline Child under $16(0 / 1)$ & 0.331 & 0.413 & 0.403 & 0.362 & 0.448 & 0.366 \\
\hline Direct migration background $(0 / 1)$ & 0.088 & 0.106 & 0.178 & 0.103 & 0.057 & 0.051 \\
\hline Indirect migration background $(0 / 1)$ & 0.096 & 0.050 & 0.038 & 0.034 & 0.022 & 0.024 \\
\hline Tertiary degree & 0.072 & 0.089 & 0.118 & 0.211 & 0.675 & 0.749 \\
\hline Experience full time (years) & 10.010 & 8.194 & 19.864 & 13.517 & 23.349 & 17.059 \\
\hline Experience part time (years) & 0.865 & 4.734 & 0.446 & 5.523 & 0.592 & 5.270 \\
\hline Experience unemployment (years) & 0.991 & 1.150 & 0.441 & 0.415 & 0.128 & 0.204 \\
\hline Tenure (years) & 4.390 & 5.176 & 12.095 & 11.585 & 15.925 & 15.839 \\
\hline Full time employment $(0 / 1)$ & 0.409 & 0.260 & 0.971 & 0.582 & 0.976 & 0.639 \\
\hline Public employer (0/1) & 0.124 & 0.155 & 0.243 & 0.456 & 0.214 & 0.478 \\
\hline Firm size $<10$ & 0.271 & 0.341 & 0.095 & 0.097 & 0.093 & 0.134 \\
\hline Firm size 10-99 & 0.360 & 0.355 & 0.301 & 0.282 & 0.187 & 0.292 \\
\hline Firm size 100-199 & 0.078 & 0.060 & 0.084 & 0.098 & 0.067 & 0.063 \\
\hline Firm size 200-1999 & 0.155 & 0.131 & 0.276 & 0.291 & 0.244 & 0.135 \\
\hline Firm size $2000+$ & 0.136 & 0.112 & 0.245 & 0.231 & 0.410 & 0.376 \\
\hline Share female & \multicolumn{2}{|c|}{$63.54 \%$} & \multicolumn{2}{|c|}{$48.77 \%$} & \multicolumn{2}{|c|}{$23.74 \%$} \\
\hline
\end{tabular}

Notes: Descriptive statistics across the wage distributions; distribution is based on EUR2010 hourly wages. Source: SOEP v32 1991-2015, own calculations. 
Table A2: Occupations by gender.

\begin{tabular}{lcc}
\hline & Male (N=80,596) & Female (N=72,181) \\
& Share (in \%) & Share (in \%) \\
\hline Legislator/Senior government officals & 0.222 & 0.096 \\
Coporate managers & 5.463 & 2.186 \\
Manager of small enterprises & 2.285 & 1.204 \\
Science and engineering professionals & 8.737 & 2.106 \\
Life science and health professionals & 1.376 & 1.449 \\
Teaching professionals & 2.990 & 5.765 \\
Other professionals & 7.328 & 7.161 \\
Physical and engineering science associate professionals & 6.772 & 2.833 \\
Life science and health associate professionals & 1.112 & 6.772 \\
Teaching associate professionals & 0.766 & 4.108 \\
Other associate professionals & 8.678 & 17.506 \\
Office clerks & 6.317 & 14.777 \\
Customer services clerks & 0.649 & 3.094 \\
Personal and protective services workers & 3.109 & 10.627 \\
Models, salespersons and demonstrators & 1.280 & 6.531 \\
Skilled agricultural and fishery workers & 1.099 & 0.697 \\
Extraction and building trades workers & 9.081 & 0.831 \\
Metal, machinery and related trades workers & 11.312 & 0.639 \\
Precision, handicraft, craft printing and related trades workers & 1.370 & 0.899 \\
Other craft and related trades workers & 2.499 & 0.957 \\
Stationary plant and related operators & 1.990 & 0.270 \\
Machine operators and assemblers & 3.712 & 1.881 \\
Drivers and mobile plant operators & 5.755 & 0.434 \\
Sales and services elementary occupations & 2.004 & 5.249 \\
Agricultural, fishery and related labourers & 0.223 & 0.143 \\
Laborers in mining, construction, manufacturing and transport & 3.042 & 1.759 \\
Armed Forces & 0.828 & 0.026 \\
\hline Overall & 100.000 & 100.000 \\
\hline Notes & & \\
\hline
\end{tabular}

Notes: Occupations by gender. Source: SOEP v32 1991-2015, own calculations. 
Table A3: Industries by gender.

\begin{tabular}{lcc}
\hline & $\begin{array}{c}\text { Male }(\mathrm{N}=80,596) \\
\text { Share (in \%) }\end{array}$ & $\begin{array}{c}\text { Female }(\mathrm{N}=72,181) \\
\text { Share (in \%) }\end{array}$ \\
\hline Agriculture and fishing & 1.452 & 0.763 \\
Forestry & 0.279 & 0.083 \\
Mining and quarrying & 0.331 & 0.159 \\
Manufacturing & 32.964 & 14.156 \\
Electricity, gas and water supply & 1.582 & 0.536 \\
Construction & 9.799 & 1.618 \\
Wholesale and retail trade, repairs of personal goods & 9.012 & 15.274 \\
Hotels and restaurants & 1.504 & 2.983 \\
Transport, storage and communication & 6.806 & 3.599 \\
Finance & 4.614 & 4.803 \\
Real estate, renting and business activities & 7.490 & 8.499 \\
Public administration & 9.223 & 9.049 \\
Education & 4.649 & 11.162 \\
Health and social work & 4.773 & 20.557 \\
Other services & 3.965 & 5.375 \\
Activities of households & 1.472 & 1.336 \\
Extra-territorial organizations and bodies & 0.084 & 0.046 \\
\hline Overall & 100.000 & 100.000 \\
\hline
\end{tabular}

Notes: Industries by gender. Source: SOEP v32 1991-2015, own calculations. 
Table A4: Personality traits in the SOEP.

\begin{tabular}{|c|c|c|c|}
\hline Dimension & Items & Years surveyed & Cronbach's $\alpha$ \\
\hline \multirow{3}{*}{ Neuroticism } & I worry a lot & \multirow{3}{*}{$2005,2009,2013$} & \multirow{3}{*}{0.63} \\
\hline & I get nervous easily & & \\
\hline & I handle stress well (reversed) & & \\
\hline \multirow{3}{*}{ Openness to experience } & I am original, comes up with new ideas & \multirow{3}{*}{$2005,2009,2013$} & \multirow{3}{*}{0.59} \\
\hline & I value artistic expression & & \\
\hline & I have an active imagination & & \\
\hline \multirow{3}{*}{ Extraversion } & I am communicative & \multirow{3}{*}{$2005,2009,2013$} & \multirow{3}{*}{0.64} \\
\hline & I am sociable & & \\
\hline & I am reserved (reversed) & & \\
\hline \multirow{3}{*}{ Conscientiousness } & I do a thorough job & \multirow{3}{*}{$2005,2009,2013$} & \multirow{3}{*}{0.57} \\
\hline & I do thing effectively/efficiently & & \\
\hline & I tend to be lazy (reversed) & & \\
\hline \multirow{3}{*}{ Agreeableness } & I am sometimes too coarse with others (reversed) & \multirow{3}{*}{$2005,2009,2013$} & \multirow{3}{*}{0.49} \\
\hline & I have a forgiving nature & & \\
\hline & I friendly with others & & \\
\hline \multirow{8}{*}{ Locus of control } & What you achieve depends on luck & \multirow{8}{*}{$2005,2010,2015$} & \multirow{8}{*}{0.60} \\
\hline & Others make the crucial decisions in my life & & \\
\hline & Possibilities are defined by social conditions & & \\
\hline & Little control over my life & & \\
\hline & Abilities are more important than effort & & \\
\hline & How Life Proceeds Depends On Me & & \\
\hline & You Have To Work Hard For Success & & \\
\hline & In Case Of Difficulties Doubts About Own Abilities & & \\
\hline \multirow{3}{*}{ Positive Reciprocity } & Return favors & \multirow{3}{*}{$2005,2010,2015$} & \multirow{3}{*}{0.62} \\
\hline & Help those who help me & & \\
\hline & Help those who have helped me in the past & & \\
\hline \multirow{3}{*}{ Negative Reciprocity } & Get revenge for severe injustices & \multirow{3}{*}{$2005,2010,2015$} & \multirow{3}{*}{0.82} \\
\hline & $\begin{array}{l}\text { Cause similar problems to those who cause me } \\
\text { problems }\end{array}$ & & \\
\hline & Insult those who insult me & & \\
\hline Risk taking & Personal willingness to take risks & $\begin{array}{l}2004,2006 \\
2008-2015\end{array}$ & \\
\hline
\end{tabular}

Source: SOEP v32 1991-2015, own calculations. 
Table A5: Regression results for decomposition at the mean (corresponding to Tab 4, columns 1 to 4$)$.

\begin{tabular}{|c|c|c|c|}
\hline & Females $(\mathrm{N}=72,181)$ & Males $(\mathrm{N}=80,596)$ & Pooled (N=152,777) \\
\hline Female & & & $\begin{array}{c}-0.106^{* * *} \\
(0.007)\end{array}$ \\
\hline Extraversion & $\begin{array}{l}-0.003 \\
(0.004)\end{array}$ & $\begin{array}{l}-0.003 \\
(0.004)\end{array}$ & $\begin{array}{l}-0.004 \\
(0.003)\end{array}$ \\
\hline Agreeableness & $\begin{array}{c}-0.013^{* *} \\
(0.004)\end{array}$ & $\begin{array}{c}-0.027^{* * *} \\
(0.004)\end{array}$ & $\begin{array}{c}-0.020^{* * *} * \\
(0.003)\end{array}$ \\
\hline Conscientiousness & $\begin{array}{l}-0.006 \\
(0.004)\end{array}$ & $\begin{array}{c}-0.010^{* *} \\
(0.004)\end{array}$ & $\begin{array}{c}-0.007^{*} \\
(0.003)\end{array}$ \\
\hline Neuroticism & $\begin{array}{r}-0.006^{+} \\
(0.004)\end{array}$ & $\begin{array}{c}-0.014^{* * *} \\
(0.004)\end{array}$ & $\begin{array}{c}-0.008^{* *} \\
(0.003)\end{array}$ \\
\hline Openness & $\begin{array}{c}0.004 \\
(0.004)\end{array}$ & $\begin{array}{c}0.018^{* * *} \\
(0.004)\end{array}$ & $\begin{array}{c}0.011^{* * *} \\
(0.003)\end{array}$ \\
\hline External locus of control & $\begin{array}{c}-0.032^{* * *} \\
(0.004)\end{array}$ & $\begin{array}{c}-0.049^{* * *} \\
(0.004)\end{array}$ & $\begin{array}{c}-0.043^{* * *} \\
(0.003)\end{array}$ \\
\hline Positive reciprocity & $\begin{array}{c}0.005 \\
(0.004)\end{array}$ & $\begin{array}{c}0.013^{* * * *} \\
(0.004)\end{array}$ & $\begin{array}{c}0.009^{* *} \\
(0.003)\end{array}$ \\
\hline Negative reciprocity & $\begin{array}{c}-0.012^{* *} \\
(0.004)\end{array}$ & $\begin{array}{l}-0.002 \\
(0.004)\end{array}$ & $\begin{array}{l}-0.006^{*} \\
(0.003)\end{array}$ \\
\hline Risk taking & $\begin{array}{c}0.002 \\
(0.003)\end{array}$ & $\begin{array}{c}0.013^{* * *} \\
(0.003)\end{array}$ & $\begin{array}{c}0.008^{* * * *} \\
(0.002)\end{array}$ \\
\hline East Germany $(0 / 1)$ & $\begin{array}{c}-0.334^{* * *} \\
(0.010)\end{array}$ & $\begin{array}{c}-0.399^{* * *} \\
(0.010)\end{array}$ & $\begin{array}{c}-0.374^{* * *} \\
(0.007)\end{array}$ \\
\hline Married (0/1) & $\begin{array}{c}0.002 \\
(0.008)\end{array}$ & $\begin{array}{c}0.059^{* * *} \\
(0.008)\end{array}$ & $\begin{array}{c}0.042^{* * *} \\
(0.006)\end{array}$ \\
\hline Age & $\begin{array}{c}0.062^{* * *} \\
(0.002)\end{array}$ & $\begin{array}{c}0.057^{* * *} \\
(0.003)\end{array}$ & $\begin{array}{c}0.063^{* * *} \\
(0.002)\end{array}$ \\
\hline $\mathrm{Age}^{2} / 100$ & $\begin{array}{c}-0.069^{* * *} \\
(0.003)\end{array}$ & $\begin{array}{c}-0.053^{* * *} \\
(0.003)\end{array}$ & $\begin{array}{c}-0.067^{* * *} \\
(0.002)\end{array}$ \\
\hline Experience full time (years) & $\begin{array}{l}0.004^{* * *} \\
(0.001)\end{array}$ & $\begin{array}{c}-0.004^{* *} \\
(0.001)\end{array}$ & $\begin{array}{l}0.002^{*} \\
(0.001)\end{array}$ \\
\hline Experience part time (years) & $\begin{array}{c}0.004^{* * *} \\
(0.001)\end{array}$ & $\begin{array}{c}0.004 \\
(0.002)\end{array}$ & $\begin{array}{c}0.005^{* * *} \\
(0.001)\end{array}$ \\
\hline Experience unemployment (years) & $\begin{array}{c}-0.038^{* * *} \\
(0.003)\end{array}$ & $\begin{array}{c}-0.045^{* * *} \\
(0.003)\end{array}$ & $\begin{array}{c}-0.041^{* * *} \\
(0.002)\end{array}$ \\
\hline Public employer $(0 / 1)$ & $\begin{array}{c}0.087^{* * *} \\
(0.008)\end{array}$ & $\begin{array}{c}-0.113^{* * *} \\
(0.008)\end{array}$ & $\begin{array}{c}-0.010^{+} \\
(0.006)\end{array}$ \\
\hline Tenure (years) & $\begin{array}{c}0.009^{* * *} \\
(0.001)\end{array}$ & $\begin{array}{c}0.006^{* * * *} \\
(0.000)\end{array}$ & $\begin{array}{c}0.007^{* * *} \\
(0.000)\end{array}$ \\
\hline Firm size $10-99$ & $\begin{array}{c}0.151^{* * * *} \\
(0.012)\end{array}$ & $\begin{array}{c}0.124^{* * * *} \\
(0.012)\end{array}$ & $\begin{array}{c}0.143^{* * *} * \\
(0.009)\end{array}$ \\
\hline Firm size $100-199$ & $\begin{array}{c}0.219^{* * *} \\
(0.015)\end{array}$ & $\begin{array}{c}0.190^{* * *} \\
(0.016)\end{array}$ & $\begin{array}{c}0.213^{* * *} \\
(0.011)\end{array}$ \\
\hline Firm size 200-1999 & $\begin{array}{c}0.255^{* * * *} \\
(0.013)\end{array}$ & $\begin{array}{c}0.258^{* * * *} \\
(0.014)\end{array}$ & $\begin{array}{c}0.265^{* * *} \\
(0.009)\end{array}$ \\
\hline Firm size 2000+ & $\begin{array}{c}0.317^{* * *} \\
(0.013)\end{array}$ & $\begin{array}{c}0.306^{* * *} \\
(0.014)\end{array}$ & $\begin{array}{c}0.315^{* * *} \\
(0.010)\end{array}$ \\
\hline Child under $16(0 / 1)$ & $\begin{array}{c}0.029^{* * *} \\
(0.007)\end{array}$ & $\begin{array}{c}0.041^{* * *} \\
(0.007)\end{array}$ & $\begin{array}{c}0.050^{* * *} \\
(0.005)\end{array}$ \\
\hline Indirect migration background & $\begin{array}{c}0.012 \\
(0.017)\end{array}$ & $\begin{array}{c}0.004 \\
(0.018)\end{array}$ & $\begin{array}{c}0.010 \\
(0.013)\end{array}$ \\
\hline Direct migration background & $\begin{array}{c}-0.075^{* * *} \\
(0.013)\end{array}$ & $\begin{array}{c}-0.061^{* * *} \\
(0.012)\end{array}$ & $\begin{array}{c}-0.060^{* * *} \\
(0.009)\end{array}$ \\
\hline Full time employment $(0 / 1)$ & $\begin{array}{c}0.191^{* * *} \\
(0.008)\end{array}$ & $\begin{array}{c}0.593^{* * *} \\
(0.018)\end{array}$ & $\begin{array}{c}0.303^{* * *} \\
(0.008)\end{array}$ \\
\hline CASMIN General elementary (1b) & $\begin{array}{c}0.022 \\
(0.033)\end{array}$ & $\begin{array}{c}0.022 \\
(0.038)\end{array}$ & $\begin{array}{c}0.022 \\
(0.029)\end{array}$ \\
\hline CASMIN Basic vocational (1c) & $\begin{array}{c}0.136^{* * *} \\
(0.033)\end{array}$ & $\begin{array}{c}0.117^{* *} \\
(0.037)\end{array}$ & $\begin{array}{c}0.147^{* * *} \\
(0.029)\end{array}$ \\
\hline CASMIN Intermediate general (2b) & $\begin{array}{c}0.033 \\
(0.037)\end{array}$ & $\begin{array}{c}0.046 \\
(0.042)\end{array}$ & $\begin{array}{c}0.033 \\
(0.031)\end{array}$ \\
\hline CASMIN Intermediate vocational (2a) & $\begin{array}{c}0.287^{* * *} \\
(0.034)\end{array}$ & $\begin{array}{c}0.210^{* * *} * \\
(0.038)\end{array}$ & $\begin{array}{c}0.272 * * * \\
(0.029)\end{array}$ \\
\hline CASMIN General maturity (2c_gen) & $\begin{array}{c}0.007 \\
(0.041)\end{array}$ & $\begin{array}{c}0.120^{* *} \\
(0.046)\end{array}$ & $\begin{array}{c}0.062^{+} \\
(0.034)\end{array}$ \\
\hline CASMIN Vocational maturity (2c_voc) & $\begin{array}{c}0.387^{* * *} * \\
(0.035)\end{array}$ & $\begin{array}{c}0.322 * * * \\
(0.040)\end{array}$ & $\begin{array}{c}0.380 * * * \\
(0.030)\end{array}$ \\
\hline CASMIN Lower tertiarty (3a) & $\begin{array}{c}0.482 * * * \\
(0.036)\end{array}$ & $\begin{array}{c}0.481^{* * *} * \\
(0.041)\end{array}$ & $\begin{array}{c}0.519^{* * *} \\
(0.030)\end{array}$ \\
\hline CASMIN Higher tertiary (3b) & $\begin{array}{c}0.628^{* * *} \\
(0.036)\end{array}$ & $\begin{array}{c}0.607^{* * *} * \\
(0.040)\end{array}$ & $\begin{array}{c}0.653 * * * \\
(0.030)\end{array}$ \\
\hline Constant & $\begin{array}{r}-0.109^{+} \\
(0.060)\end{array}$ & $\begin{array}{l}-0.065 \\
(0.058)\end{array}$ & $\begin{array}{l}-0.036 \\
(0.044)\end{array}$ \\
\hline$R^{2}$ & 0.490 & 0.578 & 0.544 \\
\hline
\end{tabular}


Table A6: Regression results for decomposition at the 10th percentile (corresponding to Tab 4, columns 1 to 4 ).

\begin{tabular}{|c|c|c|c|}
\hline & Females $(\mathrm{N}=72,181)$ & Males $(\mathrm{N}=80,596)$ & Pooled $(\mathrm{N}=152,777)$ \\
\hline Female & & & $\begin{array}{c}0.003 \\
(0.014)\end{array}$ \\
\hline Extraversion & $\begin{array}{l}-0.011 \\
(0.010)\end{array}$ & $\begin{array}{l}-0.009 \\
(0.006)\end{array}$ & $\begin{array}{l}-0.007 \\
(0.006)\end{array}$ \\
\hline Agreeableness & $\begin{array}{r}0.019^{+} \\
(0.011)\end{array}$ & $\begin{array}{c}-0.020^{* * *} \\
(0.006)\end{array}$ & $\begin{array}{l}-0.005 \\
(0.006)\end{array}$ \\
\hline Conscientiousness & $\begin{array}{l}-0.014 \\
(0.011)\end{array}$ & $\begin{array}{l}-0.002 \\
(0.006)\end{array}$ & $\begin{array}{l}-0.003 \\
(0.006)\end{array}$ \\
\hline Neuroticism & $\begin{array}{l}-0.002 \\
(0.010)\end{array}$ & $\begin{array}{l}-0.014^{*} \\
(0.006)\end{array}$ & $\begin{array}{l}-0.005 \\
(0.006)\end{array}$ \\
\hline Openness & $\begin{array}{l}-0.004 \\
(0.010)\end{array}$ & $\begin{array}{l}0.012^{*} \\
(0.006)\end{array}$ & $\begin{array}{c}0.003 \\
(0.006)\end{array}$ \\
\hline External locus of control & $\begin{array}{c}-0.047^{* * *} \\
(0.011)\end{array}$ & $\begin{array}{c}-0.029^{* * *} \\
(0.007)\end{array}$ & $\begin{array}{c}-0.041^{* * *} \\
(0.006)\end{array}$ \\
\hline Positive reciprocity & $\begin{array}{c}0.000 \\
(0.010)\end{array}$ & $\begin{array}{c}0.022^{* *} \\
(0.007)\end{array}$ & $\begin{array}{c}0.010 \\
(0.006)\end{array}$ \\
\hline Negative reciprocity & $\begin{array}{l}-0.010 \\
(0.012)\end{array}$ & $\begin{array}{l}-0.008 \\
(0.006)\end{array}$ & $\begin{array}{l}-0.008 \\
(0.006)\end{array}$ \\
\hline Risk taking & $\begin{array}{r}-0.016^{+} \\
(0.009)\end{array}$ & $\begin{array}{r}-0.010^{+} \\
(0.005)\end{array}$ & $\begin{array}{c}-0.015^{* *} \\
(0.005)\end{array}$ \\
\hline East Germany (0/1) & $\begin{array}{l}-0.541^{* * *} \\
(0.027)\end{array}$ & $\begin{array}{l}-0.340^{* * *} \\
(0.019)\end{array}$ & $\begin{array}{l}-0.444^{* * *} \\
(0.017)\end{array}$ \\
\hline Married $(0 / 1)$ & $\begin{array}{c}0.015 \\
(0.019)\end{array}$ & $\begin{array}{c}0.035^{* *} \\
(0.013)\end{array}$ & $\begin{array}{c}0.036^{* *} \\
(0.012)\end{array}$ \\
\hline Age & $\begin{array}{l}0.161^{* * *} \\
(0.007)\end{array}$ & $\begin{array}{c}0.111^{* * *} \\
(0.005)\end{array}$ & $\begin{array}{l}0.157^{* * *} \\
(0.004)\end{array}$ \\
\hline $\mathrm{Age}^{2} / 100$ & $\begin{array}{c}-0.185^{* * *} \\
(0.008)\end{array}$ & $\begin{array}{c}-0.118^{* * *} \\
(0.005)\end{array}$ & $\begin{array}{c}-0.177^{* * *} \\
(0.005)\end{array}$ \\
\hline Experience full time (years) & $\begin{array}{r}0.006^{* *} \\
(0.002)\end{array}$ & $\begin{array}{l}-0.002 \\
(0.002)\end{array}$ & $\begin{array}{c}0.003^{+} \\
(0.002)\end{array}$ \\
\hline Experience part time (years) & $\begin{array}{c}0.022^{* * *} \\
(0.003)\end{array}$ & $\begin{array}{c}0.055^{* * *} \\
(0.005)\end{array}$ & $\begin{array}{c}0.030^{* * * *} \\
(0.002)\end{array}$ \\
\hline Experience unemployment (years) & $\begin{array}{l}-0.081^{* * * *} \\
(0.009)\end{array}$ & $\begin{array}{c}-0.025^{* * *} \\
(0.007)\end{array}$ & $\begin{array}{c}-0.060^{* * *} \\
(0.006)\end{array}$ \\
\hline Public employer (0/1) & $\begin{array}{c}0.179^{* * *} \\
(0.017)\end{array}$ & $\begin{array}{c}0.011 \\
(0.011)\end{array}$ & $\begin{array}{c}0.105^{* * * *} \\
(0.011)\end{array}$ \\
\hline Tenure (years) & $\begin{array}{c}0.007^{* * *} \\
(0.001)\end{array}$ & $\begin{array}{c}0.002^{* * * *} \\
(0.001)\end{array}$ & $\begin{array}{c}0.004^{* * *} \\
(0.001)\end{array}$ \\
\hline Firm size $10-99$ & $\begin{array}{c}0.395^{* * * *} \\
(0.035)\end{array}$ & $\begin{array}{c}0.286^{* * * *} \\
(0.028)\end{array}$ & $\begin{array}{c}0.353^{* * * *} \\
(0.023)\end{array}$ \\
\hline Firm size 100-199 & $\begin{array}{c}0.526^{* * * *} \\
(0.040)\end{array}$ & $\begin{array}{c}0.321^{* * * *} \\
(0.031)\end{array}$ & $\begin{array}{c}0.429^{* * * *} \\
(0.026)\end{array}$ \\
\hline Firm size 200-1999 & $\begin{array}{c}0.599^{* * *} \\
(0.035)\end{array}$ & $\begin{array}{c}0.365^{* * *} * \\
(0.028)\end{array}$ & $\begin{array}{c}0.477^{* * * *} \\
(0.023)\end{array}$ \\
\hline Firm size $2000+$ & $\begin{array}{c}0.593^{* * *} \\
(0.035)\end{array}$ & $\begin{array}{c}0.373^{* * *} \\
(0.028)\end{array}$ & $\begin{array}{c}0.477^{* * * *} \\
(0.023)\end{array}$ \\
\hline Child under $16(0 / 1)$ & $\begin{array}{l}-0.005 \\
(0.020)\end{array}$ & $\begin{array}{c}-0.057^{* * *} \\
(0.012)\end{array}$ & $\begin{array}{l}-0.014 \\
(0.011)\end{array}$ \\
\hline Indirect migration background & $\begin{array}{l}0.091^{*} \\
(0.045)\end{array}$ & $\begin{array}{l}-0.004 \\
(0.030)\end{array}$ & $\begin{array}{c}0.040 \\
(0.028)\end{array}$ \\
\hline Direct migration background & $\begin{array}{c}0.051 \\
(0.034)\end{array}$ & $\begin{array}{c}0.053^{* * *} \\
(0.018)\end{array}$ & $\begin{array}{c}0.080^{* * * *} \\
(0.019)\end{array}$ \\
\hline Full time employment $(0 / 1)$ & $\begin{array}{c}0.636^{* * *} \\
(0.023)\end{array}$ & $\begin{array}{c}1.867 * * * \\
(0.047)\end{array}$ & $\begin{array}{c}0.932 * * * \\
(0.021)\end{array}$ \\
\hline CASMIN General elementary (1b) & $\begin{array}{c}0.047 \\
(0.103)\end{array}$ & $\begin{array}{c}0.093 \\
(0.075)\end{array}$ & $\begin{array}{c}0.069 \\
(0.069)\end{array}$ \\
\hline CASMIN Basic vocational (1c) & $\begin{array}{r}0.289^{* *} \\
(0.100)\end{array}$ & $\begin{array}{c}0.286^{* * *} * \\
(0.071)\end{array}$ & $\begin{array}{l}0.337^{* * *} \\
(0.066)\end{array}$ \\
\hline CASMIN Intermediate general ( $2 b$ ) & $\begin{array}{r}-0.283^{*} \\
(0.114)\end{array}$ & $\begin{array}{r}-0.222^{*} \\
(0.090)\end{array}$ & $\begin{array}{c}-0.303^{* * *} \\
(0.078)\end{array}$ \\
\hline CASMIN Intermediate vocational (2a) & $\begin{array}{c}0.509^{* * *} \\
(0.099)\end{array}$ & $\begin{array}{c}0.305^{* * * *} \\
(0.073)\end{array}$ & $\begin{array}{c}0.448^{* * * *} \\
(0.066)\end{array}$ \\
\hline CASMIN General maturity (2c_gen) & $\begin{array}{c}-0.595^{* * *} \\
(0.124)\end{array}$ & $\begin{array}{c}-0.205^{*} \\
(0.095)\end{array}$ & $\begin{array}{c}-0.459^{* * *} \\
(0.082)\end{array}$ \\
\hline CASMIN Vocational maturity (2c_voc) & $\begin{array}{c}0.629^{* * *} \\
(0.101)\end{array}$ & $\begin{array}{c}0.337^{* * *} \\
(0.074)\end{array}$ & $\begin{array}{c}0.526^{* * * *} \\
(0.067)\end{array}$ \\
\hline CASMIN Lower tertiarty (3a) & $\begin{array}{c}0.662^{* * *} \\
(0.101)\end{array}$ & $\begin{array}{c}0.323^{* * *} \\
(0.074)\end{array}$ & $\begin{array}{c}0.504^{* * *} \\
(0.067)\end{array}$ \\
\hline CASMIN Higher tertiary (3b) & $\begin{array}{c}0.613^{* * *} \\
(0.099)\end{array}$ & $\begin{array}{c}0.340^{* * *} \\
(0.075)\end{array}$ & $\begin{array}{c}0.508^{* * * *} \\
(0.066)\end{array}$ \\
\hline Constant & $\begin{array}{c}-4.468^{* * *} \\
(0.180)\end{array}$ & $\begin{array}{c}-3.574^{* * *} \\
(0.129)\end{array}$ & $\begin{array}{c}-4.117^{* * *} \\
(0.114)\end{array}$ \\
\hline$R^{2}$ & 0.244 & 0.376 & 0.279 \\
\hline
\end{tabular}

$p<0.05,{ }^{* *} p<0.01,{ }^{* * *} p<0.001$. Source: SOEP v32 1991-2015, own calculations. 
Table A7: Regression results for decomposition at the 50th percentile (corresponding to Tab 4, columns 1 to 4 ).

\begin{tabular}{|c|c|c|c|}
\hline & Females $(\mathrm{N}=72,181)$ & Males $(\mathrm{N}=80,596)$ & Pooled (N=152,777) \\
\hline Female & & & $\begin{array}{c}-0.132^{* * *} \\
(0.007)\end{array}$ \\
\hline Extraversion & $\begin{array}{l}-0.006 \\
(0.004)\end{array}$ & $\begin{array}{l}-0.005 \\
(0.004)\end{array}$ & $\begin{array}{c}-0.006^{+} \\
(0.003)\end{array}$ \\
\hline Agreeableness & $\begin{array}{c}-0.018^{* * *} \\
(0.004)\end{array}$ & $\begin{array}{c}-0.023 * * * \\
(0.004)\end{array}$ & $\begin{array}{c}-0.020^{* * *} \\
(0.003)\end{array}$ \\
\hline Conscientiousness & $\begin{array}{l}-0.007 \\
(0.005)\end{array}$ & $\begin{array}{c}-0.016^{* * *} \\
(0.004)\end{array}$ & $\begin{array}{c}-0.011^{* * *} \\
(0.003)\end{array}$ \\
\hline Neuroticism & $\begin{array}{r}-0.007^{+} \\
(0.004)\end{array}$ & $\begin{array}{c}-0.010^{*} \\
(0.004)\end{array}$ & $\begin{array}{c}-0.007^{*} \\
(0.003)\end{array}$ \\
\hline Openness & $\begin{array}{l}0.008^{+} \\
(0.004)\end{array}$ & $\begin{array}{c}0.018^{* * *} \\
(0.004)\end{array}$ & $\begin{array}{c}0.013^{* * *} \\
(0.003)\end{array}$ \\
\hline External locus of control & $\begin{array}{c}-0.021^{* * *} \\
(0.004)\end{array}$ & $\begin{array}{c}-0.034^{* * * *} \\
(0.004)\end{array}$ & $\begin{array}{c}-0.029^{* * *} \\
(0.003)\end{array}$ \\
\hline Positive reciprocity & $\begin{array}{l}0.010^{*} \\
(0.004)\end{array}$ & $\begin{array}{c}0.006 \\
(0.004)\end{array}$ & $\begin{array}{l}0.008^{*} \\
(0.003)\end{array}$ \\
\hline Negative reciprocity & $\begin{array}{c}-0.014^{* *} \\
(0.005)\end{array}$ & $\begin{array}{c}-0.001 \\
(0.004)\end{array}$ & $\begin{array}{c}-0.007^{*} \\
(0.003)\end{array}$ \\
\hline Risk taking & $\begin{array}{l}0.006^{+} \\
(0.004)\end{array}$ & $\begin{array}{c}0.013^{* * *} * \\
(0.004)\end{array}$ & $\begin{array}{c}0.011^{* * *} \\
(0.003)\end{array}$ \\
\hline East Germany $(0 / 1)$ & $\begin{array}{c}-0.285^{* * *} \\
(0.011)\end{array}$ & $\begin{array}{c}-0.396^{* * *} \\
(0.011)\end{array}$ & $\begin{array}{c}-0.342^{* * *} \\
(0.008)\end{array}$ \\
\hline Married $(0 / 1)$ & $\begin{array}{c}-0.022^{*} \\
(0.009)\end{array}$ & $\begin{array}{c}0.050^{* * *} \\
(0.009)\end{array}$ & $\begin{array}{c}0.020^{* *} \\
(0.006)\end{array}$ \\
\hline Age & $\begin{array}{c}0.043^{* * *} \\
(0.003)\end{array}$ & $\begin{array}{c}0.058^{* * *} * \\
(0.003)\end{array}$ & $\begin{array}{c}0.050^{* * *} \\
(0.002)\end{array}$ \\
\hline $\mathrm{Age}^{2} / 100$ & $\begin{array}{c}-0.049^{* * *} \\
(0.003)\end{array}$ & $\begin{array}{c}-0.061^{* * *} \\
(0.003)\end{array}$ & $\begin{array}{c}-0.057^{* * *} \\
(0.002)\end{array}$ \\
\hline Experience full time (years) & $\begin{array}{c}0.004^{* * *} \\
(0.001)\end{array}$ & $\begin{array}{c}-0.002 \\
(0.001)\end{array}$ & $\begin{array}{c}0.003^{* * *} \\
(0.001)\end{array}$ \\
\hline Experience part time (years) & $\begin{array}{l}-0.001 \\
(0.001)\end{array}$ & $\begin{array}{c}-0.006^{* *} \\
(0.002)\end{array}$ & $\begin{array}{l}-0.000 \\
(0.001)\end{array}$ \\
\hline Experience unemployment (years) & $\begin{array}{c}-0.027^{* * *} \\
(0.002)\end{array}$ & $\begin{array}{c}-0.049^{* * *} * \\
(0.003)\end{array}$ & $\begin{array}{c}-0.033^{* * *} \\
(0.002)\end{array}$ \\
\hline Public employer (0/1) & $\begin{array}{c}0.117^{* * * *} \\
(0.009)\end{array}$ & $\begin{array}{c}-0.044^{* * *} \\
(0.009)\end{array}$ & $\begin{array}{c}0.041^{* * * *} \\
(0.006)\end{array}$ \\
\hline Tenure (years) & $\begin{array}{c}0.011^{* * *} \\
(0.001)\end{array}$ & $\begin{array}{c}0.008^{* * *} \\
(0.000)\end{array}$ & $\begin{array}{c}0.010^{* * *} \\
(0.000)\end{array}$ \\
\hline Firm size $10-99$ & $\begin{array}{c}0.110^{* * *} \\
(0.010)\end{array}$ & $\begin{array}{c}0.110^{* * *} \\
(0.012)\end{array}$ & $\begin{array}{c}0.114 * * * \\
(0.008)\end{array}$ \\
\hline Firm size 100-199 & $\begin{array}{c}0.194^{* * *} \\
(0.015)\end{array}$ & $\begin{array}{c}0.204^{* * *} \\
(0.016)\end{array}$ & $\begin{array}{c}0.205^{* * *} \\
(0.011)\end{array}$ \\
\hline Firm size 200-1999 & $\begin{array}{c}0.228^{* * *} \\
(0.013)\end{array}$ & $\begin{array}{c}0.276^{* * * *} \\
(0.013)\end{array}$ & $\begin{array}{c}0.260^{* * * *} \\
(0.009)\end{array}$ \\
\hline Firm size $2000+$ & $\begin{array}{c}0.274^{* * *} \\
(0.013)\end{array}$ & $\begin{array}{c}0.299^{* * *} \\
(0.013)\end{array}$ & $\begin{array}{c}0.289^{* * * *} \\
(0.009)\end{array}$ \\
\hline Child under $16(0 / 1)$ & $\begin{array}{c}0.022^{* * *} \\
(0.008)\end{array}$ & $\begin{array}{c}0.034^{* * *} \\
(0.008)\end{array}$ & $\begin{array}{c}0.041^{* * * *} \\
(0.006)\end{array}$ \\
\hline Indirect migration background & $\begin{array}{l}-0.015 \\
(0.020)\end{array}$ & $\begin{array}{c}0.016 \\
(0.018)\end{array}$ & $\begin{array}{c}0.003 \\
(0.014)\end{array}$ \\
\hline Direct migration background & $\begin{array}{c}-0.128^{* * *} \\
(0.014)\end{array}$ & $\begin{array}{c}-0.090^{* * *} \\
(0.015)\end{array}$ & $\begin{array}{c}-0.101^{* * *} \\
(0.011)\end{array}$ \\
\hline Full time employment $(0 / 1)$ & $\begin{array}{c}0.063^{* * *} \\
(0.009)\end{array}$ & $\begin{array}{c}0.194^{* * *} \\
(0.012)\end{array}$ & $\begin{array}{c}0.119^{* * *} \\
(0.007)\end{array}$ \\
\hline CASMIN General elementary (1b) & $\begin{array}{l}-0.012 \\
(0.028)\end{array}$ & $\begin{array}{l}-0.011 \\
(0.034)\end{array}$ & $\begin{array}{l}-0.013 \\
(0.023)\end{array}$ \\
\hline CASMIN Basic vocational (1c) & $\begin{array}{l}0.069^{*} \\
(0.028)\end{array}$ & $\begin{array}{l}0.079^{*} \\
(0.032)\end{array}$ & $\begin{array}{c}0.095^{* * *} \\
(0.023)\end{array}$ \\
\hline CASMIN Intermediate general ( $2 \mathrm{~b})$ & $\begin{array}{c}0.137^{* * *} \\
(0.031)\end{array}$ & $\begin{array}{l}0.079^{*} \\
(0.037)\end{array}$ & $\begin{array}{c}0.109^{* * *} \\
(0.025)\end{array}$ \\
\hline CASMIN Intermediate vocational (2a) & $\begin{array}{c}0.233^{* * *} \\
(0.028)\end{array}$ & $\begin{array}{c}0.133^{* * *} \\
(0.033)\end{array}$ & $\begin{array}{c}0.194^{* * *} \\
(0.023)\end{array}$ \\
\hline CASMIN General maturity (2c_gen) & $\begin{array}{c}0.121^{* * * *} \\
(0.034)\end{array}$ & $\begin{array}{l}0.066^{+} \\
(0.039)\end{array}$ & $\begin{array}{c}0.106^{* * * *} \\
(0.027)\end{array}$ \\
\hline CASMIN Vocational maturity (2c_voc) & $\begin{array}{c}0.353^{* * *} \\
(0.030)\end{array}$ & $\begin{array}{c}0.261^{* * *} \\
(0.035)\end{array}$ & $\begin{array}{c}0.322 * * * \\
(0.024)\end{array}$ \\
\hline CASMIN Lower tertiarty (3a) & $\begin{array}{c}0.486^{* * *} \\
(0.032)\end{array}$ & $\begin{array}{c}0.382^{* * *} \\
(0.035)\end{array}$ & $\begin{array}{c}0.460^{* * *} \\
(0.025)\end{array}$ \\
\hline CASMIN Higher tertiary (3b) & $\begin{array}{c}0.574 * * * \\
(0.029)\end{array}$ & $\begin{array}{c}0.449^{* * *} \\
(0.035)\end{array}$ & $\begin{array}{c}0.538^{* * *} \\
(0.023)\end{array}$ \\
\hline Constant & $\begin{array}{c}0.711^{* * *} \\
(0.056)\end{array}$ & $\begin{array}{c}0.463^{* * *} \\
(0.058)\end{array}$ & $\begin{array}{c}0.665^{* * *} \\
(0.040)\end{array}$ \\
\hline$R^{2}$ & 0.374 & 0.410 & 0.407 \\
\hline
\end{tabular}


Table A8: Regression results for decomposition at the 90th percentile (corresponding to Tab 4, columns 1 to 4 ).

\begin{tabular}{|c|c|c|c|}
\hline & Females $(\mathrm{N}=72,181)$ & Males $(\mathrm{N}=80,596)$ & Pooled (N=152,777) \\
\hline Female & & & $\begin{array}{c}-0.167^{* * *} \\
(0.013)\end{array}$ \\
\hline Extraversion & $\begin{array}{c}0.001 \\
(0.007)\end{array}$ & $\begin{array}{c}0.001 \\
(0.009)\end{array}$ & $\begin{array}{l}-0.005 \\
(0.006)\end{array}$ \\
\hline Agreeableness & $\begin{array}{c}-0.029^{* * * *} \\
(0.006)\end{array}$ & $\begin{array}{c}-0.043^{* * *} \\
(0.009)\end{array}$ & $\begin{array}{c}-0.032^{* * *} \\
(0.006)\end{array}$ \\
\hline Conscientiousness & $\begin{array}{c}0.002 \\
(0.007)\end{array}$ & $\begin{array}{l}-0.000 \\
(0.009)\end{array}$ & $\begin{array}{c}0.001 \\
(0.006)\end{array}$ \\
\hline Neuroticism & $\begin{array}{r}-0.010^{+} \\
(0.006)\end{array}$ & $\begin{array}{c}-0.023^{* *} \\
(0.009)\end{array}$ & $\begin{array}{c}-0.015^{* *} \\
(0.005)\end{array}$ \\
\hline Openness & $\begin{array}{l}-0.003 \\
(0.006)\end{array}$ & $\begin{array}{l}0.020^{*} \\
(0.009)\end{array}$ & $\begin{array}{l}0.010^{+} \\
(0.006)\end{array}$ \\
\hline External locus of control & $\begin{array}{c}-0.034^{* * *} \\
(0.006)\end{array}$ & $\begin{array}{c}-0.077^{* * *} \\
(0.009)\end{array}$ & $\begin{array}{c}-0.059^{* * *} \\
(0.006)\end{array}$ \\
\hline Positive reciprocity & $\begin{array}{c}0.009 \\
(0.006)\end{array}$ & $\begin{array}{c}0.023^{* *} \\
(0.009)\end{array}$ & $\begin{array}{c}0.016^{* *} \\
(0.006)\end{array}$ \\
\hline Negative reciprocity & $\begin{array}{l}-0.001 \\
(0.006)\end{array}$ & $\begin{array}{l}-0.005 \\
(0.008)\end{array}$ & $\begin{array}{l}-0.002 \\
(0.005)\end{array}$ \\
\hline Risk taking & $\begin{array}{l}0.010^{+} \\
(0.005)\end{array}$ & $\begin{array}{c}0.031^{* * * *} \\
(0.008)\end{array}$ & $\begin{array}{c}0.024^{* * * *} \\
(0.005)\end{array}$ \\
\hline East Germany (0/1) & $\begin{array}{c}-0.181^{* * *} \\
(0.016)\end{array}$ & $\begin{array}{c}-0.405^{* * *} \\
(0.021)\end{array}$ & $\begin{array}{c}-0.315^{* * *} \\
(0.013)\end{array}$ \\
\hline Married (0/1) & $\begin{array}{c}0.005 \\
(0.014)\end{array}$ & $\begin{array}{c}0.073^{* * *} \\
(0.019)\end{array}$ & $\begin{array}{c}0.063^{* * *} \\
(0.012)\end{array}$ \\
\hline Age & $\begin{array}{c}-0.009^{* *} \\
(0.004)\end{array}$ & $\begin{array}{c}0.003 \\
(0.006)\end{array}$ & $\begin{array}{c}-0.010^{* *} \\
(0.003)\end{array}$ \\
\hline $\operatorname{Age}^{2} / 100$ & $\begin{array}{c}0.020^{* * *} \\
(0.004)\end{array}$ & $\begin{array}{c}0.028^{* * *} \\
(0.006)\end{array}$ & $\begin{array}{c}0.031^{* * *} \\
(0.004)\end{array}$ \\
\hline Experience full time (years) & $\begin{array}{l}-0.001 \\
(0.001)\end{array}$ & $\begin{array}{c}-0.012^{* * * *} \\
(0.003)\end{array}$ & $\begin{array}{c}-0.005^{* * * *} \\
(0.001)\end{array}$ \\
\hline Experience part time (years) & $\begin{array}{c}-0.006^{* * *} \\
(0.001)\end{array}$ & $\begin{array}{c}-0.036^{* * *} \\
(0.006)\end{array}$ & $\begin{array}{c}-0.013^{* * *} \\
(0.002)\end{array}$ \\
\hline Experience unemployment (years) & $\begin{array}{c}-0.005^{+} \\
(0.003)\end{array}$ & $\begin{array}{c}-0.037^{* * *} \\
(0.005)\end{array}$ & $\begin{array}{c}-0.019^{* * *} \\
(0.003)\end{array}$ \\
\hline Public employer (0/1) & $\begin{array}{l}-0.030^{*} \\
(0.014)\end{array}$ & $\begin{array}{c}-0.378^{* * *} \\
(0.022)\end{array}$ & $\begin{array}{c}-0.209^{* * *} \\
(0.013)\end{array}$ \\
\hline Tenure (years) & $\begin{array}{c}0.007^{* * *} * \\
(0.001)\end{array}$ & $\begin{array}{c}0.006^{* * *} \\
(0.001)\end{array}$ & $\begin{array}{c}0.006^{* * *} \\
(0.001)\end{array}$ \\
\hline Firm size 10-99 & $\begin{array}{c}0.012 \\
(0.014)\end{array}$ & $\begin{array}{c}0.007 \\
(0.023)\end{array}$ & $\begin{array}{c}0.014 \\
(0.013)\end{array}$ \\
\hline Firm size 100-199 & $\begin{array}{l}-0.024 \\
(0.020)\end{array}$ & $\begin{array}{c}0.034 \\
(0.033)\end{array}$ & $\begin{array}{c}0.022 \\
(0.019)\end{array}$ \\
\hline Firm size 200-1999 & $\begin{array}{c}-0.040^{*} \\
(0.017)\end{array}$ & $\begin{array}{c}0.118^{* * *} \\
(0.027)\end{array}$ & $\begin{array}{c}0.064^{* * *} \\
(0.016)\end{array}$ \\
\hline Firm size $2000+$ & $\begin{array}{c}0.097^{* * *} \\
(0.021)\end{array}$ & $\begin{array}{c}0.250^{* * *} * \\
(0.029)\end{array}$ & $\begin{array}{c}0.191^{* * *} \\
(0.018)\end{array}$ \\
\hline Child under $16(0 / 1)$ & $\begin{array}{c}0.075^{* * *} \\
(0.013)\end{array}$ & $\begin{array}{c}0.174^{* * * *} \\
(0.017)\end{array}$ & $\begin{array}{c}0.140^{* * * *} \\
(0.011)\end{array}$ \\
\hline Indirect migration background & $\begin{array}{c}0.013 \\
(0.026)\end{array}$ & $\begin{array}{l}-0.032 \\
(0.038)\end{array}$ & $\begin{array}{l}-0.006 \\
(0.024)\end{array}$ \\
\hline Direct migration background & $\begin{array}{c}-0.096^{* * *} \\
(0.018)\end{array}$ & $\begin{array}{c}-0.193^{* * *} \\
(0.025)\end{array}$ & $\begin{array}{c}-0.160^{* * * *} \\
(0.016)\end{array}$ \\
\hline Full time employment $(0 / 1)$ & $\begin{array}{c}0.032^{* *} \\
(0.012)\end{array}$ & $\begin{array}{c}0.064^{* *} \\
(0.023)\end{array}$ & $\begin{array}{c}0.060^{* * *} \\
(0.011)\end{array}$ \\
\hline CASMIN General elementary (1b) & $\begin{array}{c}-0.084^{* * *} \\
(0.019)\end{array}$ & $\begin{array}{c}-0.134^{* * *} \\
(0.032)\end{array}$ & $\begin{array}{c}-0.107^{* * *} \\
(0.021)\end{array}$ \\
\hline CASMIN Basic vocational (1c) & $\begin{array}{c}-0.102 * * * \\
(0.021)\end{array}$ & $\begin{array}{c}-0.211^{* * *} \\
(0.032)\end{array}$ & $\begin{array}{c}-0.168^{* * *} \\
(0.021)\end{array}$ \\
\hline CASMIN Intermediate general (2b) & $\begin{array}{c}-0.043^{+} \\
(0.022)\end{array}$ & $\begin{array}{c}0.023 \\
(0.039)\end{array}$ & $\begin{array}{c}0.011 \\
(0.024)\end{array}$ \\
\hline CASMIN Intermediate vocational (2a) & $\begin{array}{l}-0.035 \\
(0.022)\end{array}$ & $\begin{array}{c}0.010 \\
(0.036)\end{array}$ & $\begin{array}{c}0.014 \\
(0.022)\end{array}$ \\
\hline CASMIN General maturity (2c_gen) & $\begin{array}{c}0.044 \\
(0.035)\end{array}$ & $\begin{array}{l}0.114^{*} \\
(0.052)\end{array}$ & $\begin{array}{c}0.104^{* *} \\
(0.033)\end{array}$ \\
\hline CASMIN Vocational maturity (2c_voc) & $\begin{array}{c}0.003 \\
(0.027)\end{array}$ & $\begin{array}{c}0.159^{* *} \\
(0.049)\end{array}$ & $\begin{array}{c}0.104^{* * *} \\
(0.029)\end{array}$ \\
\hline CASMIN Lower tertiarty (3a) & $\begin{array}{c}0.094^{* *} \\
(0.034)\end{array}$ & $\begin{array}{c}0.578^{* * *} \\
(0.055)\end{array}$ & $\begin{array}{c}0.414^{* * *} \\
(0.035)\end{array}$ \\
\hline CASMIN Higher tertiary (3b) & $\begin{array}{c}0.522^{* * *} \\
(0.035)\end{array}$ & $\begin{array}{c}0.954^{* * *} \\
(0.049)\end{array}$ & $\begin{array}{c}0.791^{* * *} \\
(0.030)\end{array}$ \\
\hline Constant & $\begin{array}{c}3.001^{* * * *} \\
(0.067)\end{array}$ & $\begin{array}{c}2.454^{* * * *} \\
(0.106)\end{array}$ & $\begin{array}{c}2.875^{* * *} * \\
(0.063)\end{array}$ \\
\hline$R^{2}$ & 0.142 & 0.268 & 0.225 \\
\hline
\end{tabular}


Table A9: Regression results for decomposition at the mean, controlling for occupations and industries (corresponding to Tab 4, columns 5 to 8).

\begin{tabular}{|c|c|c|c|}
\hline & Females $(\mathrm{N}=72,181)$ & Males $(\mathrm{N}=80,596)$ & Pooled ( $N=152,777)$ \\
\hline Female & & & $\begin{array}{c}-0.109^{* * *} \\
(0.007)\end{array}$ \\
\hline Extraversion & $\begin{array}{l}-0.002 \\
(0.003)\end{array}$ & $\begin{array}{l}-0.001 \\
(0.003)\end{array}$ & $\begin{array}{l}-0.002 \\
(0.002)\end{array}$ \\
\hline Agreeableness & $\begin{array}{c}-0.010^{* *} \\
(0.004)\end{array}$ & $\begin{array}{c}-0.025^{* * *} \\
(0.003)\end{array}$ & $\begin{array}{c}-0.017^{* * *} \\
(0.003)\end{array}$ \\
\hline Conscientiousness & $\begin{array}{c}0.001 \\
(0.004)\end{array}$ & $\begin{array}{c}-0.004 \\
(0.003)\end{array}$ & $\begin{array}{c}0.000 \\
(0.003)\end{array}$ \\
\hline Neuroticism & $\begin{array}{l}-0.004 \\
(0.003)\end{array}$ & $\begin{array}{c}-0.013^{* * *} \\
(0.003)\end{array}$ & $\begin{array}{c}-0.007^{* *} \\
(0.002)\end{array}$ \\
\hline Openness & $\begin{array}{l}-0.001 \\
(0.004)\end{array}$ & $\begin{array}{c}0.009^{* *} \\
(0.003)\end{array}$ & $\begin{array}{c}0.003 \\
(0.003)\end{array}$ \\
\hline External locus of control & $\begin{array}{c}-0.026^{* * *} \\
(0.004)\end{array}$ & $\begin{array}{c}-0.040^{* * *} \\
(0.004)\end{array}$ & $\begin{array}{c}-0.035^{* * *} \\
(0.003)\end{array}$ \\
\hline Positive reciprocity & $\begin{array}{c}0.003 \\
(0.003)\end{array}$ & $\begin{array}{c}0.013^{* * *} \\
(0.003)\end{array}$ & $\begin{array}{c}0.008^{* *} \\
(0.002)\end{array}$ \\
\hline Negative reciprocity & $\begin{array}{l}-0.004 \\
(0.004)\end{array}$ & $\begin{array}{c}0.000 \\
(0.003)\end{array}$ & $\begin{array}{l}-0.001 \\
(0.003)\end{array}$ \\
\hline Risk taking & $\begin{array}{c}0.002 \\
(0.003)\end{array}$ & $\begin{array}{c}0.011^{* * * *} \\
(0.003)\end{array}$ & $\begin{array}{c}0.007^{* * * *} \\
(0.002)\end{array}$ \\
\hline East Germany $(0 / 1)$ & $\begin{array}{c}-0.294^{* * *} \\
(0.009)\end{array}$ & $\begin{array}{c}-0.356^{* * *} \\
(0.009)\end{array}$ & $\begin{array}{c}-0.329^{* * *} \\
(0.007)\end{array}$ \\
\hline Married (0/1) & $\begin{array}{c}0.004 \\
(0.007)\end{array}$ & $\begin{array}{c}0.055^{* * * *} \\
(0.007)\end{array}$ & $\begin{array}{c}0.040^{* * *} \\
(0.005)\end{array}$ \\
\hline Age & $\begin{array}{c}0.063^{* * *} \\
(0.002)\end{array}$ & $\begin{array}{c}0.053^{* * *} \\
(0.002)\end{array}$ & $\begin{array}{c}0.062^{* * *} \\
(0.002)\end{array}$ \\
\hline $\operatorname{Age}^{2} / 100$ & $\begin{array}{c}-0.070^{* * *} \\
(0.002)\end{array}$ & $\begin{array}{c}-0.052^{* * *} \\
(0.003)\end{array}$ & $\begin{array}{c}-0.067^{* * *} \\
(0.002)\end{array}$ \\
\hline Experience full time (years) & $\begin{array}{c}0.004^{* * *} \\
(0.001)\end{array}$ & $\begin{array}{l}-0.001 \\
(0.001)\end{array}$ & $\begin{array}{c}0.003^{* * *} \\
(0.001)\end{array}$ \\
\hline Experience part time (years) & $\begin{array}{c}0.005^{* * *} \\
(0.001)\end{array}$ & $\begin{array}{c}0.007^{* *} \\
(0.002)\end{array}$ & $\begin{array}{c}0.006^{* * *} * \\
(0.001)\end{array}$ \\
\hline Experience unemployment (years) & $\begin{array}{c}-0.030^{* * *} \\
(0.003)\end{array}$ & $\begin{array}{c}-0.037^{* * *} \\
(0.003)\end{array}$ & $\begin{array}{c}-0.033^{* * *} \\
(0.002)\end{array}$ \\
\hline Public employer (0/1) & $\begin{array}{c}0.027^{* *} \\
(0.008)\end{array}$ & $\begin{array}{c}-0.049^{* * *} \\
(0.010)\end{array}$ & $\begin{array}{l}-0.005 \\
(0.007)\end{array}$ \\
\hline Tenure (years) & $\begin{array}{c}0.007^{* * * *} \\
(0.000)\end{array}$ & $\begin{array}{c}0.005^{* * * *} \\
(0.000)\end{array}$ & $\begin{array}{c}0.006^{* * * *} \\
(0.000)\end{array}$ \\
\hline Firm size $10-99$ & $\begin{array}{c}0.134^{* * *} \\
(0.010)\end{array}$ & $\begin{array}{c}0.113^{* * *} \\
(0.011)\end{array}$ & $\begin{array}{c}0.126^{* * *} \\
(0.008)\end{array}$ \\
\hline Firm size 100-199 & $\begin{array}{c}0.188^{* * *} \\
(0.013)\end{array}$ & $\begin{array}{c}0.158^{* * *} \\
(0.015)\end{array}$ & $\begin{array}{c}0.176^{* * *} \\
(0.010)\end{array}$ \\
\hline Firm size 200-1999 & $\begin{array}{c}0.220^{* * * *} \\
(0.012)\end{array}$ & $\begin{array}{c}0.209^{* * * *} \\
(0.013)\end{array}$ & $\begin{array}{c}0.217^{* * *} \\
(0.009)\end{array}$ \\
\hline Firm size $2000+$ & $\begin{array}{c}0.280^{* * * *} \\
(0.012)\end{array}$ & $\begin{array}{c}0.269^{* * * *} \\
(0.013)\end{array}$ & $\begin{array}{c}0.277^{* * * *} \\
(0.009)\end{array}$ \\
\hline Child under $16(0 / 1)$ & $\begin{array}{c}0.026^{* * * *} \\
(0.006)\end{array}$ & $\begin{array}{c}0.036^{* * * *} \\
(0.006)\end{array}$ & $\begin{array}{c}0.044^{* * * *} \\
(0.004)\end{array}$ \\
\hline Indirect migration background & $\begin{array}{c}0.015 \\
(0.017)\end{array}$ & $\begin{array}{c}0.017 \\
(0.016)\end{array}$ & $\begin{array}{c}0.018 \\
(0.012)\end{array}$ \\
\hline Direct migration background & $\begin{array}{c}-0.028^{*} \\
(0.011)\end{array}$ & $\begin{array}{c}-0.031^{* *} \\
(0.010)\end{array}$ & $\begin{array}{c}-0.024^{* *} \\
(0.008)\end{array}$ \\
\hline Full time employment $(0 / 1)$ & $\begin{array}{c}0.167^{* * *} \\
(0.007)\end{array}$ & $\begin{array}{c}0.568^{* * * *} \\
(0.017)\end{array}$ & $\begin{array}{c}0.276^{* * * *} \\
(0.007)\end{array}$ \\
\hline CASMIN General elementary (1b) & $\begin{array}{c}0.022 \\
(0.033)\end{array}$ & $\begin{array}{c}0.027 \\
(0.037)\end{array}$ & $\begin{array}{c}0.028 \\
(0.028)\end{array}$ \\
\hline CASMIN Basic vocational (1c) & $\begin{array}{l}0.085^{*} \\
(0.033)\end{array}$ & $\begin{array}{r}0.106^{* *} \\
(0.036)\end{array}$ & $\begin{array}{c}0.121^{* * *} \\
(0.028)\end{array}$ \\
\hline CASMIN Intermediate general (2b) & $\begin{array}{l}-0.049 \\
(0.037)\end{array}$ & $\begin{array}{c}0.012 \\
(0.040)\end{array}$ & $\begin{array}{l}-0.021 \\
(0.030)\end{array}$ \\
\hline CASMIN Intermediate vocational (2a) & $\begin{array}{c}0.171^{* * *} \\
(0.034)\end{array}$ & $\begin{array}{c}0.166^{* * *} \\
(0.036)\end{array}$ & $\begin{array}{c}0.194^{* * *} \\
(0.028)\end{array}$ \\
\hline CASMIN General maturity (2c_gen) & $\begin{array}{c}-0.137^{* * *} \\
(0.040)\end{array}$ & $\begin{array}{c}0.021 \\
(0.044)\end{array}$ & $\begin{array}{c}-0.061^{+} \\
(0.033)\end{array}$ \\
\hline CASMIN Vocational maturity (2c_voc) & $\begin{array}{c}0.219^{* * *} \\
(0.035)\end{array}$ & $\begin{array}{c}0.219^{* * *} \\
(0.038)\end{array}$ & $\begin{array}{c}0.245^{* * *} \\
(0.029)\end{array}$ \\
\hline CASMIN Lower tertiarty (3a) & $\begin{array}{c}0.253^{* * *} \\
(0.036)\end{array}$ & $\begin{array}{c}0.313^{* * *} \\
(0.039)\end{array}$ & $\begin{array}{c}0.313^{* * *} \\
(0.029)\end{array}$ \\
\hline CASMIN Higher tertiary (3b) & $\begin{array}{c}0.318^{* * *} \\
(0.035)\end{array}$ & $\begin{array}{c}0.387^{* * * *} \\
(0.038)\end{array}$ & $\begin{array}{c}0.382^{* * *} \\
(0.029)\end{array}$ \\
\hline Constant & $\begin{array}{l}0.310^{*} \\
(0.121)\end{array}$ & $\begin{array}{c}0.106 \\
(0.092)\end{array}$ & $\begin{array}{c}0.204^{* *} \\
(0.078)\end{array}$ \\
\hline$R^{2}$ & 0.542 & 0.616 & 0.588 \\
\hline
\end{tabular}

Notes: Omitted: survey year dummies, firm size $<10$ (reference category), ISCO-2-digit dummies, NACE top category dummies. Significance levels: ${ }^{+} p<0.1,{ }^{*} p<0.05,{ }^{* *} p<0.01,{ }^{* * *} p<0.001$. Source: SOEP v32 1991-2015, own calculations. 
Table A10: Regression results for decomposition at the 10th percentile, controlling for occupations and industries (corresponding to Tab 4, columns 5 to 8).

\begin{tabular}{|c|c|c|c|}
\hline & Females $(\mathrm{N}=72,181)$ & Males $(\mathrm{N}=80,596)$ & Pooled ( $N=152,777)$ \\
\hline Female & & & $\begin{array}{l}-0.009 \\
(0.015)\end{array}$ \\
\hline Extraversion & $\begin{array}{l}-0.009 \\
(0.010)\end{array}$ & $\begin{array}{l}-0.008 \\
(0.006)\end{array}$ & $\begin{array}{l}-0.006 \\
(0.006)\end{array}$ \\
\hline Agreeableness & $\begin{array}{c}0.016 \\
(0.010)\end{array}$ & $\begin{array}{c}-0.020^{* * *} \\
(0.006)\end{array}$ & $\begin{array}{l}-0.005 \\
(0.006)\end{array}$ \\
\hline Conscientiousness & $\begin{array}{l}-0.003 \\
(0.010)\end{array}$ & $\begin{array}{l}-0.001 \\
(0.006)\end{array}$ & $\begin{array}{c}0.002 \\
(0.006)\end{array}$ \\
\hline Neuroticism & $\begin{array}{c}0.004 \\
(0.009)\end{array}$ & $\begin{array}{l}-0.014^{*} \\
(0.006)\end{array}$ & $\begin{array}{l}-0.003 \\
(0.006)\end{array}$ \\
\hline Openness & $\begin{array}{l}-0.012 \\
(0.010)\end{array}$ & $\begin{array}{c}0.010 \\
(0.006)\end{array}$ & $\begin{array}{l}-0.003 \\
(0.006)\end{array}$ \\
\hline External locus of control & $\begin{array}{c}-0.042^{* * *} \\
(0.011)\end{array}$ & $\begin{array}{c}-0.029^{* * *} \\
(0.007)\end{array}$ & $\begin{array}{c}-0.040^{* * *} \\
(0.006)\end{array}$ \\
\hline Positive reciprocity & $\begin{array}{l}-0.001 \\
(0.010)\end{array}$ & $\begin{array}{c}0.021^{* *} \\
(0.007)\end{array}$ & $\begin{array}{c}0.009 \\
(0.006)\end{array}$ \\
\hline Negative reciprocity & $\begin{array}{c}0.000 \\
(0.011)\end{array}$ & $\begin{array}{l}-0.007 \\
(0.006)\end{array}$ & $\begin{array}{l}-0.003 \\
(0.006)\end{array}$ \\
\hline Risk taking & $\begin{array}{l}-0.013 \\
(0.009)\end{array}$ & $\begin{array}{l}-0.008 \\
(0.005)\end{array}$ & $\begin{array}{l}-0.012^{*} \\
(0.005)\end{array}$ \\
\hline East Germany (0/1) & $\begin{array}{c}-0.500^{* * *} * \\
(0.026)\end{array}$ & $\begin{array}{c}-0.330^{* * *} \\
(0.019)\end{array}$ & $\begin{array}{c}-0.422^{* * *} * \\
(0.016)\end{array}$ \\
\hline Married (0/1) & $\begin{array}{c}0.014 \\
(0.019)\end{array}$ & $\begin{array}{l}0.031^{*} \\
(0.013)\end{array}$ & $\begin{array}{c}0.033^{* *} \\
(0.012)\end{array}$ \\
\hline Age & $\begin{array}{c}0.163^{* * * *} \\
(0.007)\end{array}$ & $\begin{array}{c}0.112^{* * *} \\
(0.005)\end{array}$ & $\begin{array}{c}0.159^{* * *} * \\
(0.004)\end{array}$ \\
\hline $\mathrm{Age}^{2} / 100$ & $\begin{array}{c}-0.187^{* * *} \\
(0.008)\end{array}$ & $\begin{array}{c}-0.120^{* * *} \\
(0.005)\end{array}$ & $\begin{array}{c}-0.178^{* * *} \\
(0.005)\end{array}$ \\
\hline Experience full time (years) & $\begin{array}{l}0.005^{*} \\
(0.002)\end{array}$ & $\begin{array}{l}-0.002 \\
(0.002)\end{array}$ & $\begin{array}{c}0.002 \\
(0.002)\end{array}$ \\
\hline Experience part time (years) & $\begin{array}{c}0.021^{* * * *} \\
(0.003)\end{array}$ & $\begin{array}{c}0.055^{* * * *} \\
(0.005)\end{array}$ & $\begin{array}{c}0.029^{* * * *} \\
(0.002)\end{array}$ \\
\hline Experience unemployment (years) & $\begin{array}{c}-0.067^{* * *} \\
(0.009)\end{array}$ & $\begin{array}{c}-0.025^{* * *} \\
(0.007)\end{array}$ & $\begin{array}{c}-0.055^{* * *} \\
(0.006)\end{array}$ \\
\hline Public employer $(0 / 1)$ & $\begin{array}{c}0.031 \\
(0.022)\end{array}$ & $\begin{array}{c}0.025 \\
(0.018)\end{array}$ & $\begin{array}{c}0.039^{* *} \\
(0.015)\end{array}$ \\
\hline Tenure (years) & $\begin{array}{c}0.005^{* * *} \\
(0.001)\end{array}$ & $\begin{array}{c}0.002^{* * *} * \\
(0.001)\end{array}$ & $\begin{array}{c}0.003^{* * *} \\
(0.001)\end{array}$ \\
\hline Firm size 10-99 & $\begin{array}{c}0.357^{* * *} \\
(0.034)\end{array}$ & $\begin{array}{c}0.240^{* * *} \\
(0.026)\end{array}$ & $\begin{array}{c}0.313^{* * *} \\
(0.022)\end{array}$ \\
\hline Firm size $100-199$ & $0.462^{* * *}$ & $0.259^{* * *}$ & $\begin{array}{c}0.373^{* * *} \\
(0.026)\end{array}$ \\
\hline Firm size 200-1999 & $\begin{array}{c}0.536^{* * *} * \\
(0.035)\end{array}$ & $\begin{array}{c}0.300^{* * *} * \\
(0.027)\end{array}$ & $\begin{array}{c}0.422^{* * * *} \\
(0.023)\end{array}$ \\
\hline Firm size $2000+$ & $\begin{array}{c}0.559^{* * *} \\
(0.036)\end{array}$ & $\begin{array}{c}0.315^{* * *} * \\
(0.027)\end{array}$ & $\begin{array}{c}0.443 * * * \\
(0.023)\end{array}$ \\
\hline Child under $16(0 / 1)$ & $\begin{array}{l}-0.010 \\
(0.019)\end{array}$ & $\begin{array}{c}-0.057^{* * *} \\
(0.012)\end{array}$ & $\begin{array}{c}-0.019^{+} \\
(0.011)\end{array}$ \\
\hline Indirect migration background & $\begin{array}{l}0.086^{+} \\
(0.045)\end{array}$ & 0.019 & $\begin{array}{l}0.052^{+} \\
(0.028)\end{array}$ \\
\hline Direct migration background & $\begin{array}{c}0.105^{* *} \\
(0.034)\end{array}$ & $\begin{array}{r}0.054^{* *} \\
(0.018)\end{array}$ & $\begin{array}{c}0.099^{* * *} \\
(0.020)\end{array}$ \\
\hline Full time employment $(0 / 1)$ & $\begin{array}{c}0.621^{* * *} \\
(0.023)\end{array}$ & $\begin{array}{c}1.857^{* * * *} \\
(0.047)\end{array}$ & $\begin{array}{c}0.916^{* * *} \\
(0.021)\end{array}$ \\
\hline CASMIN General elementary (1b) & $\begin{array}{c}0.059 \\
(0.104)\end{array}$ & $\begin{array}{c}0.083 \\
(0.074)\end{array}$ & $\begin{array}{c}0.073 \\
(0.069)\end{array}$ \\
\hline CASMIN Basic vocational (1c) & $\begin{array}{l}0.187^{+} \\
(0.103)\end{array}$ & $\begin{array}{c}0.271^{* * *} \\
(0.070)\end{array}$ & $\begin{array}{c}0.290^{* * *} \\
(0.066)\end{array}$ \\
\hline CASMIN Intermediate general (2b) & $\begin{array}{c}-0.455^{* * *} \\
(0.116)\end{array}$ & $\begin{array}{c}-0.227^{* *} \\
(0.088)\end{array}$ & $\begin{array}{c}-0.366^{* * *} \\
(0.077)\end{array}$ \\
\hline CASMIN Intermediate vocational (2a) & $\begin{array}{c}0.282^{* *} \\
(0.103)\end{array}$ & $\begin{array}{c}0.290^{* * *} \\
(0.072)\end{array}$ & $\begin{array}{c}0.355^{* * *} \\
(0.066)\end{array}$ \\
\hline CASMIN General maturity (2c_gen) & $\begin{array}{c}-0.804^{* * *} \\
(0.126)\end{array}$ & $\begin{array}{l}-0.222^{*} \\
(0.094)\end{array}$ & $\begin{array}{c}-0.546^{* * *} * \\
(0.082)\end{array}$ \\
\hline CASMIN Vocational maturity (2c_voc) & $\begin{array}{c}0.341^{* *} \\
(0.105)\end{array}$ & $\begin{array}{c}0.319^{* * *} * \\
(0.073)\end{array}$ & $\begin{array}{c}0.398^{* * *} * \\
(0.068)\end{array}$ \\
\hline CASMIN Lower tertiarty (3a) & $\begin{array}{c}0.370^{* * * *} \\
(0.106)\end{array}$ & $\begin{array}{c}0.302^{* * * *} \\
(0.074)\end{array}$ & $\begin{array}{c}0.379^{* * * *} \\
(0.068)\end{array}$ \\
\hline CASMIN Higher tertiary (3b) & $\begin{array}{c}0.291^{* *} \\
(0.105)\end{array}$ & $\begin{array}{c}0.295^{* * * *} \\
(0.074)\end{array}$ & $\begin{array}{c}0.347^{* * * *} \\
(0.068)\end{array}$ \\
\hline Constant & $\begin{array}{c}-4.187^{* * *} \\
(0.252)\end{array}$ & $\begin{array}{c}-3.898^{* * *} \\
(0.171)\end{array}$ & $\begin{array}{c}-4.253^{* * *} \\
(0.153)\end{array}$ \\
\hline$R^{2}$ & 0.267 & 0.383 & 0.293 \\
\hline
\end{tabular}

Notes: Omitted: survey year dummies, firm size $<10$ (reference category), ISCO-2-digit dummies, NACE top category dummies. Significance levels: ${ }^{+} p<0.1,{ }^{*} p<0.05,{ }^{* *} p<0.01,{ }^{* * *} p<0.001$. Source: SOEP v32 1991-2015, own calculations. 
Table A11: Regression results for decomposition at the 50th percentile, controlling for occupations and industries (corresponding to Tab 4, columns 5 to 8).

\begin{tabular}{|c|c|c|c|}
\hline & Females $(\mathrm{N}=72,181)$ & Males $(\mathrm{N}=80,596)$ & Pooled (N=152,777) \\
\hline Female & & & $\begin{array}{c}-0.126^{* * *} \\
(0.007)\end{array}$ \\
\hline Extraversion & $\begin{array}{l}-0.004 \\
(0.004)\end{array}$ & $\begin{array}{l}-0.001 \\
(0.004)\end{array}$ & $\begin{array}{l}-0.002 \\
(0.003)\end{array}$ \\
\hline Agreeableness & $\begin{array}{c}-0.014^{* * *} \\
(0.004)\end{array}$ & $\begin{array}{c}-0.021^{* * *} \\
(0.004)\end{array}$ & $\begin{array}{c}-0.017^{* * *} * \\
(0.003)\end{array}$ \\
\hline Conscientiousness & $\begin{array}{c}0.001 \\
(0.004)\end{array}$ & $\begin{array}{l}-0.008^{*} \\
(0.004)\end{array}$ & $\begin{array}{l}-0.003 \\
(0.003)\end{array}$ \\
\hline Neuroticism & $\begin{array}{l}-0.005 \\
(0.004)\end{array}$ & $\begin{array}{l}-0.009^{*} \\
(0.004)\end{array}$ & $\begin{array}{l}-0.006^{*} \\
(0.003)\end{array}$ \\
\hline Openness & $\begin{array}{c}0.002 \\
(0.004)\end{array}$ & $\begin{array}{c}0.006 \\
(0.004)\end{array}$ & $\begin{array}{c}0.003 \\
(0.003)\end{array}$ \\
\hline External locus of control & $\begin{array}{c}-0.015^{* * *} \\
(0.004)\end{array}$ & $\begin{array}{c}-0.025^{* * *} \\
(0.004)\end{array}$ & $\begin{array}{c}-0.021^{* * *} \\
(0.003)\end{array}$ \\
\hline Positive reciprocity & $\begin{array}{c}0.006 \\
(0.004)\end{array}$ & $\begin{array}{c}0.007 \\
(0.004)\end{array}$ & $\begin{array}{l}0.006^{*} \\
(0.003)\end{array}$ \\
\hline Negative reciprocity & $\begin{array}{l}-0.005 \\
(0.004)\end{array}$ & $\begin{array}{c}0.001 \\
(0.004)\end{array}$ & $\begin{array}{l}-0.002 \\
(0.003)\end{array}$ \\
\hline Risk taking & $\begin{array}{c}0.005 \\
(0.003)\end{array}$ & $\begin{array}{c}0.012^{* * * *} \\
(0.003)\end{array}$ & $\begin{array}{c}0.010^{* * *} \\
(0.002)\end{array}$ \\
\hline East Germany (0/1) & $\begin{array}{c}-0.244^{* * *} * \\
(0.010)\end{array}$ & $\begin{array}{c}-0.348^{* * *} \\
(0.010)\end{array}$ & $\begin{array}{c}-0.298^{* * *} * \\
(0.007)\end{array}$ \\
\hline Married (0/1) & $\begin{array}{c}-0.020^{*} \\
(0.008)\end{array}$ & $\begin{array}{c}0.049^{* * *} * \\
(0.009)\end{array}$ & $\begin{array}{c}0.020^{* * *} \\
(0.006)\end{array}$ \\
\hline Age & $\begin{array}{c}0.043 * * * \\
(0.002)\end{array}$ & $\begin{array}{c}0.054^{* * *} * \\
(0.003)\end{array}$ & $\begin{array}{c}0.049^{* * *} * \\
(0.002)\end{array}$ \\
\hline $\operatorname{Age}^{2} / 100$ & $\begin{array}{c}-0.048^{* * *} \\
(0.003)\end{array}$ & $\begin{array}{c}-0.060^{* * *} \\
(0.003)\end{array}$ & $\begin{array}{c}-0.057^{* * *} \\
(0.002)\end{array}$ \\
\hline Experience full time (years) & $\begin{array}{c}0.004^{* * *} \\
(0.001)\end{array}$ & $\begin{array}{c}0.002 \\
(0.001)\end{array}$ & $\begin{array}{c}0.004^{* * * *} \\
(0.001)\end{array}$ \\
\hline Experience part time (years) & $\begin{array}{c}0.000 \\
(0.001)\end{array}$ & $\begin{array}{l}-0.002 \\
(0.002)\end{array}$ & $\begin{array}{c}0.001 \\
(0.001)\end{array}$ \\
\hline Experience unemployment (years) & $\begin{array}{c}-0.019^{* * *} \\
(0.002)\end{array}$ & $\begin{array}{c}-0.039^{* * *} \\
(0.003)\end{array}$ & $\begin{array}{c}-0.026^{* * *} \\
(0.002)\end{array}$ \\
\hline Public employer (0/1) & $\begin{array}{c}0.064^{* * *} * \\
(0.011)\end{array}$ & $\begin{array}{c}0.003 \\
(0.012)\end{array}$ & $\begin{array}{c}0.038^{* * *} * \\
(0.008)\end{array}$ \\
\hline Tenure (years) & $\begin{array}{c}0.010^{* * *} * \\
(0.001)\end{array}$ & $\begin{array}{c}0.007^{* * *} * \\
(0.000)\end{array}$ & $\begin{array}{c}0.008^{* * *} * \\
(0.000)\end{array}$ \\
\hline Firm size $10-99$ & $0.098^{* * *}$ & $0.101^{* * *}$ & $0.098^{* * *}$ \\
\hline Firm size $100-199$ & $\begin{array}{c}0.166^{* * *} \\
(0.014)\end{array}$ & $\begin{array}{c}0.168^{* * * *} \\
(0.015)\end{array}$ & $\begin{array}{c}0.167^{* * *} \\
(0.010)\end{array}$ \\
\hline Firm size 200-1999 & $\begin{array}{c}0.193^{* * *} \\
(0.012)\end{array}$ & $\begin{array}{c}0.223^{* * * *} \\
(0.013)\end{array}$ & $\begin{array}{c}0.209^{* * *} \\
(0.009)\end{array}$ \\
\hline Firm size $2000+$ & $\begin{array}{c}0.237^{* * * *} \\
(0.012)\end{array}$ & $\begin{array}{c}0.262^{* * * *} \\
(0.013)\end{array}$ & $\begin{array}{c}0.250^{* * * *} \\
(0.009)\end{array}$ \\
\hline Child under $16(0 / 1)$ & $\begin{array}{l}0.018^{*} \\
(0.007)\end{array}$ & $\begin{array}{c}0.029^{* * *} * \\
(0.007)\end{array}$ & $\begin{array}{c}0.035^{* * *} \\
(0.005)\end{array}$ \\
\hline Indirect migration background & $\begin{array}{l}-0.006 \\
(0.019)\end{array}$ & $\begin{array}{c}0.022 \\
(0.017)\end{array}$ & $\begin{array}{c}0.009 \\
(0.013)\end{array}$ \\
\hline Direct migration background & $\begin{array}{c}-0.076^{* * *} \\
(0.012)\end{array}$ & $\begin{array}{c}-0.060^{* * *} \\
(0.013)\end{array}$ & $\begin{array}{c}-0.065^{* * *} \\
(0.009)\end{array}$ \\
\hline Full time employment $(0 / 1)$ & $\begin{array}{c}0.029^{* * *} \\
(0.008)\end{array}$ & $\begin{array}{c}0.171^{* * *} \\
(0.011)\end{array}$ & $\begin{array}{c}0.085^{* * *} \\
(0.007)\end{array}$ \\
\hline CASMIN General elementary (1b) & $\begin{array}{l}-0.015 \\
(0.026)\end{array}$ & $\begin{array}{l}-0.006 \\
(0.033)\end{array}$ & $\begin{array}{l}-0.010 \\
(0.022)\end{array}$ \\
\hline CASMIN Basic vocational (1c) & $\begin{array}{c}0.014 \\
(0.026)\end{array}$ & $\begin{array}{l}0.059^{+} \\
(0.032)\end{array}$ & $\begin{array}{c}0.061^{* *} \\
(0.022)\end{array}$ \\
\hline CASMIN Intermediate general (2b) & $\begin{array}{c}0.055^{+} \\
(0.028)\end{array}$ & $\begin{array}{c}0.031 \\
(0.035)\end{array}$ & $\begin{array}{l}0.046^{+} \\
(0.024)\end{array}$ \\
\hline CASMIN Intermediate vocational (2a) & $\begin{array}{c}0.112^{* * *} \\
(0.026)\end{array}$ & $\begin{array}{l}0.073^{*} \\
(0.033)\end{array}$ & $\begin{array}{c}0.106^{* * *} \\
(0.022)\end{array}$ \\
\hline CASMIN General maturity (2c_gen) & $\begin{array}{l}-0.037 \\
(0.030)\end{array}$ & $\begin{array}{l}-0.044 \\
(0.038)\end{array}$ & $\begin{array}{l}-0.029 \\
(0.025)\end{array}$ \\
\hline CASMIN Vocational maturity (2c_voc) & $\begin{array}{c}0.170^{* * *} \\
(0.028)\end{array}$ & $\begin{array}{c}0.135^{* * *} * \\
(0.035)\end{array}$ & $\begin{array}{c}0.169^{* * *} \\
(0.023)\end{array}$ \\
\hline CASMIN Lower tertiarty (3a) & $\begin{array}{c}0.234^{* * *} \\
(0.031)\end{array}$ & $\begin{array}{c}0.190^{* * *} \\
(0.035)\end{array}$ & $\begin{array}{c}0.235^{* * *} \\
(0.024)\end{array}$ \\
\hline CASMIN Higher tertiary (3b) & $\begin{array}{c}0.255^{* * *} \\
(0.028)\end{array}$ & $\begin{array}{c}0.227^{* * *} * \\
(0.035)\end{array}$ & $\begin{array}{c}0.263^{* * *} \\
(0.023)\end{array}$ \\
\hline Constant & $\begin{array}{c}1.159^{* * *} \\
(0.138)\end{array}$ & $\begin{array}{c}0.618^{* * *} \\
(0.084)\end{array}$ & $\begin{array}{c}0.876^{* * *} \\
(0.076)\end{array}$ \\
\hline$R^{2}$ & 0.428 & 0.453 & 0.454 \\
\hline
\end{tabular}

Notes: Omitted: survey year dummies, firm size $<10$ (reference category), ISCO-2-digit dummies, NACE top category dummies. Significance levels: ${ }^{+} p<0.1,{ }^{*} p<0.05,{ }^{* *} p<0.01,{ }^{* * *} p<0.001$. Source: SOEP v32 1991-2015, own calculations. 
Table A12: Regression results for decomposition at the 90th percentile, controlling for occupations and industries (corresponding to Tab 4, columns 5 to 8).

\begin{tabular}{|c|c|c|c|}
\hline & Females $(\mathrm{N}=72,181)$ & Males $(\mathrm{N}=80,596)$ & Pooled ( $N=152,777)$ \\
\hline Female & & & $\begin{array}{c}-0.178^{* * *} \\
(0.014)\end{array}$ \\
\hline Extraversion & $\begin{array}{l}-0.001 \\
(0.006)\end{array}$ & $\begin{array}{c}0.002 \\
(0.008)\end{array}$ & $\begin{array}{l}-0.004 \\
(0.005)\end{array}$ \\
\hline Agreeableness & $\begin{array}{c}-0.024^{* * *} \\
(0.006)\end{array}$ & $\begin{array}{c}-0.039^{* * *} \\
(0.008)\end{array}$ & $\begin{array}{c}-0.029^{* * *} \\
(0.005)\end{array}$ \\
\hline Conscientiousness & $\begin{array}{c}0.006 \\
(0.006)\end{array}$ & $\begin{array}{c}0.005 \\
(0.009)\end{array}$ & $\begin{array}{c}0.008 \\
(0.006)\end{array}$ \\
\hline Neuroticism & $\begin{array}{c}-0.011^{*} \\
(0.006)\end{array}$ & $\begin{array}{l}-0.021^{*} \\
(0.008)\end{array}$ & $\begin{array}{c}-0.014^{* *} \\
(0.005)\end{array}$ \\
\hline Openness & $\begin{array}{l}-0.004 \\
(0.006)\end{array}$ & $\begin{array}{c}0.010 \\
(0.009)\end{array}$ & $\begin{array}{c}0.003 \\
(0.005)\end{array}$ \\
\hline External locus of control & $\begin{array}{c}-0.027^{* * *} * \\
(0.005)\end{array}$ & $\begin{array}{c}-0.060^{* * *} \\
(0.008)\end{array}$ & $\begin{array}{c}-0.045^{* * *} \\
(0.005)\end{array}$ \\
\hline Positive reciprocity & $\begin{array}{c}0.007 \\
(0.006)\end{array}$ & $\begin{array}{l}0.022^{*} \\
(0.009)\end{array}$ & $\begin{array}{c}0.015^{* * *} \\
(0.005)\end{array}$ \\
\hline Negative reciprocity & $\begin{array}{c}0.004 \\
(0.005)\end{array}$ & $\begin{array}{l}-0.002 \\
(0.008)\end{array}$ & $\begin{array}{c}0.002 \\
(0.005)\end{array}$ \\
\hline Risk taking & $\begin{array}{l}0.009^{+} \\
(0.005)\end{array}$ & $\begin{array}{c}0.024 * * * \\
(0.007)\end{array}$ & $\begin{array}{c}0.019^{* * *} \\
(0.005)\end{array}$ \\
\hline East Germany $(0 / 1)$ & $\begin{array}{c}-0.142^{* * *} \\
(0.014)\end{array}$ & $\begin{array}{c}-0.344^{* * *} \\
(0.019)\end{array}$ & $\begin{array}{c}-0.251^{* * *} \\
(0.012)\end{array}$ \\
\hline Married (0/1) & $\begin{array}{c}0.008 \\
(0.013)\end{array}$ & $\begin{array}{c}0.063^{* * *} \\
(0.018)\end{array}$ & $\begin{array}{c}0.059^{* * *} \\
(0.011)\end{array}$ \\
\hline Age & $\begin{array}{c}-0.009^{* *} \\
(0.003)\end{array}$ & $\begin{array}{l}-0.006 \\
(0.005)\end{array}$ & $\begin{array}{c}-0.014^{* * *} \\
(0.003)\end{array}$ \\
\hline $\mathrm{Age}^{2} / 100$ & $\begin{array}{c}0.018^{* * *} \\
(0.004)\end{array}$ & $\begin{array}{c}0.031^{* * *} \\
(0.006)\end{array}$ & $\begin{array}{c}0.032^{* * * *} \\
(0.004)\end{array}$ \\
\hline Experience full time (years) & $\begin{array}{c}0.000 \\
(0.001)\end{array}$ & $\begin{array}{c}-0.007^{*} \\
(0.003)\end{array}$ & $\begin{array}{c}-0.002^{*} \\
(0.001)\end{array}$ \\
\hline Experience part time (years) & $\begin{array}{c}-0.004^{* * *} \\
(0.001)\end{array}$ & $\begin{array}{c}-0.032^{* * *} \\
(0.006)\end{array}$ & $\begin{array}{c}-0.010^{* * *} \\
(0.001)\end{array}$ \\
\hline Experience unemployment (years) & $\begin{array}{l}-0.001 \\
(0.002)\end{array}$ & $\begin{array}{c}-0.026^{* * *} \\
(0.005)\end{array}$ & $\begin{array}{c}-0.012^{* * *} \\
(0.002)\end{array}$ \\
\hline Public employer (0/1) & $\begin{array}{c}-0.043^{* *} \\
(0.014)\end{array}$ & $\begin{array}{c}-0.228^{* * *} \\
(0.027)\end{array}$ & $\begin{array}{c}-0.130^{* * *} \\
(0.015)\end{array}$ \\
\hline Tenure (years) & $\begin{array}{c}0.006^{* * *} \\
(0.001)\end{array}$ & $\begin{array}{c}0.005^{* * *} \\
(0.001)\end{array}$ & $\begin{array}{c}0.006^{* * *} \\
(0.001)\end{array}$ \\
\hline Firm size 10-99 & $\begin{array}{c}0.007 \\
(0.012)\end{array}$ & $\begin{array}{c}0.025 \\
(0.021)\end{array}$ & $\begin{array}{c}0.020 \\
(0.012)\end{array}$ \\
\hline Firm size 100-199 & $\begin{array}{l}-0.019 \\
(0.019)\end{array}$ & $\begin{array}{c}0.038 \\
(0.031)\end{array}$ & $\begin{array}{c}0.015 \\
(0.018)\end{array}$ \\
\hline Firm size 200-1999 & $\begin{array}{c}-0.029^{+} \\
(0.015)\end{array}$ & $\begin{array}{c}0.095^{* * *} \\
(0.026)\end{array}$ & $\begin{array}{c}0.040^{* *} \\
(0.016)\end{array}$ \\
\hline Firm size $2000+$ & $\begin{array}{c}0.082^{* * * *} \\
(0.019)\end{array}$ & $\begin{array}{c}0.242^{* * * *} \\
(0.028)\end{array}$ & $\begin{array}{c}0.167^{* * * *} \\
(0.017)\end{array}$ \\
\hline Child under $16(0 / 1)$ & $\begin{array}{c}0.071^{* * * *} \\
(0.012)\end{array}$ & $\begin{array}{c}0.164^{* * *} \\
(0.016)\end{array}$ & $\begin{array}{c}0.134^{* * *} \\
(0.010)\end{array}$ \\
\hline Indirect migration background & $\begin{array}{c}0.009 \\
(0.025)\end{array}$ & $\begin{array}{l}-0.014 \\
(0.035)\end{array}$ & $\begin{array}{c}0.002 \\
(0.023)\end{array}$ \\
\hline Direct migration background & $\begin{array}{c}-0.068^{* * *} \\
(0.016)\end{array}$ & $\begin{array}{c}-0.136^{* * *} \\
(0.022)\end{array}$ & $\begin{array}{c}-0.107^{* * *} \\
(0.014)\end{array}$ \\
\hline Full time employment $(0 / 1)$ & $\begin{array}{c}0.008 \\
(0.011)\end{array}$ & $\begin{array}{c}0.025 \\
(0.022)\end{array}$ & $\begin{array}{c}0.028^{* * *} \\
(0.010)\end{array}$ \\
\hline CASMIN General elementary (1b) & $\begin{array}{c}-0.076^{* * *} \\
(0.018)\end{array}$ & $\begin{array}{c}-0.109^{* * *} \\
(0.031)\end{array}$ & $\begin{array}{c}-0.088^{* * *} \\
(0.019)\end{array}$ \\
\hline CASMIN Basic vocational (1c) & $\begin{array}{c}-0.087^{* * *} \\
(0.019)\end{array}$ & $\begin{array}{c}-0.188^{* * *} \\
(0.031)\end{array}$ & $\begin{array}{c}-0.150^{* * *} \\
(0.020)\end{array}$ \\
\hline CASMIN Intermediate general (2b) & $\begin{array}{r}-0.035^{+} \\
(0.021)\end{array}$ & $\begin{array}{c}0.002 \\
(0.038)\end{array}$ & $\begin{array}{l}-0.008 \\
(0.023)\end{array}$ \\
\hline CASMIN Intermediate vocational (2a) & $\begin{array}{c}-0.036^{+} \\
(0.020)\end{array}$ & $\begin{array}{l}-0.009 \\
(0.034)\end{array}$ & $\begin{array}{l}-0.019 \\
(0.021)\end{array}$ \\
\hline CASMIN General maturity (2c_gen) & $\begin{array}{l}-0.013 \\
(0.032)\end{array}$ & $\begin{array}{l}-0.023 \\
(0.050)\end{array}$ & $\begin{array}{l}-0.023 \\
(0.030)\end{array}$ \\
\hline CASMIN Vocational maturity (2c_voc) & $\begin{array}{l}-0.025 \\
(0.026)\end{array}$ & $\begin{array}{c}0.045 \\
(0.048)\end{array}$ & $\begin{array}{c}0.007 \\
(0.027)\end{array}$ \\
\hline CASMIN Lower tertiarty (3a) & $\begin{array}{l}-0.026 \\
(0.034)\end{array}$ & $\begin{array}{c}0.329^{* * *} \\
(0.055)\end{array}$ & $\begin{array}{c}0.176^{* * * *} \\
(0.034)\end{array}$ \\
\hline CASMIN Higher tertiary (3b) & $\begin{array}{c}0.235^{* * * *} \\
(0.030)\end{array}$ & $\begin{array}{c}0.595^{* * * *} \\
(0.051)\end{array}$ & $\begin{array}{c}0.428^{* * * *} \\
(0.030)\end{array}$ \\
\hline Constant & $\begin{array}{c}3.225^{* * *} \\
(0.218)\end{array}$ & $\begin{array}{c}3.162 * * * \\
(0.267)\end{array}$ & $\begin{array}{c}3.460 * * * \\
(0.205)\end{array}$ \\
\hline$R^{2}$ & 0.189 & 0.307 & 0.269 \\
\hline
\end{tabular}

Notes: Omitted: survey year dummies, firm size $<10$ (reference category), ISCO-2-digit dummies, NACE top category dummies. Significance levels: ${ }^{+} p<0.1,{ }^{*} p<0.05,{ }^{* *} p<0.01,{ }^{* * *} p<0.001$. Source: SOEP v32 1991-2015, own calculations. 
Table A13: Regression results for decomposition at the mean, using imputed wages (corresponding to Tab 4, columns 9 to 12).

\begin{tabular}{|c|c|c|c|}
\hline & Females $(\mathrm{N}=101,381)$ & Males $(\mathrm{N}=107,382)$ & Pooled $(\mathrm{N}=208,763)$ \\
\hline Female & & & $\begin{array}{c}-0.243^{* * *} \\
(0.007)\end{array}$ \\
\hline Locus of Control & $\begin{array}{c}-0.049^{* * *} \\
(0.005)\end{array}$ & $\begin{array}{c}-0.059^{* * *} \\
(0.005)\end{array}$ & $\begin{array}{c}-0.055^{* * *} \\
(0.003)\end{array}$ \\
\hline Extraversion & $\begin{array}{l}-0.004 \\
(0.005)\end{array}$ & $\begin{array}{r}-0.007^{+} \\
(0.004)\end{array}$ & $\begin{array}{c}-0.007^{*} \\
(0.003)\end{array}$ \\
\hline Agreeableness & $\begin{array}{c}-0.029^{* * *} \\
(0.005)\end{array}$ & $\begin{array}{c}-0.036^{* * *} \\
(0.004)\end{array}$ & $\begin{array}{c}-0.034^{* * *} \\
(0.003)\end{array}$ \\
\hline Conscientiousness & $\begin{array}{l}-0.003 \\
(0.005)\end{array}$ & $\begin{array}{l}-0.001 \\
(0.004)\end{array}$ & $\begin{array}{c}0.001 \\
(0.003)\end{array}$ \\
\hline Neuroticism & $\begin{array}{c}-0.019^{* * *} \\
(0.004)\end{array}$ & $\begin{array}{c}-0.028^{* * *} \\
(0.004)\end{array}$ & $\begin{array}{c}-0.022^{* * *} \\
(0.003)\end{array}$ \\
\hline Openness & $\begin{array}{c}0.002 \\
(0.005)\end{array}$ & $\begin{array}{l}0.008^{+} \\
(0.004)\end{array}$ & $\begin{array}{c}0.003 \\
(0.003)\end{array}$ \\
\hline Positive reciprocity & $\begin{array}{c}0.015^{* * *} \\
(0.004)\end{array}$ & $\begin{array}{c}0.018^{* * *} \\
(0.005)\end{array}$ & $\begin{array}{c}0.016^{* * *} \\
(0.003)\end{array}$ \\
\hline Negative reciprocity & $\begin{array}{l}-0.007 \\
(0.005)\end{array}$ & $\begin{array}{c}0.000 \\
(0.004)\end{array}$ & $\begin{array}{l}-0.003 \\
(0.003)\end{array}$ \\
\hline Risk taking & $\begin{array}{c}-0.007^{+} \\
(0.004)\end{array}$ & $\begin{array}{l}0.007^{+} \\
(0.004)\end{array}$ & $\begin{array}{c}0.001 \\
(0.003)\end{array}$ \\
\hline Age & $\begin{array}{c}0.072^{* * *} \\
(0.002)\end{array}$ & $\begin{array}{c}0.083^{* * *} \\
(0.002)\end{array}$ & $\begin{array}{c}0.076^{* * *} \\
(0.002)\end{array}$ \\
\hline $\mathrm{Age}^{2} / 100$ & $\begin{array}{c}-0.075^{* * *} \\
(0.003)\end{array}$ & $\begin{array}{c}-0.085^{* * *} \\
(0.003)\end{array}$ & $\begin{array}{c}-0.078^{* * *} \\
(0.002)\end{array}$ \\
\hline CASMIN General elementary (1b) & $\begin{array}{c}0.043 \\
(0.034)\end{array}$ & $\begin{array}{l}0.080^{+} \\
(0.045)\end{array}$ & $\begin{array}{l}0.057^{*} \\
(0.029)\end{array}$ \\
\hline CASMIN Basic vocational (1c) & $\begin{array}{c}0.200^{* * *} \\
(0.033)\end{array}$ & $\begin{array}{c}0.244^{* * *} \\
(0.043)\end{array}$ & $\begin{array}{c}0.237^{* * *} \\
(0.028)\end{array}$ \\
\hline CASMIN Intermediate general (2b) & $\begin{array}{c}0.109^{* *} \\
(0.038)\end{array}$ & $\begin{array}{c}0.064 \\
(0.048)\end{array}$ & $\begin{array}{c}0.091^{* *} \\
(0.031)\end{array}$ \\
\hline CASMIN Intermediate vocational (2a) & $\begin{array}{c}0.393^{* * *} \\
(0.033)\end{array}$ & $\begin{array}{c}0.380^{* * *} \\
(0.043)\end{array}$ & $\begin{array}{c}0.392^{* * *} \\
(0.028)\end{array}$ \\
\hline CASMIN General maturity (2c_gen) & $\begin{array}{c}0.128^{* * *} \\
(0.039)\end{array}$ & $\begin{array}{l}0.124^{*} \\
(0.049)\end{array}$ & $\begin{array}{c}0.137^{* * *} \\
(0.032)\end{array}$ \\
\hline CASMIN Vocational maturity (2c_voc) & $\begin{array}{c}0.519^{* * *} \\
(0.035)\end{array}$ & $\begin{array}{c}0.476^{* * *} \\
(0.045)\end{array}$ & $\begin{array}{c}0.511^{* * *} \\
(0.029)\end{array}$ \\
\hline CASMIN Lower tertiarty (3a) & $\begin{array}{c}0.657^{* * *} \\
(0.036)\end{array}$ & $\begin{array}{c}0.661^{* * *} \\
(0.045)\end{array}$ & $\begin{array}{c}0.679^{* * *} \\
(0.030)\end{array}$ \\
\hline CASMIN Higher tertiary (3b) & $\begin{array}{c}0.776^{* * *} \\
(0.035)\end{array}$ & $\begin{array}{c}0.758^{* * *} \\
(0.044)\end{array}$ & $\begin{array}{c}0.781^{* * *} \\
(0.029)\end{array}$ \\
\hline East Germany $(0 / 1)$ & $\begin{array}{c}-0.345^{* * *} \\
(0.011)\end{array}$ & $\begin{array}{c}-0.488^{* * *} \\
(0.011)\end{array}$ & $\begin{array}{c}-0.421^{* * *} \\
(0.008)\end{array}$ \\
\hline Married (0/1) & $\begin{array}{c}-0.028^{* *} \\
(0.009)\end{array}$ & $\begin{array}{c}0.113^{* * *} \\
(0.010)\end{array}$ & $\begin{array}{c}0.046^{* * *} \\
(0.006)\end{array}$ \\
\hline Child under $16(0 / 1)$ & $\begin{array}{c}-0.070^{* * *} \\
(0.008)\end{array}$ & $\begin{array}{c}0.012 \\
(0.008)\end{array}$ & $\begin{array}{c}-0.017^{* *} \\
(0.006)\end{array}$ \\
\hline Constant & $\begin{array}{c}0.441^{* * *} \\
(0.057)\end{array}$ & $\begin{array}{c}0.383^{* * *} \\
(0.062)\end{array}$ & $\begin{array}{c}0.557^{* * *} \\
(0.043)\end{array}$ \\
\hline$R^{2}$ & 0.291 & 0.403 & 0.372 \\
\hline
\end{tabular}

Notes: Omitted: survey year dummies. Significance levels: ${ }^{+} p<0.1,{ }^{*} p<0.05,{ }^{* *} p<0.01,{ }^{* * *} p<0.001$. Source: SOEP v32 1991-2015, own calculations. 
Table A14: Regression results for decomposition at the 10th percentile, using imputed wages (corresponding to Tab 4, columns 9 to 12).

\begin{tabular}{|c|c|c|c|}
\hline & Females $(\mathrm{N}=101,381)$ & Males $(\mathrm{N}=107,382)$ & Pooled $(\mathrm{N}=208,763)$ \\
\hline Female & & & $\begin{array}{c}-0.220^{* * *} \\
(0.014)\end{array}$ \\
\hline Locus of Control & $\begin{array}{c}-0.065^{* * *} \\
(0.011)\end{array}$ & $\begin{array}{c}-0.040^{* * *} \\
(0.008)\end{array}$ & $\begin{array}{c}-0.053^{* * *} \\
(0.007)\end{array}$ \\
\hline Extraversion & $\begin{array}{c}-0.014 \\
(0.011)\end{array}$ & $\begin{array}{c}-0.007 \\
(0.008)\end{array}$ & $\begin{array}{l}-0.009 \\
(0.007)\end{array}$ \\
\hline Agreeableness & $\begin{array}{r}-0.018^{+} \\
(0.011)\end{array}$ & $\begin{array}{c}-0.028^{* * *} \\
(0.007)\end{array}$ & $\begin{array}{c}-0.028^{* * *} \\
(0.006)\end{array}$ \\
\hline Conscientiousness & $\begin{array}{c}0.007 \\
(0.011)\end{array}$ & $\begin{array}{c}0.028^{* * *} \\
(0.008)\end{array}$ & $\begin{array}{c}0.022^{* * *} \\
(0.006)\end{array}$ \\
\hline Neuroticism & $\begin{array}{c}-0.024^{*} \\
(0.010)\end{array}$ & $\begin{array}{c}-0.030^{* * *} \\
(0.008)\end{array}$ & $\begin{array}{c}-0.024^{* * *} \\
(0.006)\end{array}$ \\
\hline Openness & $\begin{array}{l}-0.009 \\
(0.011)\end{array}$ & $\begin{array}{r}-0.014^{+} \\
(0.008)\end{array}$ & $\begin{array}{c}-0.013^{+} \\
(0.007)\end{array}$ \\
\hline Positive reciprocity & $\begin{array}{l}0.026^{*} \\
(0.011)\end{array}$ & $\begin{array}{c}0.030^{* * *} \\
(0.009)\end{array}$ & $\begin{array}{c}0.028^{* * *} \\
(0.007)\end{array}$ \\
\hline Negative reciprocity & $\begin{array}{l}-0.002 \\
(0.012)\end{array}$ & $\begin{array}{l}-0.000 \\
(0.008)\end{array}$ & $\begin{array}{l}-0.002 \\
(0.007)\end{array}$ \\
\hline Risk taking & $\begin{array}{c}-0.036^{* * *} \\
(0.009)\end{array}$ & $\begin{array}{c}-0.021^{* *} \\
(0.007)\end{array}$ & $\begin{array}{c}-0.030^{* * *} \\
(0.006)\end{array}$ \\
\hline Age & $\begin{array}{c}0.183^{* * *} \\
(0.006)\end{array}$ & $\begin{array}{c}0.201^{* * *} \\
(0.005)\end{array}$ & $\begin{array}{c}0.192^{* * *} \\
(0.004)\end{array}$ \\
\hline $\operatorname{Age}^{2} / 100$ & $\begin{array}{c}-0.203^{* * *} \\
(0.008)\end{array}$ & $\begin{array}{c}-0.222^{* * *} \\
(0.006)\end{array}$ & $\begin{array}{c}-0.212^{* * *} \\
(0.005)\end{array}$ \\
\hline CASMIN General elementary (1b) & $\begin{array}{c}0.161 \\
(0.101)\end{array}$ & $\begin{array}{c}0.177^{+} \\
(0.107)\end{array}$ & $\begin{array}{l}0.162^{*} \\
(0.074)\end{array}$ \\
\hline CASMIN Basic vocational (1c) & $\begin{array}{c}0.410^{* * *} \\
(0.097)\end{array}$ & $\begin{array}{c}0.518^{* * *} \\
(0.100)\end{array}$ & $\begin{array}{c}0.492^{* * *} \\
(0.070)\end{array}$ \\
\hline CASMIN Intermediate general $(2 b)$ & $\begin{array}{l}-0.178 \\
(0.112)\end{array}$ & $\begin{array}{c}-0.412^{* * *} \\
(0.121)\end{array}$ & $\begin{array}{c}-0.281^{* * *} \\
(0.083)\end{array}$ \\
\hline CASMIN Intermediate vocational (2a) & $\begin{array}{c}0.676^{* * *} \\
(0.096)\end{array}$ & $\begin{array}{c}0.614^{* * *} \\
(0.100)\end{array}$ & $\begin{array}{c}0.648^{* * *} \\
(0.070)\end{array}$ \\
\hline CASMIN General maturity (2c_gen) & $\begin{array}{c}-0.316^{* *} \\
(0.115)\end{array}$ & $\begin{array}{c}-0.276^{*} \\
(0.116)\end{array}$ & $\begin{array}{c}-0.290^{* * *} \\
(0.082)\end{array}$ \\
\hline CASMIN Vocational maturity (2c_voc) & $\begin{array}{c}0.824^{* * *} \\
(0.098)\end{array}$ & $\begin{array}{c}0.614^{* * *} \\
(0.102)\end{array}$ & $\begin{array}{c}0.732^{* * *} \\
(0.071)\end{array}$ \\
\hline CASMIN Lower tertiarty (3a) & $\begin{array}{c}0.945^{* * *} \\
(0.099)\end{array}$ & $\begin{array}{c}0.618^{* * *} \\
(0.101)\end{array}$ & $\begin{array}{c}0.771^{* * *} \\
(0.071)\end{array}$ \\
\hline CASMIN Higher tertiary (3b) & $\begin{array}{c}0.914^{* * *} \\
(0.096)\end{array}$ & $\begin{array}{c}0.665^{* * *} \\
(0.100)\end{array}$ & $\begin{array}{c}0.792^{* * *} \\
(0.070)\end{array}$ \\
\hline East Germany $(0 / 1)$ & $\begin{array}{c}-0.508^{* * *} \\
(0.028)\end{array}$ & $\begin{array}{c}-0.358^{* * *} \\
(0.021)\end{array}$ & $\begin{array}{c}-0.430^{* * *} \\
(0.017)\end{array}$ \\
\hline Married (0/1) & $\begin{array}{l}-0.031 \\
(0.020)\end{array}$ & $\begin{array}{c}0.141^{* * *} \\
(0.017)\end{array}$ & $\begin{array}{c}0.055^{* * *} \\
(0.013)\end{array}$ \\
\hline Child under $16(0 / 1)$ & $\begin{array}{c}-0.208^{* * *} \\
(0.019)\end{array}$ & $\begin{array}{c}-0.105^{* * *} \\
(0.014)\end{array}$ & $\begin{array}{c}-0.146^{* * *} \\
(0.012)\end{array}$ \\
\hline Constant & $\begin{array}{c}-3.035^{* * *} \\
(0.160)\end{array}$ & $\begin{array}{c}-2.949^{* * *} \\
(0.149)\end{array}$ & $\begin{array}{c}-2.869^{* * *} \\
(0.110)\end{array}$ \\
\hline$R^{2}$ & 0.126 & 0.197 & 0.155 \\
\hline
\end{tabular}

Notes: Omitted: survey year dummies. Significance levels: ${ }^{+} p<0.1,{ }^{*} p<0.05,{ }^{* *} p<0.01,{ }^{* * *} p<0.001$. Source: SOEP v32 1991-2015, own calculations. 
Table A15: Regression results for decomposition at the 50th percentile, using imputed wages (corresponding to Tab 4, columns 9 to 12).

\begin{tabular}{|c|c|c|c|}
\hline & Females $(\mathrm{N}=101,381)$ & Males $(\mathrm{N}=107,382)$ & Pooled $(\mathrm{N}=208,763)$ \\
\hline Female & & & $\begin{array}{c}-0.242^{* * *} \\
(0.007)\end{array}$ \\
\hline Locus of Control & $\begin{array}{c}-0.040^{* * *} \\
(0.005)\end{array}$ & $\begin{array}{c}-0.043^{* * *} \\
(0.005)\end{array}$ & $\begin{array}{c}-0.042^{* * *} \\
(0.003)\end{array}$ \\
\hline Extraversion & $\begin{array}{c}-0.008^{+} \\
(0.005)\end{array}$ & $\begin{array}{l}-0.005 \\
(0.005)\end{array}$ & $\begin{array}{c}-0.006^{+} \\
(0.003)\end{array}$ \\
\hline Agreeableness & $\begin{array}{c}-0.030^{* * *} \\
(0.005)\end{array}$ & $\begin{array}{c}-0.030^{* * *} \\
(0.004)\end{array}$ & $\begin{array}{c}-0.031^{* * *} \\
(0.003)\end{array}$ \\
\hline Conscientiousness & $\begin{array}{c}-0.011^{*} \\
(0.005)\end{array}$ & $\begin{array}{c}-0.014^{* * *} \\
(0.004)\end{array}$ & $\begin{array}{c}-0.010^{* *} \\
(0.003)\end{array}$ \\
\hline Neuroticism & $\begin{array}{c}-0.016^{* * *} \\
(0.005)\end{array}$ & $\begin{array}{c}-0.021^{* * *} \\
(0.005)\end{array}$ & $\begin{array}{c}-0.017^{* * *} \\
(0.003)\end{array}$ \\
\hline Openness & $\begin{array}{c}0.007 \\
(0.005)\end{array}$ & $\begin{array}{l}0.009^{*} \\
(0.005)\end{array}$ & $\begin{array}{l}0.006^{+} \\
(0.003)\end{array}$ \\
\hline Positive reciprocity & $\begin{array}{l}0.010^{*} \\
(0.005)\end{array}$ & $\begin{array}{c}0.008 \\
(0.005)\end{array}$ & $\begin{array}{l}0.009^{*} \\
(0.004)\end{array}$ \\
\hline Negative reciprocity & $\begin{array}{c}-0.013^{* *} \\
(0.005)\end{array}$ & $\begin{array}{l}-0.004 \\
(0.005)\end{array}$ & $\begin{array}{c}-0.009^{*} \\
(0.003)\end{array}$ \\
\hline Risk taking & $\begin{array}{l}-0.003 \\
(0.004)\end{array}$ & $\begin{array}{c}-0.002 \\
(0.004)\end{array}$ & $\begin{array}{l}-0.001 \\
(0.003)\end{array}$ \\
\hline Age & $\begin{array}{c}0.058^{* * *} \\
(0.002)\end{array}$ & $\begin{array}{c}0.069^{* * *} \\
(0.002)\end{array}$ & $\begin{array}{c}0.062^{* * *} \\
(0.002)\end{array}$ \\
\hline $\operatorname{Age}^{2} / 100$ & $\begin{array}{c}-0.059^{* * *} \\
(0.003)\end{array}$ & $\begin{array}{c}-0.072^{* * *} \\
(0.003)\end{array}$ & $\begin{array}{c}-0.064^{* * *} \\
(0.002)\end{array}$ \\
\hline CASMIN General elementary (1b) & $\begin{array}{c}0.009 \\
(0.024)\end{array}$ & $\begin{array}{l}-0.008 \\
(0.036)\end{array}$ & $\begin{array}{l}-0.010 \\
(0.023)\end{array}$ \\
\hline CASMIN Basic vocational (1c) & $\begin{array}{c}0.146^{* * *} \\
(0.024)\end{array}$ & $\begin{array}{c}0.122^{* * *} \\
(0.034)\end{array}$ & $\begin{array}{c}0.155^{* * *} \\
(0.022)\end{array}$ \\
\hline CASMIN Intermediate general $(2 b)$ & $\begin{array}{c}0.244^{* * *} \\
(0.029)\end{array}$ & $\begin{array}{l}0.072^{+} \\
(0.039)\end{array}$ & $\begin{array}{c}0.150^{* * *} \\
(0.025)\end{array}$ \\
\hline CASMIN Intermediate vocational (2a) & $\begin{array}{c}0.360^{* * *} \\
(0.024)\end{array}$ & $\begin{array}{c}0.193^{* * *} \\
(0.034)\end{array}$ & $\begin{array}{c}0.274^{* * *} \\
(0.022)\end{array}$ \\
\hline CASMIN General maturity (2c_gen) & $\begin{array}{c}0.241^{* * *} \\
(0.029)\end{array}$ & $\begin{array}{c}0.019 \\
(0.037)\end{array}$ & $\begin{array}{c}0.131^{* * *} \\
(0.025)\end{array}$ \\
\hline CASMIN Vocational maturity (2c_voc) & $\begin{array}{c}0.509^{* * *} \\
(0.027)\end{array}$ & $\begin{array}{c}0.303^{* * *} \\
(0.036)\end{array}$ & $\begin{array}{c}0.411^{* * *} \\
(0.024)\end{array}$ \\
\hline CASMIN Lower tertiarty (3a) & $\begin{array}{c}0.659^{* * *} \\
(0.030)\end{array}$ & $\begin{array}{c}0.423^{* * *} \\
(0.036)\end{array}$ & $\begin{array}{c}0.550^{* * *} \\
(0.024)\end{array}$ \\
\hline CASMIN Higher tertiary (3b) & $\begin{array}{c}0.725^{* * *} \\
(0.025)\end{array}$ & $\begin{array}{c}0.470^{* * *} \\
(0.034)\end{array}$ & $\begin{array}{c}0.604^{* * *} \\
(0.023)\end{array}$ \\
\hline East Germany $(0 / 1)$ & $\begin{array}{c}-0.294^{* * *} \\
(0.011)\end{array}$ & $\begin{array}{c}-0.506^{* * *} \\
(0.011)\end{array}$ & $\begin{array}{c}-0.400^{* * *} \\
(0.008)\end{array}$ \\
\hline Married (0/1) & $\begin{array}{c}-0.044^{* * *} \\
(0.010)\end{array}$ & $\begin{array}{c}0.090^{* * *} \\
(0.010)\end{array}$ & $\begin{array}{c}0.024^{* * *} \\
(0.007)\end{array}$ \\
\hline Child under $16(0 / 1)$ & $\begin{array}{c}-0.052^{* * *} \\
(0.009)\end{array}$ & $\begin{array}{c}0.009 \\
(0.008)\end{array}$ & $\begin{array}{c}-0.011^{+} \\
(0.006)\end{array}$ \\
\hline Constant & $\begin{array}{c}0.825^{* * *} \\
(0.050)\end{array}$ & $\begin{array}{c}0.999^{* * *} \\
(0.053)\end{array}$ & $\begin{array}{c}1.053^{* * *} \\
(0.038)\end{array}$ \\
\hline$R^{2}$ & 0.227 & 0.293 & 0.277 \\
\hline
\end{tabular}

Notes: Omitted: survey year dummies. Significance levels: ${ }^{+} p<0.1,{ }^{*} p<0.05,{ }^{* *} p<0.01,{ }^{* * *} p<0.001$. Source: SOEP v32 1991-2015, own calculations. 
Table A16: Regression results for decomposition at the 90th percentile, using imputed wages (corresponding to Tab 4, columns 9 to 12).

\begin{tabular}{|c|c|c|c|}
\hline & Females $(\mathrm{N}=101,381)$ & Males $(\mathrm{N}=107,382)$ & Pooled $(\mathrm{N}=208,763)$ \\
\hline Female & & & $\begin{array}{c}-0.267^{* * *} \\
(0.011)\end{array}$ \\
\hline Locus of Control & $\begin{array}{c}-0.044^{* * *} \\
(0.006)\end{array}$ & $\begin{array}{c}-0.088^{* * *} \\
(0.009)\end{array}$ & $\begin{array}{c}-0.069^{* * *} \\
(0.005)\end{array}$ \\
\hline Extraversion & $\begin{array}{c}0.002 \\
(0.006)\end{array}$ & $\begin{array}{c}-0.008 \\
(0.009)\end{array}$ & $\begin{array}{l}-0.008 \\
(0.006)\end{array}$ \\
\hline Agreeableness & $\begin{array}{c}-0.035^{* * *} \\
(0.006)\end{array}$ & $\begin{array}{c}-0.053^{* * *} \\
(0.009)\end{array}$ & $\begin{array}{c}-0.043^{* * *} \\
(0.006)\end{array}$ \\
\hline Conscientiousness & $\begin{array}{c}-0.004 \\
(0.006)\end{array}$ & $\begin{array}{c}-0.003 \\
(0.009)\end{array}$ & $\begin{array}{l}-0.001 \\
(0.006)\end{array}$ \\
\hline Neuroticism & $\begin{array}{c}-0.010^{+} \\
(0.006)\end{array}$ & $\begin{array}{c}-0.034^{* * *} \\
(0.009)\end{array}$ & $\begin{array}{c}-0.019^{* * *} \\
(0.005)\end{array}$ \\
\hline Openness & $\begin{array}{l}-0.005 \\
(0.006)\end{array}$ & $\begin{array}{c}0.014 \\
(0.009)\end{array}$ & $\begin{array}{c}0.004 \\
(0.005)\end{array}$ \\
\hline Positive reciprocity & $\begin{array}{l}0.012^{*} \\
(0.006)\end{array}$ & $\begin{array}{l}0.019 * \\
(0.009)\end{array}$ & $\begin{array}{c}0.015^{* *} \\
(0.006)\end{array}$ \\
\hline Negative reciprocity & $\begin{array}{c}0.002 \\
(0.006)\end{array}$ & $\begin{array}{c}0.004 \\
(0.008)\end{array}$ & $\begin{array}{c}0.003 \\
(0.005)\end{array}$ \\
\hline Risk taking & $\begin{array}{l}0.011^{*} \\
(0.005)\end{array}$ & $\begin{array}{c}0.040^{* * *} \\
(0.008)\end{array}$ & $\begin{array}{c}0.028^{* * *} \\
(0.005)\end{array}$ \\
\hline Age & $\begin{array}{l}-0.001 \\
(0.003)\end{array}$ & $\begin{array}{c}0.006 \\
(0.004)\end{array}$ & $\begin{array}{c}-0.002 \\
(0.003)\end{array}$ \\
\hline $\operatorname{Age}^{2} / 100$ & $\begin{array}{c}0.011^{* *} \\
(0.004)\end{array}$ & $\begin{array}{l}0.012^{*} \\
(0.005)\end{array}$ & $\begin{array}{c}0.018^{* * *} \\
(0.004)\end{array}$ \\
\hline CASMIN General elementary (1b) & $\begin{array}{c}-0.067^{* * *} \\
(0.020)\end{array}$ & $\begin{array}{c}-0.096^{* *} \\
(0.030)\end{array}$ & $\begin{array}{c}-0.076^{* * *} \\
(0.019)\end{array}$ \\
\hline CASMIN Basic vocational (1c) & $\begin{array}{c}-0.050^{*} \\
(0.021)\end{array}$ & $\begin{array}{c}-0.076^{* *} \\
(0.029)\end{array}$ & $\begin{array}{c}-0.073^{* * *} \\
(0.019)\end{array}$ \\
\hline CASMIN Intermediate general $(2 b)$ & $\begin{array}{c}0.028 \\
(0.022)\end{array}$ & $\begin{array}{c}0.144^{* * *} \\
(0.037)\end{array}$ & $\begin{array}{c}0.103^{* * *} \\
(0.022)\end{array}$ \\
\hline CASMIN Intermediate vocational (2a) & $\begin{array}{l}0.038^{+} \\
(0.021)\end{array}$ & $\begin{array}{c}0.186^{* * *} \\
(0.032)\end{array}$ & $\begin{array}{c}0.129^{* * *} \\
(0.020)\end{array}$ \\
\hline CASMIN General maturity (2c_gen) & $\begin{array}{c}0.104^{* *} \\
(0.032)\end{array}$ & $\begin{array}{c}0.261^{* * *} \\
(0.045)\end{array}$ & $\begin{array}{c}0.213^{* * *} \\
(0.029)\end{array}$ \\
\hline CASMIN Vocational maturity (2c_voc) & $\begin{array}{c}0.090^{* * *} \\
(0.027)\end{array}$ & $\begin{array}{c}0.332^{* * *} \\
(0.046)\end{array}$ & $\begin{array}{c}0.236^{* * *} \\
(0.027)\end{array}$ \\
\hline CASMIN Lower tertiarty (3a) & $\begin{array}{c}0.211^{* * *} \\
(0.036)\end{array}$ & $\begin{array}{c}0.838^{* * *} \\
(0.054)\end{array}$ & $\begin{array}{c}0.591^{* * *} \\
(0.036)\end{array}$ \\
\hline CASMIN Higher tertiary (3b) & $\begin{array}{c}0.606^{* * *} \\
(0.034)\end{array}$ & $\begin{array}{c}1.129^{* * *} \\
(0.043)\end{array}$ & $\begin{array}{c}0.899^{* * *} \\
(0.028)\end{array}$ \\
\hline East Germany $(0 / 1)$ & $\begin{array}{c}-0.175^{* * *} \\
(0.014)\end{array}$ & $\begin{array}{c}-0.477^{* * *} \\
(0.020)\end{array}$ & $\begin{array}{c}-0.347^{* * *} \\
(0.012)\end{array}$ \\
\hline Married (0/1) & $\begin{array}{c}-0.006 \\
(0.013)\end{array}$ & $\begin{array}{c}0.095^{* * *} \\
(0.019)\end{array}$ & $\begin{array}{c}0.059^{* * *} \\
(0.011)\end{array}$ \\
\hline Child under $16(0 / 1)$ & $\begin{array}{c}0.051^{* * *} \\
(0.011)\end{array}$ & $\begin{array}{c}0.156^{* * *} \\
(0.016)\end{array}$ & $\begin{array}{c}0.120^{* * *} \\
(0.010)\end{array}$ \\
\hline Constant & $\begin{array}{c}2.874^{* * *} \\
(0.059)\end{array}$ & $\begin{array}{c}2.546^{* * *} \\
(0.084)\end{array}$ & $\begin{array}{c}2.897^{* * *} \\
(0.053)\end{array}$ \\
\hline$R^{2}$ & 0.118 & 0.230 & 0.197 \\
\hline
\end{tabular}

Notes: Omitted: survey year dummies. Significance levels: ${ }^{+} p<0.1,{ }^{*} p<0.05,{ }^{* *} p<0.01,{ }^{* * *} p<0.001$. Source: SOEP v32 1991-2015, own calculations. 


\section{Appendix B: Additional analyses using UK and Australian data}

\section{B1. Data}

\section{Estimation sample}

This supplement provides additional evidence on the impact of personality traits on gender wage gap with data from the UK and Australia. I use the UK's Understanding Society (UKHLS) from 2009 to 2015 and the Household, Income and Labour Dynamics in Australia (HILDA, Wooden and Watson, 2007) survey from 2001 to 2015. I chose these specific countries and surveys, in addition to the SOEP, to investigate the generalizability of the results as the theoretical reasoning does not necessarily imply country differences, at least among different shades of Western capitalist systems.

Both datasets contain information on the respondent's age (and age squared), schooling, marital status, whether a child under the age of 16 (UKHLS) resp. 15 (HILDA) is part of the household, establishment size, full-time employment, occupation (2-digits), industry (major groups) and survey year (dummy variables) which serve as control variables.

Like in the main analysis, the dependent variable is the natural logarithm of hourly wages, calculated from weekly working hours and monthly earnings ${ }^{19}$. All samples are restricted to part- and full-time working employees aged 19 to 65 . Overall, the British sample consists of 68,614 observations for 17,169 individuals and the Australian sample consists of 49,514 observations for 10,007 individuals. ${ }^{20}$

\section{Measures of Personality traits}

Both surveys include measures for the big five personality traits. The UKHLS and the SOEP use the same scale to measure the personality traits. Thus, the items surveyed in the UK are the same as the ones in Germany, as presented in Table A1 of the paper. HILDA uses a more sophisticated

\footnotetext{
${ }^{19}$ I use actual working hours in my analysis. However, the results remain practically unchanged when using contractual working hours.

${ }^{20}$ Tables B1 to B2 in provide summary statistics for controls in the data.
} 
scale that consists of 40 items of which I use 28 in my analysis, in line with Losoncz (2009). The HILDA furthermore surveys locus of control with 7 items. Table B3 shows the survey items as well as reliability ratios used to construct the measures for personality traits in the HILDA.

The preparation of the measures for personality traits follows the procedure outlined in the main analysis. Table B4 shows the means and differences on standardized personality traits by gender and also contains the measures in the SOEP for comparison. Overall, with the exceptions of locus of controls and neuroticism in Australia ${ }^{21}$, the patterns are very comparable across countries.

\section{B2. Results}

\section{Australia (HILDA)}

Table B5 presents the results for the Australian sample. Columns 1 to 4 shows the results for the specification without controlling for occupation and industry. Overall, the results regarding gender wage gaps are comparable to previous findings for Australia (Kee, 2006). Like in Germany, the unexplained gender wage gap increases across the wage distribution, thus pointing to the existence of a glass ceiling.

Personality traits explain $7.7 \%$ of the overall wage gap at the mean and around $12 \%$ at the 90th percentile in Australia in this model. The results are thus remarkably similar to the results with the SOEP. Regarding the role of personality traits as omitted variables, i.e. the reduction of the unexplained gender wage gap when adding controls for personality traits, shows that including personality traits decreases the unexplained gender wage gap by $0.6 \log$ points at the 10th percentile and $2.1 \log$ points at the 90th percentile. Thus, personality traits seem to have an increasing impact on gender gaps along the wage distribution.

Like in the main analysis for Germany, personality traits seem to especially matter in terms of differences in endowments between men and women, with agreeableness driving the effect

\footnotetext{
${ }^{21}$ This descriptive finding concerning Australia is in line with Risse et al. (2018) who use the same data.
} 
and conscientiousness working in favor of women. The role of differential returns seems to be relatively minor, as the only account for $0.6 \%$ of the overall wage gap at the mean and $1.2 \%$ at the 90th percentile.

Adding control variables for occupation and industry in columns 25 to 8 of Table B5 does not significantly change the patterns observed. Like in the main analysis for Germany, the role of personality traits decreases slightly, especially with regards to differential endowment in agreeableness, but personality traits still seem to matter.

In columns 9 to 12 of Table B5, I repeat the exercise concerning sample selection in line with the main analysis and impute missing information on hourly wages in the same manner as with the SOEP. Like in the main analysis, this does not change the overall pattern observed.

\section{United Kingdom (UKHLS)}

Table B6 shows the estimation results for the British sample, beginning with the results without controls for occupation and industry in columns 1 to 4 . At the mean, personality traits can explain $9.5 \%$ of the overall gender wage gap. Across the distribution of wages, this share increases from around $0 \%$ at the 10 th percentile to $13.7 \%$ at the 90 th percentile. Again, the pattern are mostly driven by differences in endowments, especially agreeableness. Thus, the analysis with the UKHLS overall supports the findings from the SOEP and the HILDA.

Like in the other samples, adding controls for occupation and industry (Table B6, columns 5 to 8) does not meaningfully affect the patterns observed and only slightly decreases the overall contribution of personality traits. Like in the other estimations, I impute missing values in the wage variable and present the results in Table B6, columns 9 to 12. Again, this does not meaningfully change the conclusions from the analysis.

Overall, the findings from the analyses using the HILDA and UKHLS support the conclusions based on the main analysis using the SOEP. Personality traits especially matter in terms of differences in endowments between men and women; differential returns to certain traits seem to play a minor role. The impact of personality traits on wage gaps increases across the wage 
distribution. Figure B5 plots the share of the overall wage gap explained by personality traits for all three countries investigated and the three main specifications. As can be seen, the overall patterns are similar across countries, even though the share explained seems to be relatively constant (at least in relative terms; it increases in absolute terms) in Australia. Thus, regardless of the survey items used and country analyzed, the role of personality traits for gender wage gaps is around 7-9\% in the three countries observed and increases across the wage distribution. 
Table B1: Summary statistics for the UKHLS

\begin{tabular}{lrrrr}
\hline & \multicolumn{3}{c}{ Male (N=29,065) } & \multicolumn{2}{c}{ Female (N=39,549) } \\
& Mean & \multicolumn{1}{c}{ SD } & \multicolumn{1}{c}{ Mean } & \multicolumn{1}{c}{ SD } \\
\hline Hourly wage (BGP2010) & 15.735 & 21.275 & 12.948 & 42.728 \\
Age & 40.619 & 11.553 & 40.708 & 11.445 \\
Child in household (dummy) & 0.389 & 0.487 & 0.411 & 0.492 \\
Married (dummy) & 0.107 & 0.309 & 0.096 & 0.295 \\
Full-time employed (dummy) & 0.909 & 0.287 & 0.642 & 0.479 \\
Education: Higher degree & 0.175 & 0.380 & 0.139 & 0.346 \\
Education: 1st degree or equivalent & 0.212 & 0.409 & 0.232 & 0.422 \\
Education: Diploma in he & 0.091 & 0.287 & 0.101 & 0.302 \\
Education: Teaching qual not pgce & 0.009 & 0.096 & 0.021 & 0.143 \\
Education: Nursing/other med qual & 0.007 & 0.082 & 0.045 & 0.208 \\
Education: Other higher degree & 0.002 & 0.046 & 0.002 & 0.041 \\
Education: A level & 0.115 & 0.319 & 0.100 & 0.300 \\
Education: Welsh baccalaureate & 0.000 & 0.012 & 0.000 & 0.012 \\
Education: I'nationl baccalaureate & 0.001 & 0.035 & 0.001 & 0.024 \\
Education: AS level & 0.013 & 0.114 & 0.013 & 0.114 \\
Education: Highers (scot) & 0.015 & 0.121 & 0.014 & 0.119 \\
Education: Cert 6th year studies & 0.003 & 0.056 & 0.004 & 0.064 \\
Education: GCSE/O level & 0.268 & 0.443 & 0.248 & 0.432 \\
Education: CSE & 0.057 & 0.233 & 0.056 & 0.229 \\
Education: Standard/o/lower & 0.017 & 0.130 & 0.013 & 0.113 \\
Education: Other school cert & 0.014 & 0.117 & 0.010 & 0.099 \\
Firm size <25 & 0.280 & 0.449 & 0.313 & 0.464 \\
Firm size 25-99 & 0.242 & 0.428 & 0.279 & 0.448 \\
Firm size 100+ & 0.477 & 0.499 & 0.408 & 0.491 \\
\hline
\end{tabular}

Notes: Based on 68,614 observations. ISCO (2-digit) and SIC (top groups) are not shown but included in the data. Source: UKHLS 2009-2015. 
Table B2: Summary statistics for the HILDA

\begin{tabular}{lrrrr}
\hline & \multicolumn{2}{c}{ Male (N=25,670) } & \multicolumn{2}{c}{ Female (N=23,844) } \\
& Mean & \multicolumn{1}{c}{ SD } & Mean & \multicolumn{1}{c}{ SD } \\
\hline Hourly wage (AUD2010) & 32.455 & 17.083 & 26.523 & 11.477 \\
Age & 40.050 & 11.574 & 39.961 & 11.681 \\
Child in household (dummy) & 0.357 & 0.479 & 0.317 & 0.465 \\
Married (dummy) & 0.742 & 0.438 & 0.677 & 0.468 \\
Full-time employed (dummy) & 0.901 & 0.299 & 0.600 & 0.490 \\
Education: Masters or above & 0.065 & 0.247 & 0.065 & 0.247 \\
Education: Grad diploma & 0.069 & 0.254 & 0.097 & 0.295 \\
Education: Bachelor & 0.173 & 0.378 & 0.223 & 0.416 \\
Education: Diploma & 0.106 & 0.308 & 0.113 & 0.317 \\
Education: Cert III/IV & 0.279 & 0.449 & 0.162 & 0.369 \\
Education: Year 12 & 0.151 & 0.358 & 0.158 & 0.364 \\
Education: Year 11 and below & 0.156 & 0.363 & 0.182 & 0.386 \\
Firm size <20 & 0.035 & 0.184 & 0.036 & 0.186 \\
Firm size 20-99 & 0.112 & 0.315 & 0.091 & 0.288 \\
Firm size 100-499 & 0.200 & 0.400 & 0.190 & 0.393 \\
Firm size 500-999 & 0.094 & 0.292 & 0.079 & 0.270 \\
Firm size 1000-4999 & 0.199 & 0.399 & 0.161 & 0.367 \\
Firm size 5000-19999 & 0.176 & 0.381 & 0.170 & 0.376 \\
Firm size 20000+ & 0.184 & 0.388 & 0.273 & 0.445 \\
\hline Notes: Based 0 49,514 & & &
\end{tabular}

Notes: Based on 49,514 observations. ISCO (2-digit) and ANZSIC06 (top groups) are not shown but included in the data. Source: HILDA 2001-2015. 
Table B3: Personality traits in the HILDA

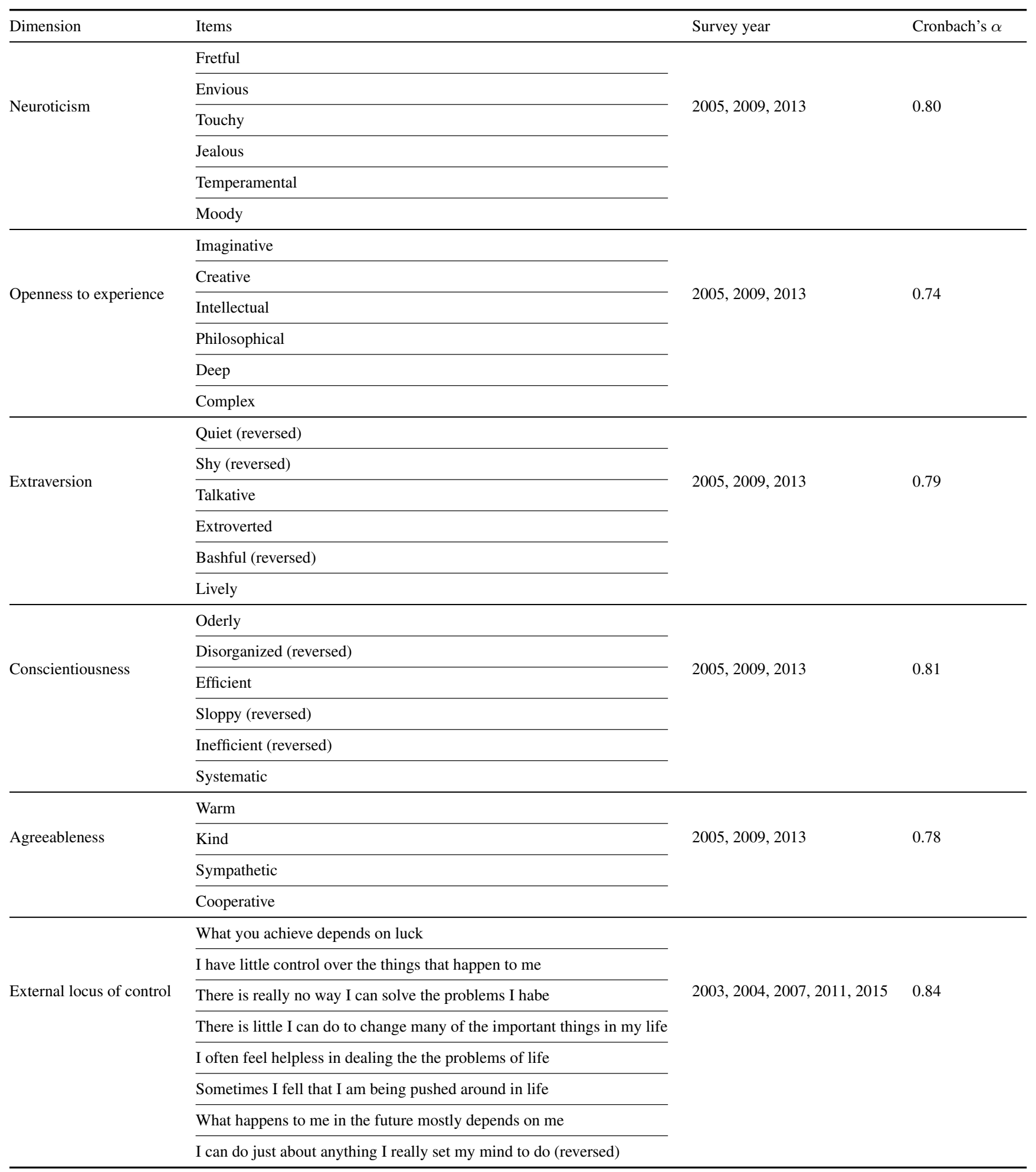

Notes: The big five are surveyed with the question "How well do the following words describe you?". Source: HILDA 2001-2015. 
Table B4: Descriptive statistics of personality traits by gender.

\begin{tabular}{|c|c|c|c|c|c|c|c|c|c|}
\hline & \multicolumn{3}{|c|}{ Germany (SOEP, N=152,777) } & \multicolumn{3}{|c|}{ UK (UKHLS, N=68,614) } & \multicolumn{3}{|c|}{ Australia (HILDA, N=49,514) } \\
\hline & Male & Female & Difference & Male & Female & Difference & Male & Female & Difference \\
\hline Extraversion & -0.109 & 0.141 & $-0.249^{* * *}$ & -0.118 & 0.132 & $-0.250^{* * *}$ & -0.128 & 0.138 & $-0.266^{* * *}$ \\
\hline Agreeableness & -0.170 & 0.147 & $-0.318^{* * *}$ & -0.175 & 0.157 & $-0.332^{* * *}$ & -0.238 & 0.270 & $-0.508^{* * *}$ \\
\hline Conscientiousness & -0.033 & 0.117 & $-0.150^{* * *}$ & -0.057 & 0.193 & $-0.250^{* * *}$ & -0.016 & 0.203 & $-0.220^{* * *}$ \\
\hline Neuroticism & -0.268 & 0.112 & $-0.380^{* * *}$ & -0.271 & 0.109 & $-0.380^{* * *}$ & 0.019 & 0.022 & -0.003 \\
\hline Openness & -0.074 & 0.089 & $-0.162^{* * *}$ & 0.135 & -0.011 & $0.146^{* * *}$ & 0.054 & -0.045 & $0.099^{* * *}$ \\
\hline External locus of control & -0.135 & -0.019 & $-0.116^{* * *}$ & & & & -0.109 & -0.099 & -0.010 \\
\hline Positive reciprocity & 0.050 & 0.027 & $0.023^{* * *}$ & & & & & & \\
\hline Negative reciprocity & 0.146 & -0.131 & $0.276^{* * *}$ & & & & & & \\
\hline Risk taking & 0.218 & -0.139 & $0.357^{* * *}$ & & & & & & \\
\hline
\end{tabular}

Notes: Mean values of personality traits by gender and comparisons of these via t-tests. Significance levels: ${ }^{*} p<0.05,{ }^{* *} p<0.01,{ }^{* * *} p<0.001$. Sources: SOEP v32 1991-2015, UKHLS 2009-2015, HILDA 2001-2015. 
Table B5: Results of the FFL-decompositions for Australia.

\begin{tabular}{|c|c|c|c|c|c|c|c|c|c|c|c|c|}
\hline & \multicolumn{4}{|c|}{ w/o Occupation and Industry $(\mathrm{N}=49,514)$} & \multicolumn{4}{|c|}{ w/ Occupation and Industry $(\mathrm{N}=49,514)$} & \multicolumn{4}{|c|}{ Accounting for selection $(\mathrm{N}=104,704)$} \\
\hline & $\begin{array}{c}\text { Mean } \\
\text { (1) }\end{array}$ & $\begin{array}{c}10^{t h} \\
\text { Percentile } \\
\text { (2) }\end{array}$ & $\begin{array}{c}50^{t h} \\
\text { Percentile } \\
\text { (3) }\end{array}$ & $\begin{array}{c}90^{t h} \\
\text { Percentile } \\
\quad(4)\end{array}$ & $\begin{array}{c}\text { Mean } \\
\text { (5) }\end{array}$ & $\begin{array}{l}10^{t h} \\
\text { Percentile } \\
\quad(6)\end{array}$ & $\begin{array}{c}50^{t h} \\
\text { Percentile } \\
\quad(7)\end{array}$ & $\begin{array}{c}90^{t h} \\
\text { Percentile } \\
\quad(8)\end{array}$ & $\begin{array}{c}\text { Mean } \\
\text { Percentile } \\
\text { (9) }\end{array}$ & $\begin{array}{l}10^{t h} \\
\text { Percentile } \\
\quad(10)\end{array}$ & $\begin{array}{c}50^{t h} \\
\text { Percentile } \\
(11)\end{array}$ & $\begin{array}{l}90^{t h} \\
\text { Percentile } \\
\quad(12)\end{array}$ \\
\hline Raw gap & $\begin{array}{l}0.168^{* * *} \\
(0.009)\end{array}$ & $\begin{array}{l}0.091^{* * *} \\
(0.009)\end{array}$ & $\begin{array}{l}0.158^{* * *} \\
(0.009)\end{array}$ & $\begin{array}{l}0.255^{* * *} \\
(0.015)\end{array}$ & $\begin{array}{l}0.168^{* * *} \\
(0.008)\end{array}$ & $\begin{array}{l}0.091^{* * *} \\
(0.009)\end{array}$ & $\begin{array}{l}0.158^{* * *} \\
(0.009)\end{array}$ & $\begin{array}{l}0.255^{* * *} \\
(0.014)\end{array}$ & $\begin{array}{l}0.119^{* * *} \\
(0.008)\end{array}$ & $\begin{array}{l}0.047^{* * *} \\
(0.011)\end{array}$ & $\begin{array}{l}0.120^{* * *} \\
(0.008)\end{array}$ & $\begin{array}{l}0.202^{* * *} \\
(0.013)\end{array}$ \\
\hline \multicolumn{13}{|c|}{ (A) without personality traits } \\
\hline Unexplained & $\begin{array}{c}0.003 \\
(0.006) \\
0.165^{* * *} \\
(0.008) \\
\end{array}$ & $\begin{array}{c}0.020^{* * *} \\
(0.005) \\
0.071^{* * *} \\
(0.009) \\
\end{array}$ & $\begin{array}{c}0.001 \\
(0.006) \\
0.157^{* * *} \\
(0.008) \\
\end{array}$ & $\begin{array}{c}-0.014^{*} \\
(0.007) \\
0.269^{* * *} \\
(0.014) \\
\end{array}$ & $\begin{array}{c}0.063^{* * *} \\
(0.007) \\
0.105^{* * *} \\
(0.007)\end{array}$ & $\begin{array}{c}0.041^{* * *} \\
(0.007) \\
0.050^{* * *} \\
(0.010) \\
\end{array}$ & $\begin{array}{c}0.053^{* * *} \\
(0.008) \\
0.104^{* * *} \\
(0.008) \\
\end{array}$ & $\begin{array}{c}0.093^{* * *} \\
(0.010) \\
0.162^{* * *} \\
(0.014) \\
\end{array}$ & $\begin{array}{c}-0.018^{* * *} \\
(0.004) \\
0.138^{* * *} \\
(0.007)\end{array}$ & $\begin{array}{c}-0.008^{*} \\
(0.003) \\
0.055^{* * *} \\
(0.011) \\
\end{array}$ & $\begin{array}{c}-0.018^{* * *} \\
(0.004) \\
0.138^{* * *} \\
(0.007)\end{array}$ & $\begin{array}{c}-0.028^{* * *} \\
(0.005) \\
0.229^{* * *} \\
(0.013) \\
\end{array}$ \\
\hline \multicolumn{13}{|c|}{ (B) with personality traits } \\
\hline Detailed decomposition & $\begin{array}{c}0.016^{* *} \\
(0.006) \\
0.152^{* * *} \\
(0.008)\end{array}$ & $\begin{array}{c}0.026^{* * *} \\
(0.006) \\
0.065^{* * *} \\
(0.009)\end{array}$ & $\begin{array}{c}0.012^{+} \\
(0.007) \\
0.145^{* * *} \\
(0.008)\end{array}$ & $\begin{array}{l}0.007 \\
(0.009) \\
0.248^{* * *} \\
(0.015)\end{array}$ & $\begin{array}{c}0.069^{* * *} \\
(0.007) \\
0.099^{* * *} \\
(0.007)\end{array}$ & $\begin{array}{c}0.043^{* * *} \\
(0.008) \\
0.048^{* * *} \\
(0.010)\end{array}$ & $\begin{array}{l}0.058^{* * *} \\
(0.008) \\
0.100^{* * *} \\
(0.008)\end{array}$ & $\begin{array}{l}0.104^{* * *} \\
(0.011) \\
0.151^{* * *} \\
(0.014)\end{array}$ & $\begin{array}{c}-0.011^{*} \\
(0.005) \\
0.130^{* * *} \\
(0.007)\end{array}$ & $\begin{array}{c}-0.011^{*} \\
(0.005) \\
0.059^{* * *} \\
(0.011)\end{array}$ & $\begin{array}{c}-0.011^{*} \\
(0.005) \\
0.131^{* * *} \\
(0.007)\end{array}$ & $\begin{array}{c}-0.010 \\
(0.007) \\
0.212^{* * *} \\
(0.013)\end{array}$ \\
\hline \multicolumn{13}{|l|}{ Explained } \\
\hline Extraversion & 0.000 & 0.001 & 0.000 & 0.000 & 0.001 & 0.001 & 0.001 & 0.000 & 0.000 & $0.003^{*}$ & 0.000 & -0.002 \\
\hline Agreeableness & $0.019^{* * *}$ & $* \quad 0.010^{* * *}$ & $0.016^{* * *}$ & $0.030^{* * *}$ & $0.012^{* * *}$ & $0.006^{*}$ & $0.010^{* * *}$ & $0.020^{* * *}$ & $0.014^{* * *}$ & 0.002 & $0.013^{* * *}$ & $0.026^{* * *}$ \\
\hline Conscientiousness & $-0.005^{* * *}$ & * $-0.003^{*}$ & $-0.004^{* * *}$ & $-0.007^{* * *}$ & $-0.003^{* * *}$ & $-0.002^{+}$ & $-0.003^{* * *}$ & $-0.004^{* *}$ & $-0.007^{* * *}$ & $-0.007^{* * *}$ & $-0.006^{* * *}$ & $-0.008^{* * *}$ \\
\hline Neuroticism & 0.000 & 0.000 & 0.000 & 0.000 & 0.000 & 0.000 & 0.000 & 0.000 & 0.000 & 0.000 & 0.000 & 0.000 \\
\hline Openness & 0.000 & -0.001 & 0.000 & 0.001 & 0.000 & $-0.001^{*}$ & 0.000 & 0.000 & 0.000 & $-0.001^{* *}$ & 0.000 & 0.001 \\
\hline External locus of control & 0.000 & 0.000 & 0.000 & 0.001 & 0.000 & 0.000 & 0.000 & 0.000 & 0.001 & 0.000 & 0.001 & 0.001 \\
\hline \multicolumn{13}{|l|}{ Unexplained } \\
\hline Extraversion & 0.000 & 0.000 & 0.000 & $-0.001^{*}$ & 0.000 & 0.000 & 0.000 & 0.000 & 0.000 & 0.000 & 0.000 & $-0.001^{* *}$ \\
\hline Agreeableness & -0.001 & 0.000 & $-0.001^{*}$ & 0.000 & 0.000 & 0.000 & $-0.001^{+}$ & 0.000 & $-0.001^{+}$ & 0.000 & $-0.001^{*}$ & 0.000 \\
\hline Conscientiousness & 0.000 & -0.001 & 0.000 & 0.001 & 0.000 & -0.001 & 0.000 & 0.000 & 0.000 & -0.001 & 0.000 & $0.001^{+}$ \\
\hline Neuroticism & 0.000 & 0.000 & 0.000 & 0.000 & 0.000 & 0.000 & 0.000 & 0.000 & 0.000 & 0.000 & 0.000 & 0.000 \\
\hline Openness & 0.000 & 0.000 & 0.000 & 0.000 & 0.000 & 0.000 & 0.000 & 0.000 & 0.000 & 0.000 & 0.000 & 0.000 \\
\hline External locus of control & $0.002^{* *}$ & 0.000 & 0.001 & $0.004^{* *}$ & $0.002^{*}$ & 0.000 & 0.000 & $0.003^{*}$ & $0.002^{*}$ & 0.002 & 0.000 & $0.003^{* *}$ \\
\hline
\end{tabular}

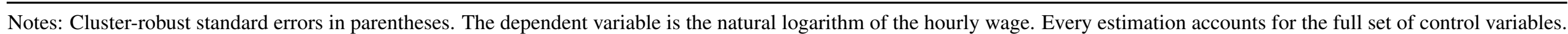
Significance levels: ${ }^{*} p<0.05,{ }^{* *} p<0.01,{ }^{* * *} p<0.001$. Sources: HILDA 2001-2015, own calculations. 
Table B6: Results of the FFL-decompositions for the UK.

\begin{tabular}{|c|c|c|c|c|c|c|c|c|c|c|c|c|}
\hline & \multicolumn{4}{|c|}{ w/o Occupation and Industry $(\mathrm{N}=68,614)$} & \multicolumn{4}{|c|}{ w/ Occupation and Industry $(\mathrm{N}=68,614)$} & \multicolumn{4}{|c|}{ Accounting for selection $(\mathrm{N}=77,930)$} \\
\hline & $\begin{array}{l}\text { Mean } \\
\text { (1) }\end{array}$ & $\begin{array}{l}10^{t h} \\
\text { Percentile } \\
\text { (2) }\end{array}$ & $\begin{array}{c}50^{t h} \\
\text { Percentile } \\
\text { (3) }\end{array}$ & $\begin{array}{c}90^{t h} \\
\text { Percentile } \\
\text { (4) }\end{array}$ & $\begin{array}{c}\text { Mean } \\
\text { (5) }\end{array}$ & $\begin{array}{l}10^{t h} \\
\text { Percentile } \\
\quad(6)\end{array}$ & $\begin{array}{l}50^{t h} \\
\text { Percentile } \\
(7)\end{array}$ & $\begin{array}{c}90^{t h} \\
\text { Percentile } \\
(8)\end{array}$ & $\begin{array}{l}\text { Mean } \\
\text { (9) }\end{array}$ & $\begin{array}{l}10^{t h} \\
\text { Percentile } \\
\quad(10)\end{array}$ & $\begin{array}{c}50^{t h} \\
\text { Percentile } \\
\text { (11) }\end{array}$ & $\begin{array}{l}90^{t h} \\
\text { Percentile } \\
\text { (12) }\end{array}$ \\
\hline Raw gap & $\begin{array}{l}0.190^{* * *} \\
(0.008)\end{array}$ & $\begin{array}{c}0.090^{* * *} \\
(0.007)\end{array}$ & $\begin{array}{l}0.224^{* * *} \\
(0.011)\end{array}$ & $\begin{array}{l}0.257^{* * *} \\
(0.016)\end{array}$ & $\begin{array}{l}0.190^{* * *} \\
(0.008)\end{array}$ & $\begin{array}{l}0.090^{* * *} \\
(0.007)\end{array}$ & $\begin{array}{l}0.224^{* * *} \\
(0.010)\end{array}$ & $\begin{array}{l}0.257^{* * *} \\
(0.015)\end{array}$ & $\begin{array}{l}0.183^{* * *} \\
(0.009)\end{array}$ & $\begin{array}{r}0.0 \\
(0.0\end{array}$ & $\begin{array}{l}7^{* * *} \\
0)\end{array}$ & $\begin{array}{r}0 . \\
(0 .\end{array}$ \\
\hline \multicolumn{13}{|c|}{ (A) without personality traits } \\
\hline Unexplained & $\begin{array}{c}0.020^{* * *} \\
(0.005) \\
0.170^{* * *} \\
(0.008)\end{array}$ & $\begin{array}{l}0.033^{* * *} \\
(0.004) \\
0.058^{* * *} \\
(0.007)\end{array}$ & $\begin{array}{c}0.019^{* *} \\
(0.007) \\
0.206^{* * *} \\
(0.009)\end{array}$ & $\begin{array}{l}0.033^{* * *} \\
(0.007) \\
0.225^{* * *} \\
(0.015)\end{array}$ & $\begin{array}{l}0.043^{* * *} \\
(0.007) \\
0.147^{* * *} \\
(0.007)\end{array}$ & $\begin{array}{c}0.036^{* * *} \\
(0.005) \\
0.054^{* * *} \\
(0.007)\end{array}$ & $\begin{array}{l}0.058^{* * *} \\
(0.008) \\
0.167^{* * *} \\
(0.009)\end{array}$ & $\begin{array}{l}0.049^{* * *} \\
(0.010) \\
0.208^{* * *} \\
(0.016)\end{array}$ & $\begin{array}{c}-0.006 \\
(0.004) \\
0.189^{* * *} \\
(0.007)\end{array}$ & $\begin{array}{c}-0.006^{*} \\
(0.003) \\
0.087^{* * *} \\
(0.007)\end{array}$ & $\begin{array}{c}-0.012^{*} \\
(0.005) \\
0.230^{* * *} \\
(0.009)\end{array}$ & $\begin{array}{c}0.010^{*} \\
(0.005) \\
0.239^{* * *} \\
(0.014)\end{array}$ \\
\hline \multicolumn{13}{|c|}{ (B) with personality traits } \\
\hline Unexplained & $\begin{array}{l}0.032^{* * *} \\
(0.006) \\
0.158^{* * *} \\
(0.008)\end{array}$ & $\begin{array}{c}0.032^{* * *} \\
(0.005) \\
0.058^{* * *} \\
(0.007)\end{array}$ & $\begin{array}{l}0.029^{* * *} \\
(0.007) \\
0.196^{* * *} \\
(0.010)\end{array}$ & $\begin{array}{l}0.055^{* * *} \\
(0.009) \\
0.202^{* * *} \\
(0.016)\end{array}$ & $\begin{array}{l}0.051^{* * *} \\
(0.007) \\
0.139^{* * *} \\
(0.008)\end{array}$ & $\begin{array}{l}0.036^{* * *} \\
(0.006) \\
0.055^{* * *} \\
(0.008)\end{array}$ & $\begin{array}{c}0.063^{* * *} \\
(0.009) \\
0.161^{* * *} \\
(0.010)\end{array}$ & $\begin{array}{l}0.067^{* * *} \\
(0.011) \\
0.191^{* * *} \\
(0.017)\end{array}$ & $\begin{array}{c}0.010^{+} \\
(0.005) \\
0.173^{* * *} \\
(0.008)\end{array}$ & $\begin{array}{c}-0.005 \\
(0.004) \\
0.086^{* * *} \\
(0.007)\end{array}$ & $\begin{array}{l}0.002 \\
(0.006) \\
0.215^{* * *} \\
(0.010)\end{array}$ & $\begin{array}{c}0.038^{* * *} \\
(0.007) \\
0.211^{* * *} \\
(0.015)\end{array}$ \\
\hline Explat & & & & & & & & & & & & \\
\hline $\begin{array}{l}\text { Extraversion } \\
\text { Agreeableness } \\
\text { Conscientiousness } \\
\text { Neuroticism } \\
\text { Openness }\end{array}$ & $\begin{array}{r}-0.003^{* *} \\
0.010^{* * *} \\
-0.005^{* * *} \\
0.012^{* * *} \\
0.001\end{array}$ & $\begin{array}{cc} & -0.002^{+} \\
* & 0.004^{* *} \\
& -0.005^{* * *} \\
& 0.005^{* * *} \\
-0.001^{*}\end{array}$ & $\begin{array}{r}-0.005^{* * *} \\
0.010^{* * *} \\
-0.005^{* * *} \\
0.010^{* * *} \\
0.002^{*}\end{array}$ & $\begin{array}{c}-0.001 \\
0.015^{* * *} \\
-0.006^{* *} \\
0.014^{* * *} \\
0.003^{* *}\end{array}$ & $\begin{array}{r}-0.002^{*} \\
0.008^{* * *} \\
-0.004^{* * *} \\
0.010^{* * *} \\
0.000\end{array}$ & $\begin{array}{c}-0.001 \\
0.003^{*} \\
-0.004^{* * *} \\
0.005^{* * *} \\
-0.001^{*}\end{array}$ & $\begin{array}{c}-0.003^{* *} \\
0.007^{* * *} \\
-0.003^{* *} \\
0.008^{* * *} \\
0.000\end{array}$ & $\begin{array}{l}0.000 \\
0.012^{* * *} \\
-0.005^{* *} \\
0.012^{* * *} \\
0.002^{*}\end{array}$ & $\begin{array}{r}-0.003^{* *} \\
0.011^{* * *} \\
-0.005^{* * *} \\
0.013^{* * *} \\
0.000\end{array}$ & $\begin{array}{c}-0.002^{*} \\
0.004^{* *} \\
-0.005^{* * *} \\
0.006^{* * *} \\
-0.002^{*}\end{array}$ & $\begin{array}{r}-0.005^{* * *} \\
0.012^{* * *} \\
-0.005^{* * *} \\
0.012^{* * *} \\
0.001^{+}\end{array}$ & $\begin{array}{c}-0.002 \\
0.015^{* * *} \\
-0.004^{*} \\
0.016^{* * *} \\
0.003^{*}\end{array}$ \\
\hline explatiea & & & & & & & & & & & & \\
\hline $\begin{array}{l}\text { Extraversion } \\
\text { Agreeableness } \\
\text { Conscientiousness } \\
\text { Neuroticism } \\
\text { Openness }\end{array}$ & $\begin{array}{l}0.000 \\
0.000^{+} \\
0.001^{+} \\
0.002^{*} \\
0.001\end{array}$ & $\begin{array}{c}0.000 \\
-0.001^{* *} \\
0.000 \\
-0.002^{* *} \\
0.001\end{array}$ & $\begin{array}{c}0.000 \\
-0.001^{* * *} \\
0.000 \\
0.001 \\
0.001\end{array}$ & $\begin{array}{l}0.000 \\
0.001 \\
0.002^{+} \\
0.006^{* *} \\
0.001\end{array}$ & $\begin{array}{c}0.000 \\
-0.001^{* *} \\
0.001^{*} \\
0.002^{*} \\
-0.001\end{array}$ & $\begin{array}{c}0.000 \\
0.000^{+} \\
0.000 \\
-0.002^{* *} \\
0.000\end{array}$ & $\begin{array}{c}0.000 \\
-0.002^{* * *} \\
0.000 \\
0.001 \\
-0.001\end{array}$ & $\begin{array}{l}0.000 \\
0.000 \\
0.002^{*} \\
0.006^{* *} \\
0.000\end{array}$ & $\begin{array}{c}0.000 \\
-0.001^{* *} \\
0.001^{+} \\
0.001 \\
0.001\end{array}$ & $\begin{array}{l}0.000 \\
-0.001^{* * *} \\
0.000 \\
-0.003^{* * *} \\
0.000\end{array}$ & $\begin{array}{c}0.000 \\
-0.001^{* * *} \\
0.001 \\
0.000 \\
0.001\end{array}$ & $\begin{array}{l}0.000 \\
0.000 \\
0.001 \\
0.006^{* *} \\
0.001\end{array}$ \\
\hline
\end{tabular}

Notes: Cluster-robust standard errors in parentheses. The dependent variable is the natural logarithm of the hourly wage. Every estimation accounts for the full set of control variables. Significance levels: ${ }^{*} p<0.05,{ }^{* *} p<0.01,{ }^{* * *} p<0.001$. Sources: HILDA 2001-2015, own calculations. 

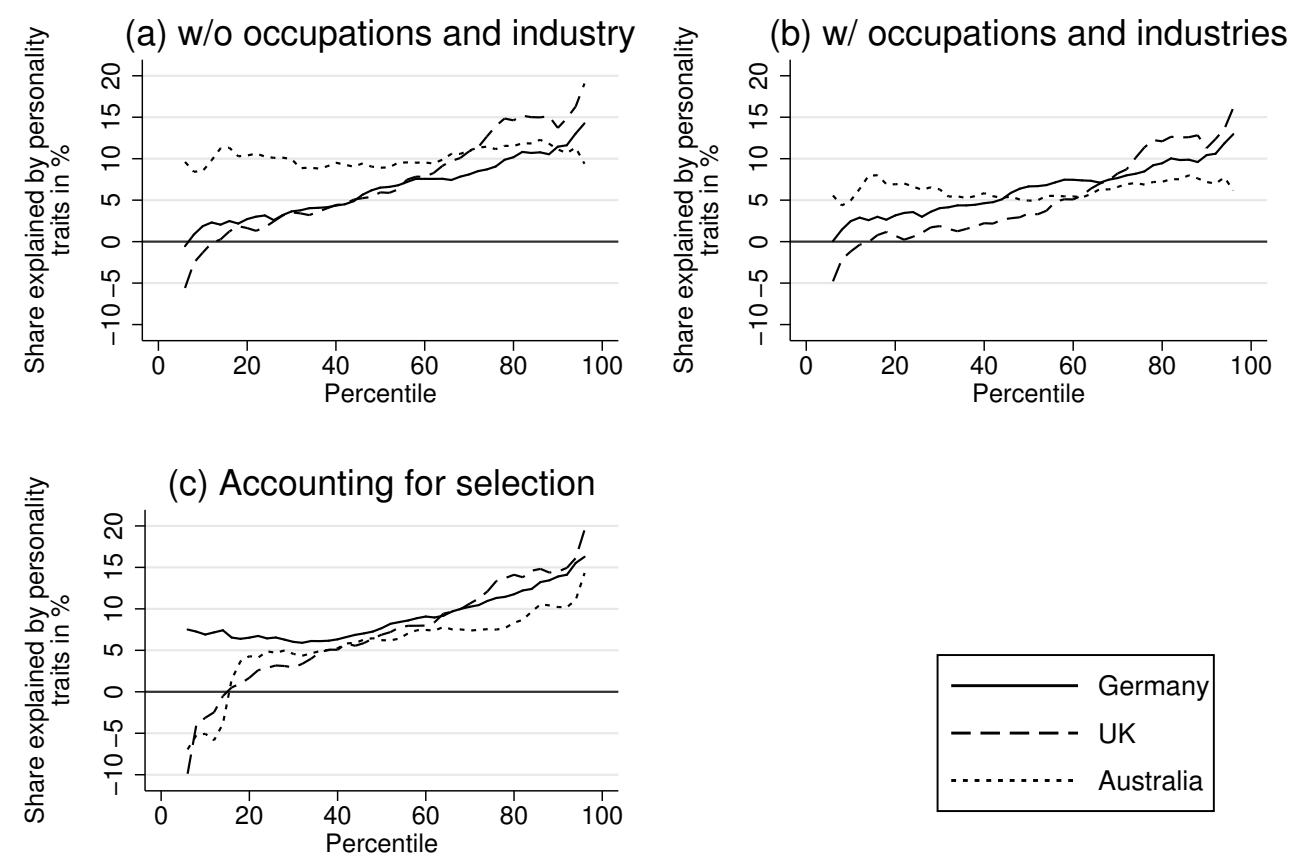

Sources: SOEP v32 1991-2015; UKHLS 2009-2015; HILDA 2001-2015; own calculations.

Figure B5: The relative share of wage gaps explained by personality traits. 